\title{
Paleoproterozoic evolution of the Guiana Shield in Suriname: A revised model
}

\author{
S.B. Kroonenberg ${ }^{1, *}$, E.W.F. de Roever ${ }^{2}$, L.M. Fraga ${ }^{3}$, N.J. Reis ${ }^{4}$, T. Faraco ${ }^{5}$, J.-M. Lafon ${ }^{6}$, \\ U. Cordani ${ }^{7} \&$ T.E. Wong ${ }^{8}$
}

1 Delft University of Technology, Department of Geoscience and Engineering, P.0. Box 5048, 2600 GA Delft, the Netherlands

2 VU University Amsterdam, Faculty of Earth and Life Sciences, De Boelelaan 1085-1087, 1081 HV Amsterdam, the Netherlands

3 CPRM - Serviço Geológico do Brasil, Departamento de Geologia - DEGE0/ERJ, Avenida Pasteur, 404 - Urca, $22290-240$ Rio de Janeiro, RJ, Brazil

4 CPRM - Serviço Geológico do Brasil, Av. André Araújo 2160 - Aleixo, Manaus, AM, Brazil

5 CPRM - Serviço Geológico do Brasil, Avenida Dr. Freitas, 3645 - Bairro do Marco, Belém, PA, Brazil

6 Universidade Federal do Pará, Instituto de Geociências, Campus Universitário do Guamá, Rua Augusto Correa No01, Belém, PA, Brazil

7 Universidade de São Paulo, Instituto de Geociências, Rua do Lago 562, Cidade Universitaria, CEP 05508-080, São Paulo, SP, Brazil

8 Universiteit van Suriname, Faculteit Technische Wetenschappen, Leysweg 86, P.0. Box 9212, Paramaribo, Suriname

* Corresponding author. Email: s.b.kroonenberg@tudelft.nl

Manuscript received: 3 November 2015, accepted: 18 March 2016

\section{Abstract}

The Proterozoic basement of Suriname consists of a greenstone-tonalite-trondhjemite-granodiorite belt in the northeast of the country, two highgrade belts in the northwest and southwest, respectively, and a large granitoid-felsic volcanic terrain in the central part of the country, punctuated by numerous gabbroic intrusions. The basement is overlain by the subhorizontal Proterozoic Roraima sandstone formation and transected by two Proterozoic and one Jurassic dolerite dyke swarms. Late Proterozoic mylonitisation affected large parts of the basement. Almost 50 new U-Pb and $\mathrm{Pb}-\mathrm{Pb}$ zircon ages and geochemical data have been obtained in Suriname, and much new data are also available from the neighbouring countries. This has led to a considerable revision of the geological evolution of the basement. The main orogenic event is the Trans-Amazonian Orogeny, resulting from southwards subduction and later collision between the Guiana Shield and the West African Craton. The first phase, between 2.18 and $2.09 \mathrm{Ga}$, shows ocean floor magmatism, volcanic arc development, sedimentation, metamorphism, anatexis and plutonism in the Marowijne Greenstone Belt and the adjacent older granites and gneisses. The second phase encompasses the evolution of the Bakhuis Granulite Belt and Coeroeni Gneiss Belt through rift-type basin formation, volcanism, sedimentation and, between 2.07 and $2.05 \mathrm{Ga}$, high-grade metamorphism. The third phase, between 1.99 and $1.95 \mathrm{Ga}$, is characterised by renewed high-grade metamorphism in the Bakhuis and Coeroeni belts along an anticlockwise cooling path, and ignimbritic volcanism and extensive and varied intrusive magmatism in the western half of the country. An alternative scenario is also discussed, implying an origin of the Coeroeni Gneiss Belt as an active continental margin, recording northwards subduction and finally collision between a magmatic arc in the south and an older northern continent. The Grenvillian collision between Laurentia and Amazonia around 1.2-1.0 Ga caused widespread mylonitisation and mica age resetting in the basement.

Keywords: Trans-Amazonian Orogeny, SHRIMP U-Pb geochronology, Guiana-Africa collision

\section{Introduction}

The Guiana Shield forms the northern part of the Amazonian Craton, the core of the South American continent, and is separated from its southern counterpart, the Central Brazil- ian Shield, by the Amazon-Solimões basin (Fig. 1). It is one of the least investigated Precambrian shields in the world. Geological research is hampered by its inaccessibility due to the virtually continuous rainforest cover and deep weathering, but also due to the varying state of geological activity in the 


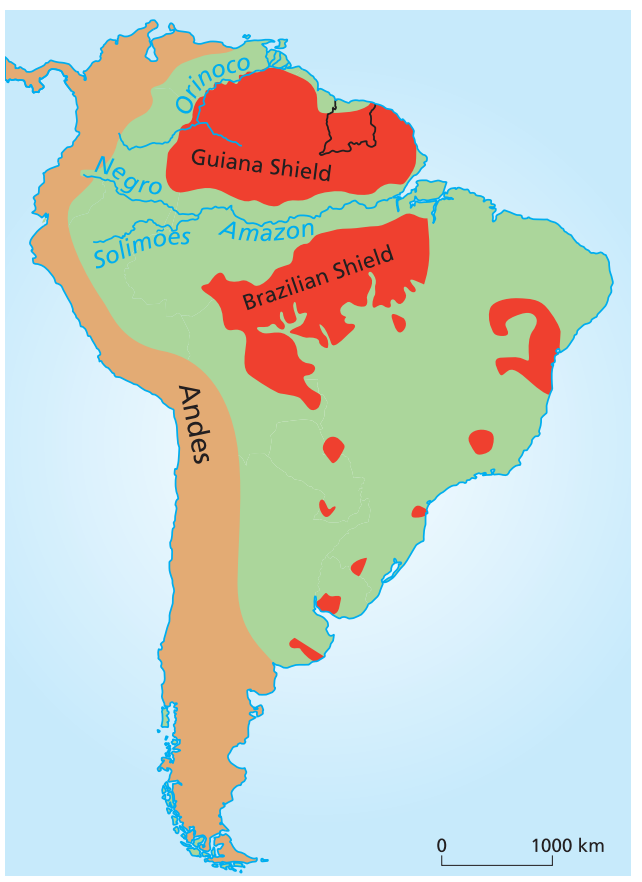

Fig. 1. The Guiana Shield and the Central Brazilian Shield together form the Amazonian Craton (modified after Cordani \& Sato, 1999).

constituting countries: Brazil, Colombia, French Guiana, Guyana, Suriname and Venezuela. Earlier reviews of the Amazonian Craton and the Guiana Shield in particular are given by Gibbs \& Barron (1993), Tassinari \& Macambira (1999), Tassinari et al. (2000), Santos et al. (2000, 2006), Delor et al. (2003a,b), Cordani \& Teixeira (2007), Fraga et al. (2009a) and Kroonenberg \& De Roever (2010).

Two major Archean nuclei have been recognised in the Guiana Shield: the Venezuelan Imataca block in the west and the Amapá block in the eastern part (Fig. 2). The centraleastern part of the shield shows three major, roughly WNWESE stretching geotectonic units. The northernmost part of the shield is occupied by a prominent Paleoproterozoic greenstonetonalite-trondhjemite-granodiorite (TTG) belt (2.26-2.07 Ga), generally attributed to the Trans-Amazonian Orogeny coined by Hurley et al. (1967), now considered to record the convergence and eventual collision between the Archean nuclei of the Amazonian Craton and the West African Craton between 2.2 and 1.9 Ga (Vanderhaeghe et al., 1998, Voicu et al., 2001; Delor et al., 2003a,b; Nomade et al., 2003; Cordani \& Teixeira, 2007; Bispo-Santos et al., 2014). South of the greenstone belt and roughly parallel to it, there is a WNW-ESE stretching belt of felsic metavolcanics intruded by shallow granites (1.99-1.96 $\mathrm{Ga}$ ). This belt is in turn bounded on the southern side by a discontinuous 2.07-1.98 Ga belt of high-grade rocks, the Central Guiana Belt, consisting of two parts, the sinuous and discontinuous Cauarane-Coeroeni Gneiss Belt stretching roughly NWSE/NE-SW/NW-SE across northern Brazil, southern Guyana and southwest Suriname, and the NE-SW stretching Bakhuis Gran- ulite Belt in northwestern Suriname. These units are overlain by an up to $3000 \mathrm{~m}$ thick subhorizontal sequence of sandstones and conglomerates with tuff intercalations, the $\sim 1.87 \mathrm{Ga}$ Roraima Supergroup, generally considered as the molasse of the Trans-Amazonian Orogeny. All above-mentioned units are intruded by large volumes of the Paleoproterozoic Avanavero dolerite dykes and sills of $1.79 \mathrm{Ga}$. The southernmost part of the central Guiana Shield is occupied by a younger belt of felsic volcanics and related granitic intrusions, the Iricoumé-Jatapu belt (1.89-1.81 Ga, Reis et al., 2003), also sometimes called Uatumã, although this term has been used in different ways in the past (Montalvão, 1975; Klein et al., 2012).

The westernmost part of the Guiana Shield is occupied by the Río Negro belt, the youngest belt of high-grade rocks in the shield (1.86-1.72 Ga, Fig. 2), attributed to continental accretion after cratonisation of the remainder of the shield (Tassinari, 1981; Tassinari et al., 1996; Tassinari \& Macambira, 1999; Santos et al., 2000, 2006; Cordani et al., 2000; Cordani \& Teixeira, 2007; Rodríguez et al., 2011; Kroonenberg \& Reeves, 2012; Almeida et al., 2013; Kroonenberg, 2014). The Rio Negro belt is intruded by - partly rapakivi-type - Mesoproterozoic plutons and unconformably covered with folded sandstones.

Widely differing concepts have been proposed about the general structure and geodynamic history of the shield, as will be discussed at the end of this paper. The discussion is obscured by the fact that many older age data still hinge on $\mathrm{Rb}-\mathrm{Sr}$ isochrons, now considered to give usually too generalised and too low regional ages with very large error margins. They are no longer considered to give crystallisation ages, but rather indicate the timing of relevant episodes of Sr isotopic homogenisation related to medium- to high-grade metamorphic episodes. Modern geochronological work requires $\mathrm{U}-\mathrm{Pb}$ measurements, by SHRIMP, LA-ICP-MS, or TIMS, which produce more precise data on the timing of crystallisation and metamorphism of rocks. $\mathrm{Sm}-\mathrm{Nd}$ model ages give insight into the type of regional tectonic processes (e.g. intraplate- or subduction-related, accretionary or collisional, juvenile or reworked). Finally, K-Ar ages, especially of micas, are related to the final cooling of the region, usually with respect to the principal episode of cratonisation or to some episodes of major intraplate crustal heating above 350$400^{\circ} \mathrm{C}$. Much modern zircon U-Pb and Sm-Nd geochronological work has been done in the Brazilian part of the Guiana Shield (e.g. Avelar et al., 2003; Rosa-Costa et al., 2003, 2006 in Amapá; Reis et al., 2003; Fraga et al., 2009b in Roraima State; Cordani et al., 2000, 2010) and in French Guiana (Delor et al., 2003a,b), but in the other countries only incidental data are available.

In Suriname, a lot of research has been done in the 1970s for the production of the 1:500,000 geological map of the country (GMD, 1977; Priem et al., 1971, 1973; Bosma et al., 1983, 1984; De Vletter, 1984; De Vletter et al., 1998). In its time, it was one of the most detailed and well-documented maps of the Guiana Shield, based on a complete coverage of 1:40,000 aerial photographs (0'Herne, 1969b), aerogeophysical data, over 


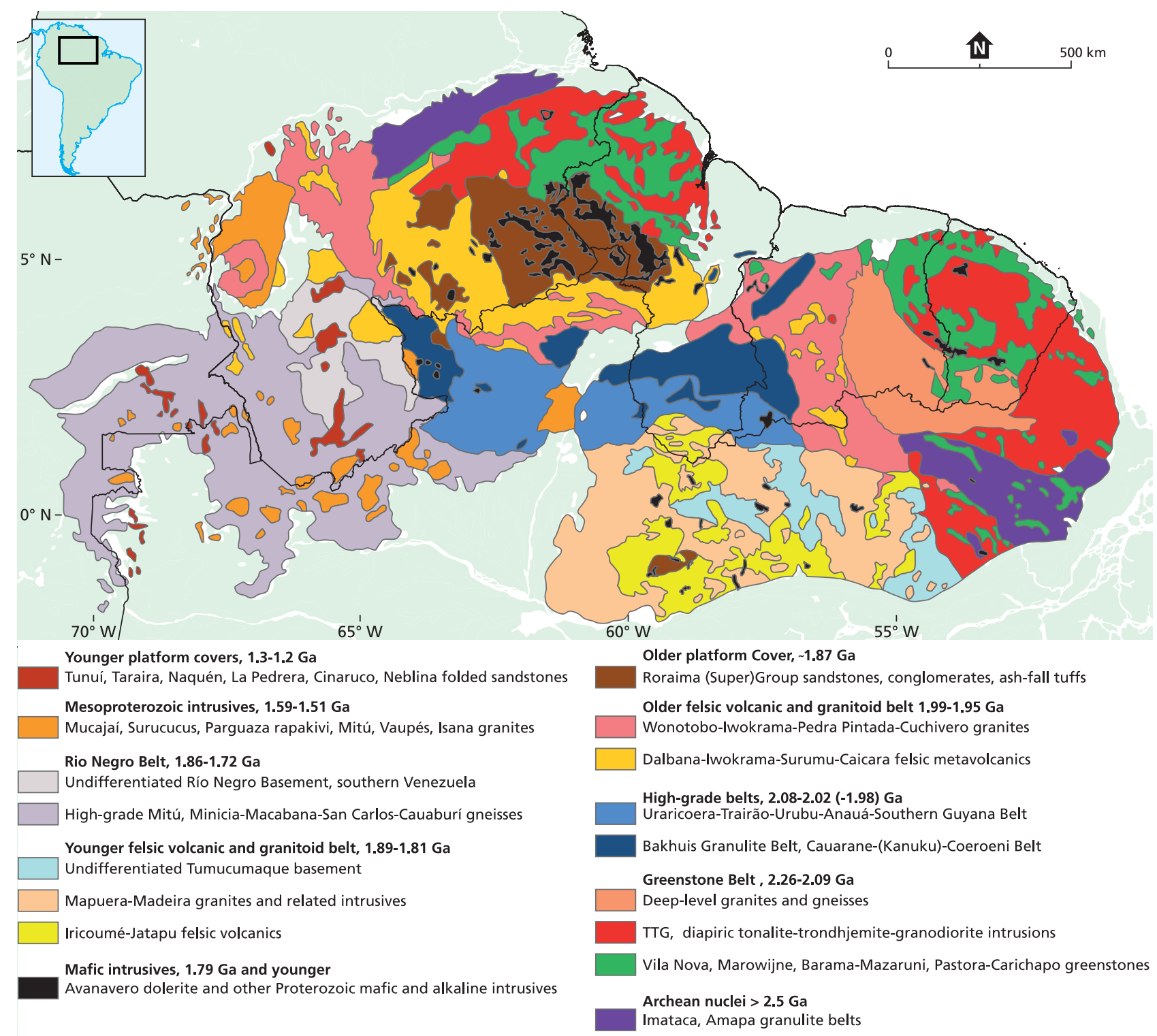

Fig. 2. Simplified geological map of the Guiana Shield, compiled after various sources.

100,000 rock samples collected during over 40 years of field surveys, over 900 drill cores with a total depth of over $44 \mathrm{~km}$, geochronological analyses of over 300 rock and mineral samples (Priem et al., 1971, 1973, 1978) and many local geological and geochemical surveys of areas with mineral potentials (see reviews by Bosma et al., 1983 and De Vletter, 1984).

The map legend was based mainly on lithology and geochronology, and map units were identified with numbers 1-47 from young to old. The plethora of old formation names was strongly reduced. Oddly enough some common formation names were maintained by Bosma et al. (1983) and abolished by the same authors in 1984 when the Explanatory Note of the map was finally published by the editor at that time (De Vletter, 1984). In hindsight, the shortcomings of this map were that after all too little use was made of structural information and of aerial photographs and LANDSAT data to map the dif- ferent lithologies. Also no serious attempt was made to come to a geotectonic reconstruction of the main Trans-Amazonian Orogeny except for an unpublished earlier manuscript by Maas (1979).

Since then, some modern work has been done on the goldbearing part of the greenstone belt (Daoust et al., 2011), and on magmatism and UHT metamorphism in the Bakhuis Mountains (De Roever et al., 2003a; Klaver et al., 2015, 2016). Now, in the framework of joint projects of the University of Suriname and the Geological and Mining Service of Suriname with the Geological Survey of Brazil (CPRM in Brazil), the Associação Brasileira de Cooperação $(\mathrm{ABC})$ and the Commission for the Geological Map of South America (Gómez Tapias, 2014) new geochronological data have been obtained for many rock units. This paper summarises the revised stratigraphy of the basement and its geological evolution based on new zircon $\mathrm{U}-\mathrm{Pb}$ and $\mathrm{Pb}-\mathrm{Pb}$ data 


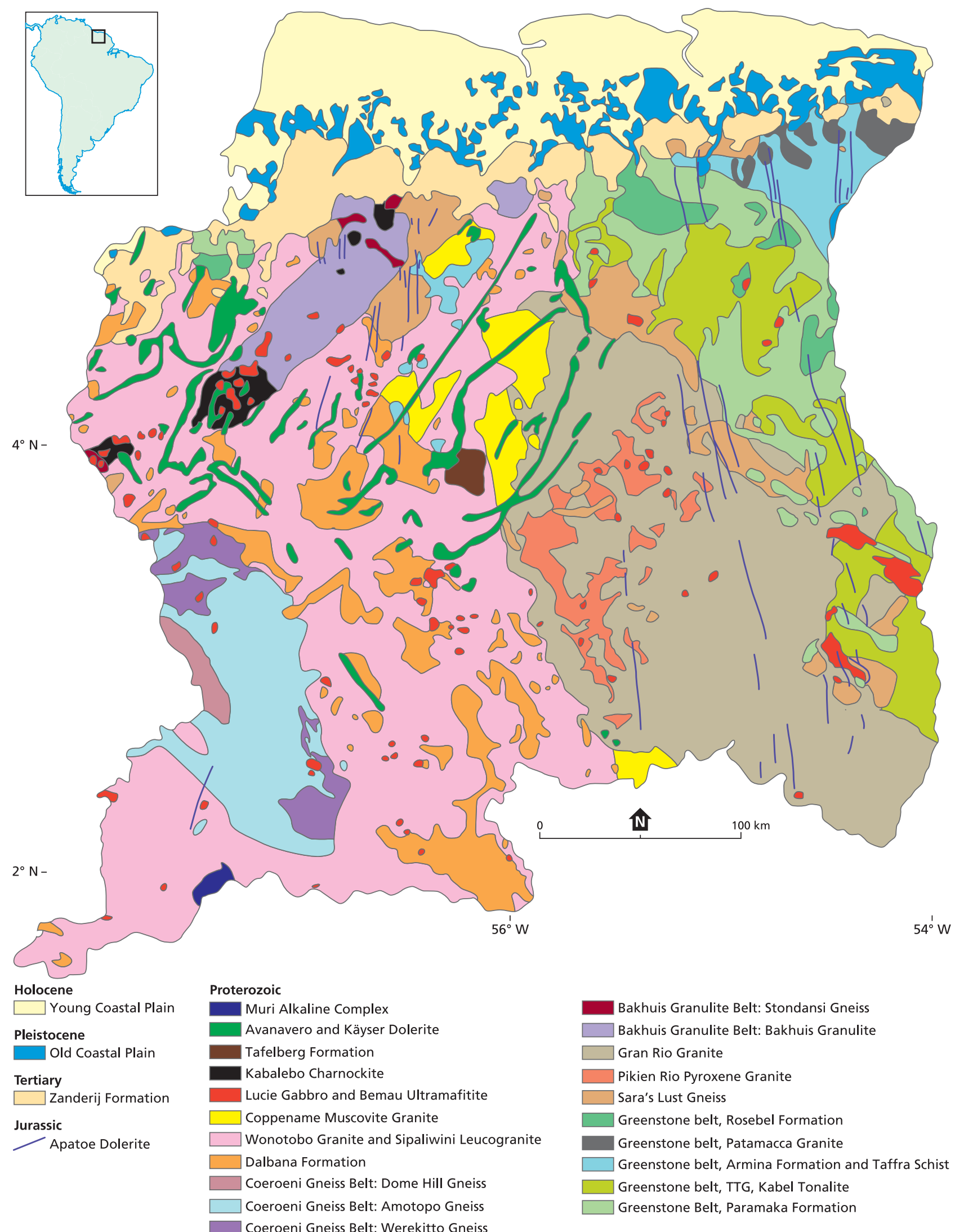

Fig. 3. Simplified geological map of Suriname, according to modern data. 


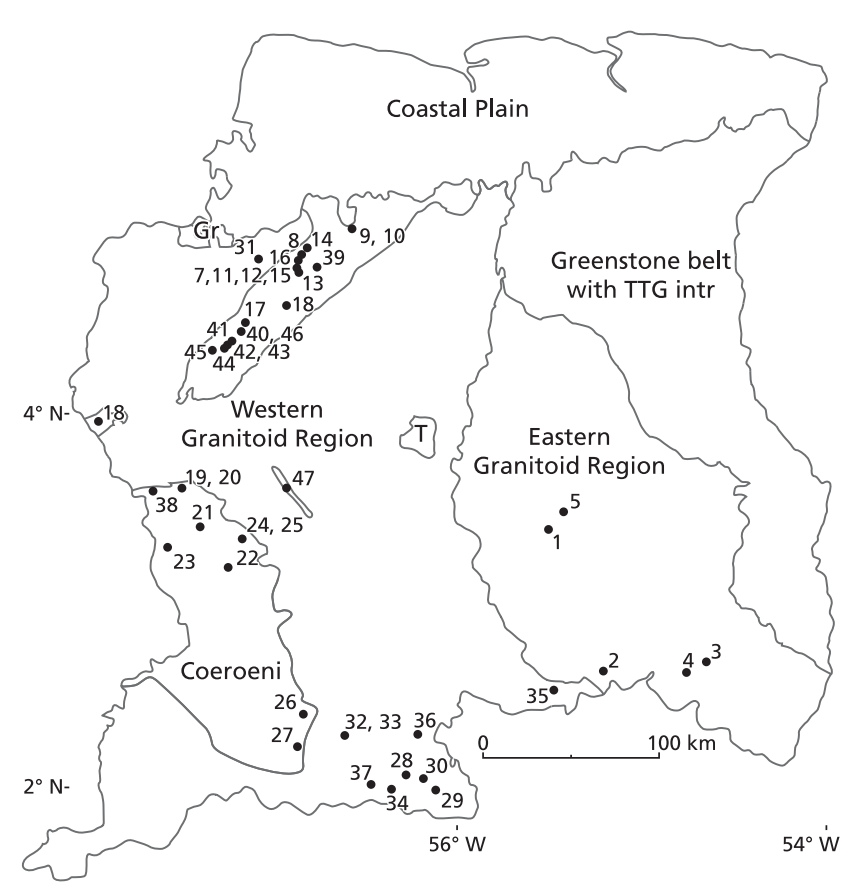

Fig. 4. Locations of new radiometrically dated samples (numbers refer to Tables 2-5).

from Suriname and recently published geochronological data from French Guiana and Brazil (Figs 3 and 4, Table 1). Only the radiometric ages of the rocks are presented here, the analytical details of the geochronology will be given in a forthcoming paper. Emphasis is on new data and recent references, older references can be found in earlier reviews (Bosma et al., 1983, 1984; De Vletter, 1984; De Vletter et al., 1998). Nevertheless, there has been no systematic remapping of the basement since the 1970s, because of the absence of modern aerogeophysical data, so that only the age of the rock units on the geological map change, not their outcrop contours. This is a huge task for the future and therefore the present paper is just an intermediate step, meant as work in progress.

\section{Outline of the geology of Suriname}

The Proterozoic basement of Suriname consists of three metamorphic belts, the low-grade Marowijne Greenstone Belt in the northeast and the high-grade Bakhuis Granulite Belt and Coeroeni Gneiss Belt in the northwest and southwest, respectively, separated in the central part of the country by a large area with various types of granitoid rocks and felsic metavolcanic rocks. The basement is overlain by the Proterozoic Tafelberg Formation, a sandstone remnant of the Roraima Supergroup, and transected by Proterozoic and Early Jurassic dolerite dykes (Fig. 3).

In the 1977 concept, the Bakhuis Granulite Belt was considered to be the oldest, possibly Archean, rock unit, followed by the Coeroeni Gneiss Belt, whereas the Marowijne Greenstone
Belt was thought to be a younger development (GMD, 1977; Bosma et al., 1983, 1984; De Vletter, 1984; De Vletter et al., 1998). Moreover, all granites were thought to belong to a single magmatic suite, the Gran Rio Granite, a concept already introduced by the grand old man of Surinam geology, IJzerman (1931). These appreciations were based essentially on $\mathrm{Rb}-\mathrm{Sr}$ and K-Ar geochronology (Priem et al., 1971, 1973) and formed the base of the order of rock units in the legend. However, the recent $\mathrm{U}-\mathrm{Pb}$ and $\mathrm{Pb}-\mathrm{Pb}$ zircon geochronological data have thoroughly upset this scheme, and made us return in part to older concepts, as already foreseen by De Vletter (1984) and De Vletter et al. (1998).

In order to facilitate the discussion, some of the older formation names have been reintroduced below, and some new names had to be coined because several rock units mapped on lithological grounds as a single entry in 1977 now are known to comprise two different units more than 100 million years apart in age. For the same reason, the numbers used to identify rock units on the 1977 map have been abolished here. They have only been maintained in Table 1 for easy reference to older literature.

We present here a threefold subdivision of the TransAmazonian Orogeny for Suriname, slightly different from that distinguished in French Guiana by Delor et al. (2003a,b): (1) an early phase between $2.18 \mathrm{Ga}$ and $2.09 \mathrm{Ga}$ leading to the formation of the greenstone belt and associated plutonic rocks in the eastern half of the country, (2) a second one in the high-grade Bakhuis and Coeroeni belts resulting in sedimentation and volcanism, probably in a rift-like setting, followed by amphiboliteto granulite-facies metamorphism between 2.07 and $2.05 \mathrm{Ga}$, and (3) a third one around $1.98 \mathrm{Ga}$, evidenced by widespread felsic volcanism and comagmatic subvolcanic magmatism in large parts of western Suriname, accompanied by simultaneous punctual mafic to ultramafic intrusions, as well as deepseated intrusions of charnockite and anorthosite in the Bakhuis Granulite Belt. At the same time renewed high-grade metamorphism at higher pressures affected both high-grade belts. An alternative scenario implying subduction from the south and a continental collision along the Cauarane-Coeroeni Belt is also discussed.

\section{Marowijne Greenstone Belt}

The Marowijne Greenstone Belt in Suriname forms part of a large Paleoproterozoic greenstone belt stretching over a distance of $1500 \mathrm{~km}$ along the whole northern coast of the Guiana Shield from Venezuela to the Amapá state in Brazil (Figs 2 and 3, Table 1; Gibbs, 1980; Bosma et al., 1983; Gibbs \& Barron, 1993; Voicu et al., 2001; Delor et al., 2003a,b; Rosa-Costa et al., 2009). Geographically, it can be subdivided into two parts, east and west of the Bakhuis horst (Gibbs \& Barron, 1993; De Vletter et al., 1998; Delor et al., 2003a,b). Its eastern branch fans out 
Table 1. Stratigraphy and sequence of events in the suriname basement

\begin{tabular}{|c|c|c|c|c|c|c|c|}
\hline \multicolumn{2}{|l|}{ Epoch } & Main unit & Subdivision & 1977 nr. & Rocks & Age & Events \\
\hline \multicolumn{2}{|l|}{ Jurassic } & Apatoe Dolerite & & 15 & Pigeonite dolerite & $196.0 \pm 1.7 \mathrm{Ma}$ & \\
\hline & & mans & & & & 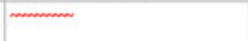 & \\
\hline \multirow{4}{*}{\multicolumn{2}{|c|}{$\begin{array}{l}\text { Meso- } \\
\text { proterozoic }\end{array}$}} & Muri Alkaline Complex & & 20 & Alkali syenite, carbonatite (?) & $\sim 1090 \mathrm{Ma}$ & \\
\hline & & Nickerie Mylonite & & 16 & Mylonite & $\sim 1200 \mathrm{Ma}$ & \\
\hline & & & & & & $m$ & \\
\hline & & Käyser Dolerite & & 17 & Olivine dolerite & $\sim 1500 \mathrm{Ma}$ & \\
\hline \multirow{8}{*}{ Paleo- } & & Avanavero Dolerite & & 18 & Hypersthene dolerite & $1787 \mathrm{Ma}(\mathrm{BR})$ & \\
\hline & & Tafelberg Fmn & & 19 & Sandstone, conglomerate, volc. ash & $1873 \mathrm{Ma}(\mathrm{BR})$ & \\
\hline & $\begin{array}{l}c \\
0\end{array}$ & 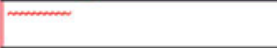 & & & & 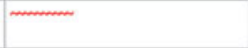 & \\
\hline & $\overline{-}$ & \multirow{5}{*}{ Younger intrusives } & Coppename Muscovite Granite & 26 & Muscovite granite & $1974 \pm 2 \mathrm{Ma}$ & \multirow{11}{*}{ 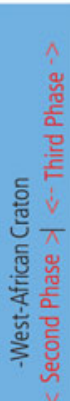 } \\
\hline & $\bar{n}$ & & Lucie Gabbro & 31 & (Meta)gabbro, ultramafitite & $1985 \pm 2 \mathrm{Ma}$ & \\
\hline & $\tilde{0}$ & & & 25 & Charnockite, pyroxene granite & 1988.5 (avg $N=5$ ) & \\
\hline & $=$ & & Wonotobo Granite & 23 & Biotite granite & $1980 \pm 6 \mathrm{Ma}$ & \\
\hline & & & Sipaliwini Leucogranite & $20,21,22$ & Leuco-, fine-gr., granophyric granite & $1980 \pm 4 \mathrm{Ma}$ & \\
\hline \multirow[t]{2}{*}{ protero } & & Younger felsic volcanites & Dalbana Formation & 29,30 & (Meta)rhyolite, dacite & $1987 \pm 4 \mathrm{Ma}$ & \\
\hline & & Coeroeni Gneiss Belt & Werekitto Gneiss & 43 & Quartzofeldspathic gneiss & $1984 \pm 5,1994 \pm 4 \mathrm{Ma}$ & \\
\hline \multirow[t]{18}{*}{ zoic } & & (Coeroeni Group) & Amotopo Gneiss & 45 & Amphibolite-facies metapelite & $2053 \pm 9,1986 \pm 15$ & \\
\hline & & & Dome Hill Gneiss & 46 & Granulite-facies metapelite & $2079 \pm 17$ & \\
\hline & & Bakhuis Granulite Belt & Bakhuis Granulite & 47 & Intermediate-mafic granulite & $2065 \pm 2 \mathrm{Ma}$ & \\
\hline & & (Falawatra Group) & Stondansi Gneiss & 46 & Metapelitic granulite & $2072 \pm 4,2055 \pm 3 \mathrm{Ma}$ & \\
\hline & & Older granites & Gran Rio Granite & 24 & Biotite granite & 2094 (avg N=5) & \multirow{14}{*}{ 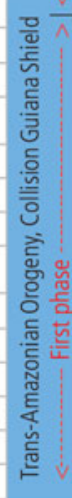 } \\
\hline & $c$ & & Pikien Rio Pyroxene Granite & 25 & Pyroxene granite & $2097 \pm 1 \mathrm{Ma}$ & \\
\hline & 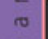 & \multirow{12}{*}{$\begin{array}{l}\text { Marowijne Greenstone Belt } \\
\text { (Marowijne Group) }\end{array}$} & Rosebel Formation & 32 & Quartz sandstone, conglomerate & $<2115 \mathrm{Ma}$ ? (FG) & \\
\hline & $\bar{v}$ & & & & & & \\
\hline & $>$ & & Patamacca Granite & 27 & Two-mica granite & $2060 \pm 4(F G)$ & \\
\hline & ᄃ & & Taffra Schist & 34 & Staurolite schist & & \\
\hline & $\simeq$ & & Armina Formation & 33 & Metagreywacke, phyllite & $<2127 \mathrm{Ma}$ ?(FG) & \\
\hline & & & & & & & \\
\hline & & & Sara's Lust Gneiss & 43,44 & Migmatitic gneiss & 2155-2165 Ma (FG) & \\
\hline & & & Kabel Tonalite & 28 & Tonalite, trondhjemite, granodiorite & $2180-2130 \mathrm{Ma}$ (FG) & \\
\hline & & & Paramaka Formation & $35-36$ & Phyllite, metachert etc & & \\
\hline & & & Paramaka Formation & $37-38$ & Metaquartzandesite, metadacite etc & $2137 \pm 6,2156 \mathrm{GMa}(\mathrm{FG})$ & \\
\hline & & & Bemau Ultramafitite & $41,42,31$ & (Meta)gabbro, meta-ultramafitite & 2147-2144 Ma (FG) & \\
\hline & & & Paramaka Formation & $39-40$ & Metabasalt, amphibolite & & \\
\hline
\end{tabular}

eastwards from the Coppename area in central-north Suriname to encompass large areas along the Marowijne River. Further east in French Guiana it splits into two branches, separated by a large TTG-granitoid terrain, while still further east in Amapá State in Brazil the two branches come together again. The western branch of the greenstone belt west of the Bakhuis Mountains starts in northwestern Suriname in the Avanavero-Matapi area, and continues into Guyana across the Mesozoic Takutu Graben (Fig. 2).

The main northeastern part of the Marowijne Greenstone Belt shows a broad asymmetrical synclinorial structure, with its oldest rock units, the Paramaka Formation greenschist-facies metabasalts and associated rocks, on the outer, southwestern side, and the younger, mainly metaturbiditic Armina Formation in the northeastern core of the synclinorium. The Paramaka Formation is intruded by large ellipsoid diapiric TTG bodies and small mafic to ultramafic plutons, now partly metamor- phosed (Veenstra, 1983). Smaller plutons of two-mica granite intrude the Armina Formation in the northeastern corner of the Marowijne Greenstone belt. The Paramaka and Armina Formations are unconformably overlain by a more mature metasandstone formation, the Rosebel Formation. The total thickness of the greenstone belt sequences is estimated by Gibbs \& Barron (1993) to be up to 8-10 km. Gold mineralisation is largely bound to quartz veins formed in late deformation stages (Daoust et al., 2011). On both its southwestern and northern sides the greenstone belt is bordered by a belt of migmatitic gneisses (Sara's Lust Gneiss). Modern zircon geochronological data from Suriname are still lacking, therefore we rely on the high-quality age data from the continuation of the greenstone belt in French Guiana and Amapá. All correlated rocks dated so far in the French part and Amapá have formed in an interval between 2.26 and 2.10 Ma during the Trans-Amazonian Orogeny (Milési et al., 1995; 
Avelar et al., 2002; Delor et al., 2003a,b; Rosa-Costa et al., 2006, 2009).

The Paramaka, Armina and Rosebel Formations were formerly described as a supracrustal series forming part of the Marowijne Group (GMD, 1977; Bosma et al., 1983), later redefined by Gibbs \& Barron (1993) and De Vletter et al. (1998) as the Marowijne Supergroup. We now prefer to abandon the designation Marowijne (Super)Group, as it is clear from field and geochronological data that they do not form a continuous sequence. Ultramafic and TTG plutonism occurred simultaneously with the Paramaka but before the deposition of the Armina, and the Rosebel Formation overlies both the Paramaka and the Armina Formation unconformably. The 1977 concept was based on the fact that all granitoid rocks, including the TTG bodies, were thought to be younger than the Marowijne Group because they all fitted the $1874 \pm 40 \mathrm{Rb}-\mathrm{Sr}$ isochron of Priem et al. (1971). Our new scheme returns to older schemes by, for example, D'Audretsch (1957; see also the 1966 scheme in 0'Herne, 1969a and discussion in De Vletter et al., 1998) and in French Guyana by Choubert (1960, 1974; see Table 1). We retain the name Marowijne for the geotectonic unit Marowijne Greenstone Belt, in symphony with the recently defined Bakhuis Granulite Belt (De Roever et al., 2003a; Klaver et al., 2015a). The Marowijne Greenstone Belt supracrustal rocks shows tight to isoclinal folding with horizontal to steeply dipping fold axes.

\section{Paramaka Formation}

The Paramaka Formation consists of a series of lavas, tuffs and volcaniclastic sediments with some intercalated chemical sediments, all metamorphosed in the greenschist facies and, close to TTG intrusions, to the amphibolite facies (Bosma et al., 1983, 1984; Veenstra, 1983). Metabasalts with pillow structures were observed in the Saramacca area and in the Rosebel Gold Mine (Fig. 5) and show by their low-K tholeiïtic chemistry ocean floor probably back-arc affinities (Veenstra, 1983; Daoust et al., 2011). The metabasalts from Royal Hill in the Rosebel Gold Mine have flat chondrite-normalised REE patterns enriched in average around $10 \times$ to $25 \times$ chondrite (Veenstra, 1983; Daoust et al., 2011). $\mathrm{La}_{\mathrm{N}} / \mathrm{Yb}_{\mathrm{N}}$ ratios vary between 1.70 and 2.10 , indicating a very low fractionation of REE (Daoust et al., 2011). These form probably the base of the sequence, although their lower contact has not been observed. Higher up, more differentiated meta-andesites, metadacites, metarhyolites and associated tuffs occur with a calc-alkaline signature. Intercalated phyllites, and carbonaceous and ferruginous cherts increase towards the top of the sequence. Meta-andesites are slightly enriched in LREE, the rhyolites much stronger, with chondrite-normalised values for LREE between $97 \times$ and $187 \times$ chondrite and $\mathrm{La}_{\mathrm{N}} / \mathrm{Yb}_{\mathrm{N}}$ values that vary between 8.98 and 21.14 (Daoust et al., 2011). This shows that volcanism in the Paramaka Formation in and near the Rosebel area recorded a change in tectonic context from a back-arc extensional basin environment to a subductiondominated environment (Veenstra, 1983; Daoust et al., 2011).

Greenschist-facies metamorphism converted the basalts into massive actinolite-epidote-chlorite-sodic plagioclase greenstones with commonly relict porphyritic, amygdaloidal and fluidal textures, as well as amphibole schists. Andesites and rhyolites are metamorphosed into chlorite and sericite schists. Amphibolite-facies equivalents, commonly found around the TTG plutons, include common amphibolites, clinopyroxenegarnet-bearing metabasalts, banded ironstones (itabirites; Bosma, 1973a), spessartine quartzites (gondites; Holtrop, 1962; Bosma, 1969), schists with chloritoid, paragonite, staurolite, kyanite and garnet, and some calcsilicate rocks (Bosma et al., 1983).

In southern French Guiana two zircon ages have been obtained from metaquartzandesites of the same formation of 2156 $\pm 6 \mathrm{Ma}$ (U-Pb ion microprobe) and $2137 \pm 6 \mathrm{Ma}$ (Pb evaporation) (Delor et al., 2003a). No reliable direct age data are available for the oceanic metabasites at the base.

In northwestern Suriname, west of the Bakhuis horst, similar rocks reappear, the first vestige of the western branch of the greenstone belt that continues into Guyana across the Takutu graben. Loemban Tobing (1969) refers to them as spilite-quartzkeratophyre suite, and calls them Matapi Formation. Their description resembles that of the Paramaka metabasalts and related metavolcanics, while chemical analyses have shown that the designation 'spilite' is incorrect (De Vletter et al., 1998).

\section{Bemau Ultramafitite}

Closely associated with the Paramaka Formation ultramaficmafic intrusive bodies occur, such as the Bemau ultramafic complex in the Saramacca area, described in great detail by Veenstra (1983). Similar bodies are found in the De Goeje Mountains in southeast Suriname, and the name De Goeje Gabbro was formerly used to indicate all punctual gabbroic and ultramafic bodies in Suriname (Bosma et al., 1983, 1984; De Vletter, 1984). However, new data have shown that there are at least two generations of gabbroic bodies: (1) those associated with the greenstone belt, such as the Bemau and De Goeje complexes, which have been dated in French Guiana at around $2147 \mathrm{Ma}$ (Tampok gabbro, Pb-zircon evaporation; Delor et al., 2003a), and (2) a much younger suite in western and central Suriname, the Lucie Gabbro, dated at 1985 Ma (see below). De Roever \& Bosma (1975) suggested that the Bemau-type bodies should not be included in the De Goeje Gabbro, although this has not been heeded in their later papers. To avoid confusion we prefer to abolish the name De Goeje Gabbro altogether (De Roever, 2014) and introduce Bemau Ultramafitite for those in the greenstone belt and Lucie Gabbro for the younger suite.

The Bemau ultramafic complex in Saramacca consists of websterites, dunites, clinopyroxenites and their metamorphosed 


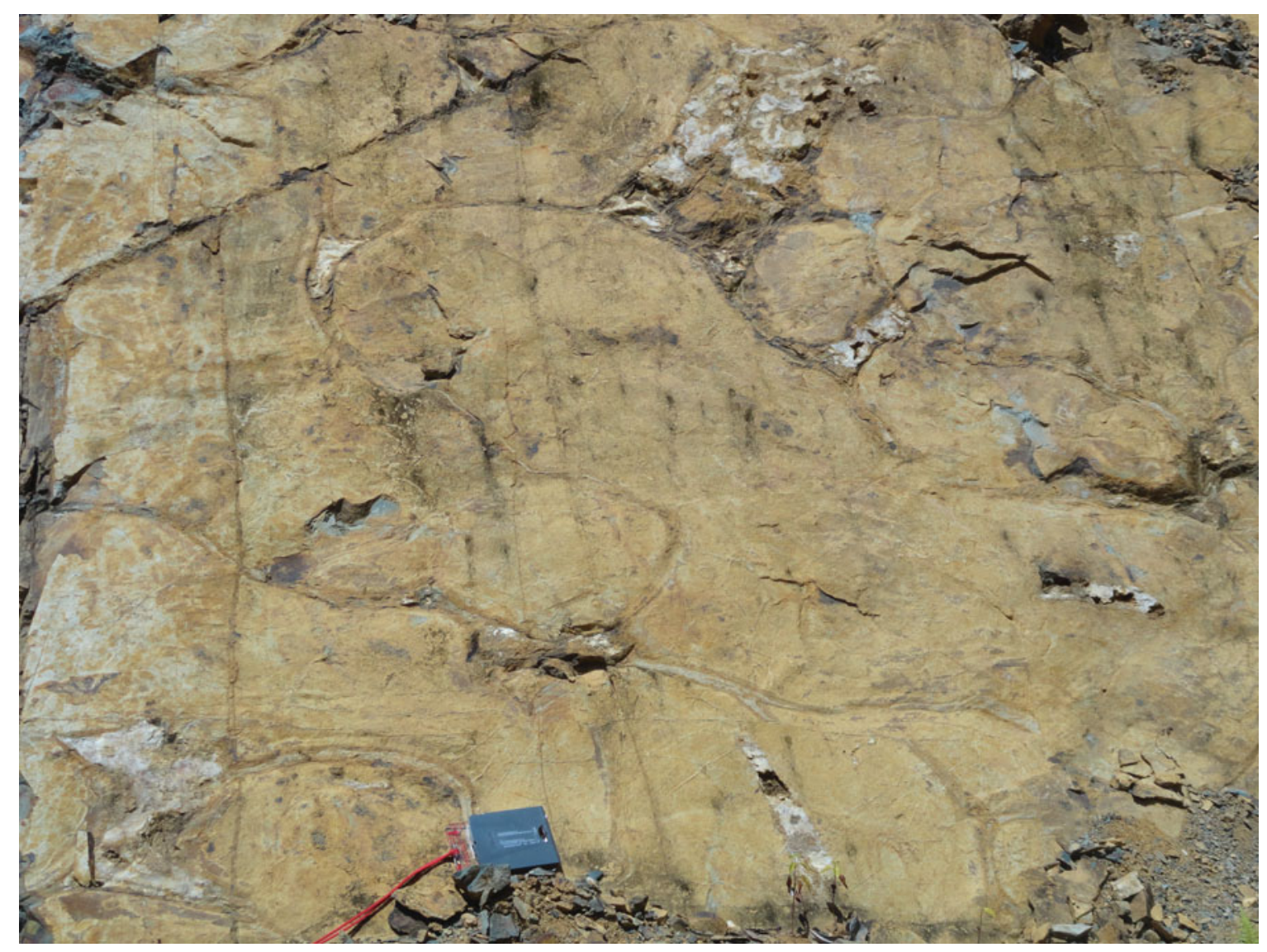

Fig. 5. Pillow structures in Paramaka metabasalts from Poederberg, Stonbroekoe Mountains.

equivalents, ultramafic schists with serpentine, chlorite, tremolite, talc and carbonate. They are associated with minor metagabbros and quartzdiorites. Both the ultramafics and the metagabbro and quartzdiorite show enrichment of LREE similar to modern andesites and high-alumina basalts (Veenstra, 1983). The De Goeje Gabbro in southeast Suriname shows similar REE patterns (Bosma et al., 1980). The geochemical data suggest that the Bemau ultramafics result from fractional crystallisation of gabbroic-andesitic parent magma by early separation of olivine, magnetite, clinopyroxene and minor orthopyroxene, and later intercumulus crystallisation of amphibole, phlogopite and plagioclase. The metagabbro and quartzdiorite represent the residual liquids after separation of the cumulates. It is conceivable that the Bemau Ultramafitite bodies represent the feeder pipes of the subduction-related andesites in the Paramaka Formation (Veenstra, 1983; De Roever, 2014).

\section{Kabel Tonalite}

Large parts of the central greenstone belt are occupied by ellipsoidal batholiths of tonalites, trondhjemites and granodiorites, designated as Kabel Tonalite by Bleys (1951), after Kabel village, now submerged in the Afobaka storage lake. The contacts with the surrounding Paramaka rocks are conformable in such a way that the metavolcanics, usually in the amphibolite facies, wrap around the outlines of the intrusions, as is clearly visible from the LANDSAT imagery (Kroonenberg \& Melitz, 1983). This configuration suggests diapiric ascent of the TTG magma and contemporaneous deformation of the surrounding metavolcanics (Veenstra, 1983), a classic feature in many other Archean and Paleoproterozoic greenstone belts in the world. The westernmost body, the Saramacca batholith, has been studied in great detail by Veenstra (1983).

Tonalites are concentrated along the contact zones, while trondhjemites and granodiorites occupy the central part of the batholith. A similar concentric pattern is reported from the Central Guiana Batholith in French Guiana (Delor et al., 2003a), consistent with the diapiric nature of the batholith. The TTG rocks often display a foliated aspect, especially near the contact zones. In the field the tonalite shows sharp intrusive contacts with the ultramafic Bemau rocks (Veenstra, 1983). Elsewhere there are transition zones with banded migmatitic gneisses and amphibolites.

Tonalites contain hornblende and biotite as mafic minerals, trondhjemites only biotite. Oligoclase is the dominant feldspar in most rocks. Textures are clearly magmatic. Their $\mathrm{K}_{2} \mathrm{O} / \mathrm{Na}_{2} \mathrm{O}$ ratios are 0.24 for tonalites and 0.38 for trondhjemites, and 
they plot as VAG (volcanic arc granite) in the $\mathrm{Rb} / \mathrm{Yb}+\mathrm{Ta}$ discriminant plot of Pearce et al. (1984) (De Vletter \& Kroonenberg, 1987). They show a calc-alkaline differentiation trend (Holtrop, 1969), and are chemically indistinguishable from diapiric tonalite bodies in Archean greenstone belts (Veenstra, 1983). The whole range of tonalite zircon- $\mathrm{Pb}$ evaporation ages in neighbouring French Guiana is around 2.18-2.16 Ga in the north and south of the country, with younger ages around 2.15$2.13 \mathrm{Ga}$ in central French Guiana. From the continuation of the southernmost Suriname tonalite batholith into French Guiana a zircon-Pb evaporation age of $2141 \pm 8 \mathrm{Ma}$ has been obtained (Delor et al., 2003a). In Amapá, granitoids associated with subduction furnished ages between 2.19 and $2.13 \mathrm{Ga}$ (Avelar et al., 2002; Rosa-Costa et al., 2006, 2009).

\section{Armina Formation}

The Armina formation as used by GMD (1977) and Bosma et al. (1983) has had a long and confusing history of past name changes, due to uncertainty about its depositional environment and its stratigraphic position with regard to the Paramaka and Rosebel Formations and the Kabel TTG batholiths (cf. Doeve, 1957; D'Audretsch, 1957; 0'Herne, 1969a). Recent studies in the Rosebel Gold Mines (Daoust et al., 2011) and along the Marowijne River, including the type locality Armina Falls (Naipal \& Kroonenberg, 2016), have clarified its origin and stratigraphic position to a great extent.

The Armina Formation consists of regularly alternating sequences of low-grade metagreywacke and phyllite, called flysch facies by Bosma \& Groeneweg (1973) and since then indeed recognised as metaturbidites (Bosma et al., 1983, 1984; Daoust et al., 2011; Naipal \& Kroonenberg, 2016; Watson, 2008, Fig. 6). The sequences along the Marowijne river show individual flow units of $10 \mathrm{~cm}$ to $5 \mathrm{~m}$ thickness, starting with a coarse-grained graded metagreywacke bed, and topped by a few centimetres of fine-grained metasiltstone or phyllites with parallel or convoluted lamination, cross-bedding and locally climbing ripples. Three different metaturbidite facies have been distinguished on the basis of field, petrographic and diagenetic features, showing northwards slightly increasing maturity. Metamorphic grade also increases northwards, ranging from chlorite-sericiterich assemblages to biotite- and garnet-bearing ones, though all within the greenschist facies. Conspicuous calcsilicate nodules in one of the three metaturbidite facies consist of garnet, actinolite, clinozoisite and plagioclase. Chemically the variability within the individual flow units is greater than between the different facies. Monomineralic clasts are mainly quartz and (igneous) plagioclase grains. Lithic clasts are Paramaka metavolcanics, chert and phyllites, but also tonalite or trondhjemite fragments, suggesting that the TTG batholiths were already exhumed when the turbidites were deposited (Naipal \& Kroonenberg, 2016). This is corroborated by the juvenile isotopic character of metagreywackes in French Guiana (positive $\varepsilon(\mathrm{Nd})_{\mathrm{t}}$ values), which might testify to the erosion of the TTG granitoids, although metapelites give negative values (Delor et al., 2003a).

The Armina Formation metaturbidites in the Rosebel Gold Mine have conspicuous conglomeratic intercalations, consisting mainly of well-rounded, tectonically flattened metavolcanic and metagabbroic clasts, with little evidence for tonalitic sources (Watson, 2008; Daoust et al., 2011; Naipal \& Kroonenberg, 2016). Chondrite-normalised REE profiles from the mine are LREE-enriched, showing values varying between $44 \times$ and $213 \times$ chondrite and $\mathrm{La}_{\mathrm{N}} / \mathrm{Yb}_{\mathrm{N}}$ values between 8.4 and 33.1, with an average value of 17.9 , comparable to the value of 16.1 for calc-alkaline metavolcanic rocks (Daoust et al., 2011). According to the latter authors detrital zircons in the Armina Formation would indicate a maximum age of $2127 \pm 7$ Ma for the deposition of the metaturbidite sequence, citing Milési et al. (1995). However, Milési et al. (1995) refers to this age as belonging to the Rosebel Formation.

\section{Taffra Schist}

The contact zone between the Armina Formation and the Patamacca Two-Mica Granite (see below) in northeast Suriname is about $5 \mathrm{~km}$ wide, and is characterised by well-foliated coarsegrained staurolite-garnet-biotite schists, dubbed Taffra Schists in the past (Schols \& Cohen, 1951, 1953). Locally they contain kyanite, andalusite or fibrolite. While these rocks are generally considered to be contactmetamorphic equivalents of the Armina Formation, we prefer to consider them as a separate unit, as the characteristic turbiditic sedimentary structures of the Armina Formation are no longer discernible in them, and in some areas they border Paramaka-type rocks. Moreover, the pronounced schistosity and the mineral assemblages suggest regional rather than contact metamorphism of the pelitic protoliths. No modern data are available.

\section{Patamacca Two-Mica Granite}

At least five individual plutons of two-mica granite, called Patamacca Granite by Yang (2014), intrude into the Armina Formation in northeast Suriname, causing aureoles of staurolitegarnet-biotite schists. The granites are slightly gneissose, and near the margins of the granites many lens-shaped metasedimentary enclaves are found, with a strike similar to that of the adjoining metasediments (Bosma et al., 1984). These features, together with the schistosity and medium-pressure mineral assemblages in the adjoining Taffra Schist, suggest that the ascent of these plutons may also have been diapiric, just like the Kabel Tonalite. The contact zone between the Taffra Schist and the granite contains numerous pegmatite veins, some of which carry amblygonite, cassiterite, tantalite and beryl (Montagne, 1964). Based on major element composition the Patamacca Granite can be classified as a peraluminous S-type 


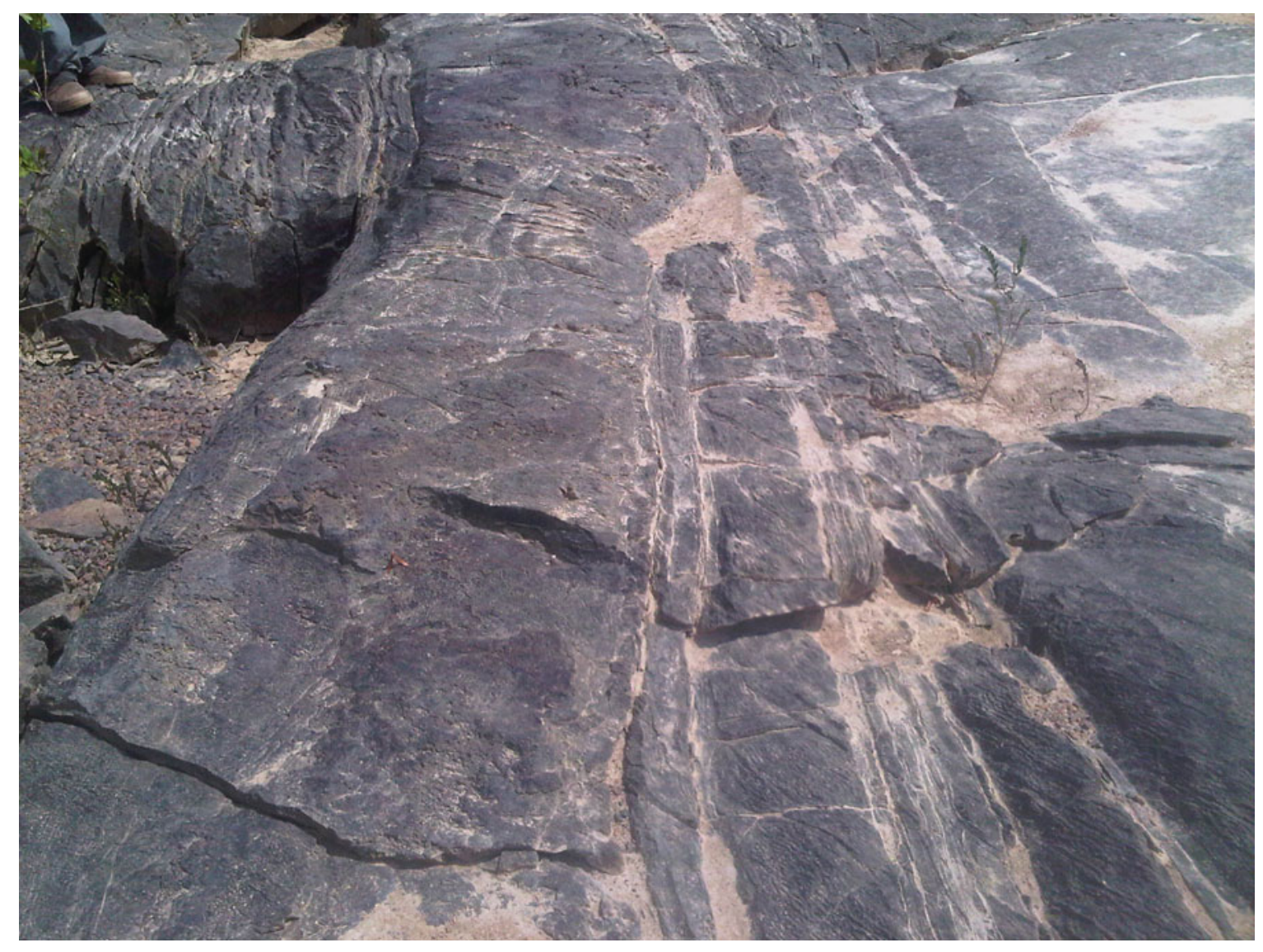

Fig. 6. Armina Formation metaturbidite sequence at the type locality, Marowijne River.

granite, pointing to derivation from a high-grade metapelitic parent lithology. Combined major and trace element signatures suggest an origin in a syn-collisional tectonic setting (Yang, 2014). The small leucocratic garnet-bearing two-mica granite in the Rosebel Gold Mine area (Brinck, 1955) is peraluminous, has a highly enriched REE distribution and has the most calcalkaline affinity of all the rocks at the mine (Watson, 2008). In French Guiana a U-Pb (SIMS) age of $2060 \pm 4$ Ma was obtained on zircon from the Petit Saut two-mica granite from the same belt, and monazite from the same granite gave a U-Th- $\mathrm{Pb}$ (EPMA) age of $2059 \pm 23$ Ma (Delor et al., 2003a).

\section{Rosebel Formation}

The uppermost metasedimentary formation in the Marowijne Greenstone Belt is the Rosebel Formation, named by Schols \& Cohen (1951) for the Rosebel Savanna area, the site of the present-day open-pit Rosebel Gold Mine. The Rosebel Formation overlies the Armina and Paramaka Formations unconformably with a basal metaconglomerate, as has been observed in the mine (Watson, 2008; Daoust et al., 2011). Higher in the sequence conglomeratic intervals also occur. The most characteristic component is a cross-bedded greyish quartz-rich metaarenite, with magnetite grains concentrated at the base of the foresets (Fig. 7). The metaconglomerates are polymictic, quartzrich, but with also abundant phyllite clasts (Fig. 8) supposedly derived from the underlying Armina Formation (Bosma et al., 1984).

In Landsat imagery the Rosebel and Armina Formations show strikingly different morphologies (Cohen \& Van der Eijk, 1953; 0'Herne, 1969b; Kroonenberg \& Melitz, 1983). Soils on Rosebel Formation are whitish and sandy, while those in the Armina Formation are reddish and clayey. Nevertheless distinction between the two formations is sometimes difficult in the field, especially when less mature sediments are intercalated (cf. Daoust et al., 2011). Naipal \& Kroonenberg (2016), using factor analysis on major element analytical data, show that real Rosebel rocks are consistently lower in Fe and Na than Armina sediments, and that many samples from the mine may have been misclassified by Daoust et al. (2011) as Rosebel.

Sedimentary structures in the Rosebel metasandstones suggest deposition in a fluvial environment. The higher maturity of the sediments suggests provenance from a more weathered hinterland; the magnetite may be all that remains from deep chemical weathering of the Paramaka metavolcanics. This means that an interval of uplift, erosion and deep weathering must have occurred between the deposition of the Armina turbidites and the Rosebel fluvial sands. The equivalent in French Guiana, the 


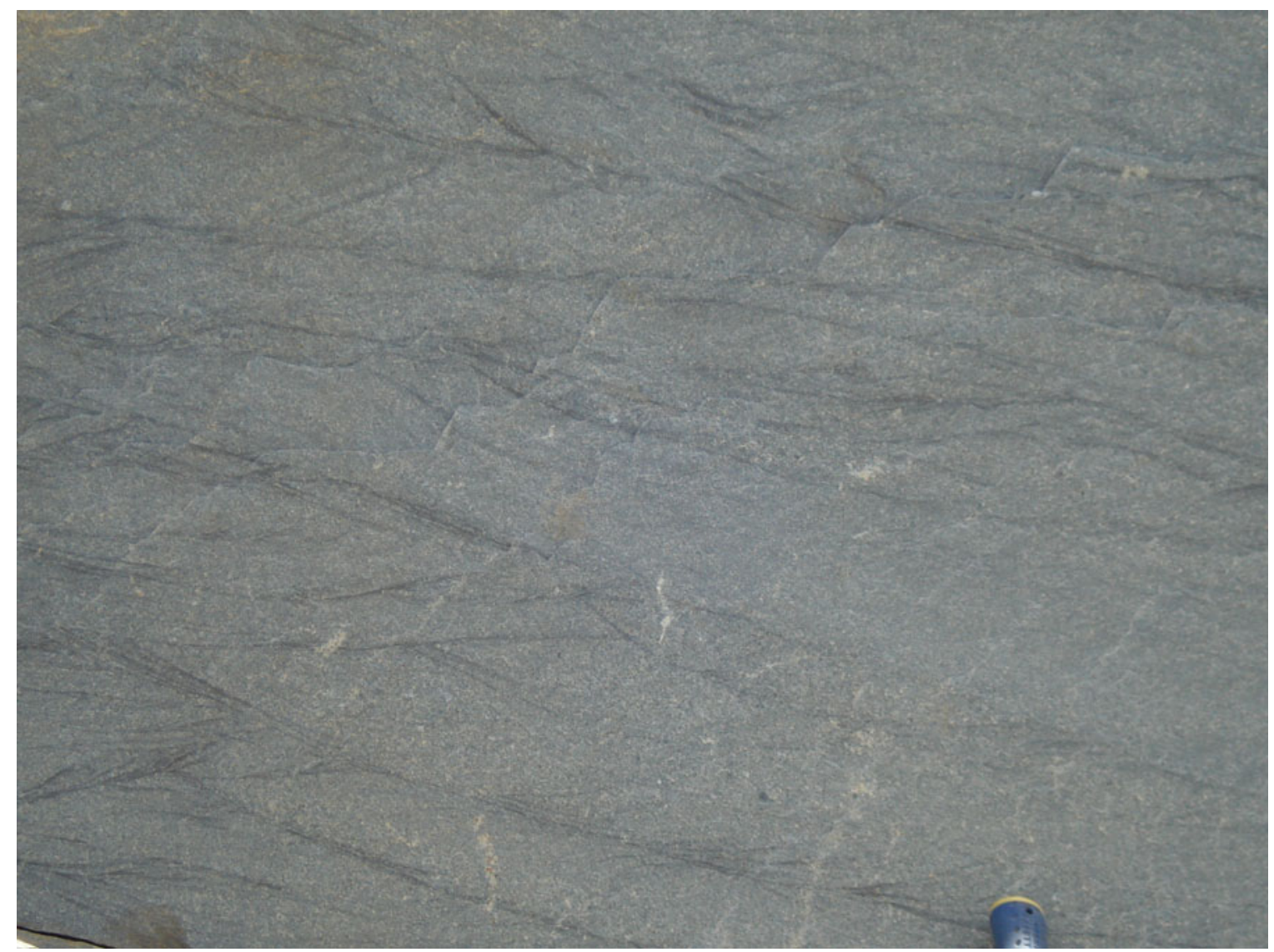

Fig. 7. Cross-bedded Rosebel meta-arenite, with magnetite concentrated at the base of the foresets. Royal Hill pit, Rosebel Gold Mine.

Upper Detrital Unit, is supposed to have been deposited in pullapart basins formed in a late stage of transpressional deformation of the greenstone belt (Milési et al., 1995; Vanderhaeghe et al., 1998; Delor et al., 2003a). The U-Pb geochronology of detrital zircons on these rocks in French Guiana suggests a maximum age of deposition of $2115 \pm 4$ Ma (Milési et al., 1995; Daoust et al., 2011), and possible derivation from the Kabel Tonalite.

In western Suriname, west of the Bakhuis horst, the sericite quartzites and oligomictic quartz-rich metaconglomerates of the Ston Formation crop out next to the Paramaka-like Matapi 'spilites' (Loemban Tobing, 1969; see above). They are more mature than the Rosebel Formation because of the total absence of feldspar, and show a higher degree of quartz recrystallisation, obliterating the clastic fabric of the rock. Metaconglomerates also include, next to quartz pebbles, metachert-like fragments probably derived from Paramaka-like chemical metasediments. In contrast to the eastern limb of the greenstone belt they show open folding, and have been observed by Loemban Tobing (1969) to be intruded by sills of the overlying Dalbana metavolcanics (see below), although later unpublished reports suggest the Ston to be conformably overlain by Dalbana metavolcanics (see below). Locally the quartzites show contact metamorphism by the intrusion of surrounding Wonotobo Granites (see below).
Gibbs \& Barron (1993) correlate the Ston Formation with the Muruwa Formation in Guyana. No modern geochronological data are available.

\section{Sara's Lust Gneiss}

Along both its northern and its southwestern flank the greenstone belt is bordered by a zone of high-grade metamorphic, often migmatitic gneisses and amphibolites (Bosma et al., 1983, 1984). Outside the greenstone belt many mappable enclaves of similar rocks occur, in the vast expanses occupied by the Older Granites in central Suriname (see below). We call these rocks Sara's Lust Gneiss, after the crushed rock quarry at the old plantation with that name along the Suriname River (Fig. 9). On the 1977 map these rocks received the same signature as the highgrade rocks in the Coeroeni area, but recent data show that they are probably over $100 \mathrm{Ma}$ older, and therefore preferably go with their own name.

The rocks in the northern segment of the belt are predominantly migmatitic hornblende-biotite gneisses, biotiteplagioclase gneisses, garnet-biotite gneisses and quartzofeldspathic gneisses, with minor amphibolites, locally with garnet or clinopyroxene, and furthermore pelitic sillimanite-biotitemuscovite gneisses and calcsilicate rocks, clearly of supracrustal 


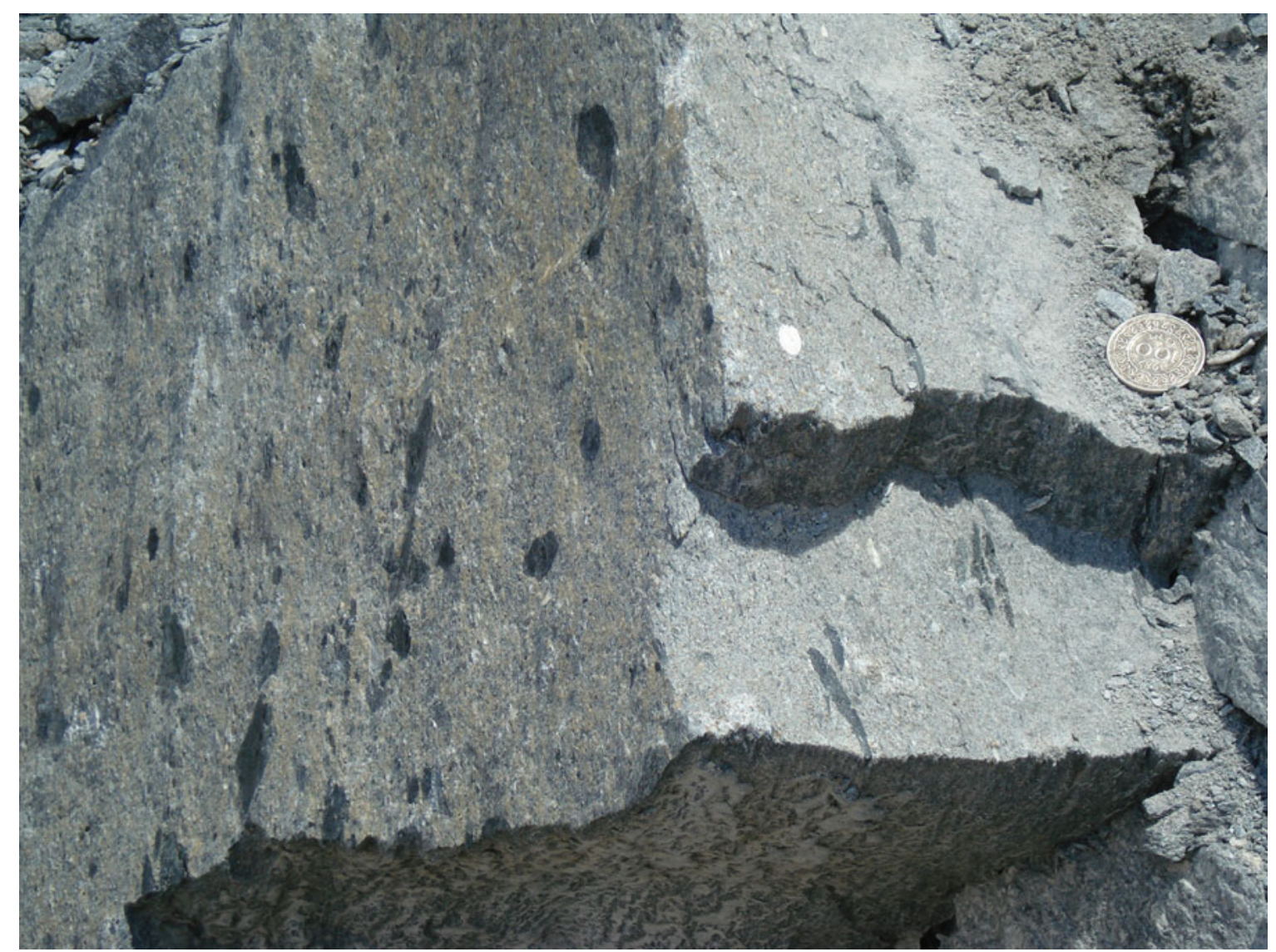

Fig. 8. Rosebel Formation meta-arenite with phyllite and quartz pebbles (left: parallel to bedding, right: perpendicular to bedding). Royal Hill pit, Rosebel Gold Mine.

origin (Fig. 9). In the southwestern segment of the belt near the De Goeje Mountains andalusite-cordierite sillimanite schists, garnet-biotite gneiss and pyroxene gneisses are also found (Van Eijk, 1961). Metamorphism is mainly in the higher amphibolite facies, but some gneisses and amphibolites in the southern belt and in the enclaves contain orthopyroxene, testifying that granulite facies conditions were reached (Barink, 1975; Ho Len Fat, 1975). The gneisses in the northern belt are not simply the higher-grade equivalents of the adjacent Taffra Schists because the latter are mainly pelitic, whereas the Sara's Lust Gneiss is mostly tonalitic in composition. They might, however, be the high-grade metamorphic equivalents of the Paramaka metaandesites and related rocks.

In the continuation of the southern gneiss belt into southern French Guiana tonalitic gneisses of the Tamouri Complex, associated with gneisses with varying amounts of biotite, garnet and sillimanite, are dated between 2155 and $2165 \mathrm{Ma}$ (Delor et al, 2003a). No age data are available from the northern belt. In the Île de Cayenne, French Guiana, ages of over $2200 \mathrm{Ma}$ have been found for trondhjemite gneiss, amphibolite and gabbro (Vanderhaeghe et al., 1998; Delor et al., 2003a). These are the oldest rocks found in the greenstone belt so far, but it is uncertain whether Sara's Lust Gneiss can be correlated with them as Delor et al. (2003a) suggest.

\section{Older granites}

Almost the whole southeastern part of Suriname outside the greenstone belt is occupied by vast expanses of greyish, inhomogeneous, often slightly gneissic and migmatitic granites of varying grain size, composition and colour index (Fig. 3, Table 1). This area was indicated by IJzerman (1931) as Gran Rio Massif. Within the Older granites irregular outcrops of deep-level pyroxene granites have been mapped, designated Pikien Rio Granite, often associated with enclaves of granulitefacies gneisses (Fig. 3). Furthermore there are mappable enclaves of obviously Paramaka-derived gondites (manganiferous spessartine quartzites, Lada Soela; Bosma, 1969), itabirites (iron quartzites) and other metacherts (Tapajé; Bosma, 1973a), chromite occurrences (Den Hengst, 1975) and copper-bearing cordierite diorites (Weko Soela; Groeneweg, 1971; Kroonenberg, 1977). This suggests that the Older granites constitute a deepseated but incompletely homogenised magmatic unit formed by melting of the TTG-greenstone belt (Delor et al., 2003b). New zircon $\mathrm{U}-\mathrm{Pb}$ ages obtained from them of around $2.1 \mathrm{Ga}$ also corroborate this view.

The border with the Younger granites in the southwest runs in a north-south direction, approximately along the Eilerts de Haan Mountains, the divide between the Marowijne and 


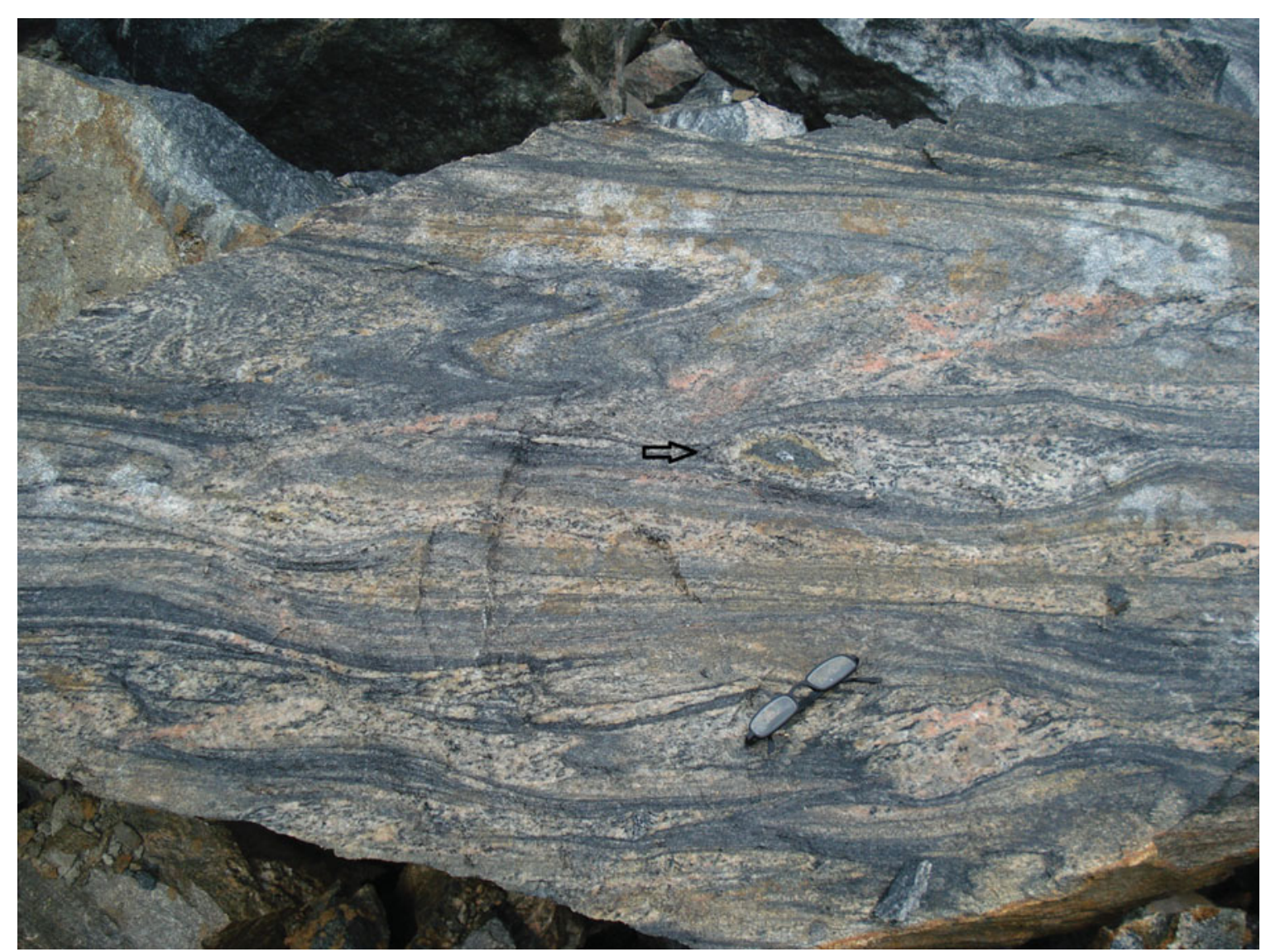

Fig. 9. Intensely folded migmatitic Sara's Lust Gneiss at type locality. Black arrow indicates calcsilicate nodule with carbonate core.

Corantijn drainage basins in southern Suriname (De Roever, 2014). In earlier papers (Bosma et al., 1983, 1984) the inhomogeneous eastern and homogeneous western granites were thought to represent products of coeval magmatism, only exposed at different crustal level. New data show that their ages are more than $100 \mathrm{Ma}$ apart and that they represent entirely different phases of Trans-Amazonian magmatism.

\section{Gran Rio Granite}

The most common granites among the Older granites are medium- to coarse-grained biotite granite and hornblendebiotite granite, in part with alkali feldspar megacrysts. They may show vague banding and migmatitic ghost structures. This rock unit was named Gran Rio Granite by IJzerman (1931). It crops out extensively along the Gran Rio River and the Tapanahony River and its tributaries (Haug, 1966; Groeneweg, 1969; Barink, 1975; Ho Len Fat, 1975). Chemical data are not available. Recently four samples from this unit in southeastern Suriname have been dated by Lafon (2013) using the ${ }^{207} \mathrm{~Pb}-$ ${ }^{206} \mathrm{~Pb}$ evaporation method for zircons (see Table 2 ). The age data are slightly younger than the youngest rocks of the the greenstone belt, and therefore we consider these granites as representing the deeper anatectic products of the greenstone belt.

\section{Pikien Rio Pyroxene Granite}

Within the area of the Older granites, as along the Pikien Rio (Ho Len Fat, 1975) irregular-shaped outcrops of pyroxene granites occur, often in association with enclaves of migmatitic, in part granulite-facies gneisses. Clinopyroxene is the most common mafic mineral, but locally orthopyroxene is also present. The latter rocks may be called charnockites. Charnockites and pyroxene granites are also widespread in the Bakhuis Mountains in West Suriname (Kabalebo Charnockite), and on the 1977 map they were indicated with the same legend unit as those described here. However, a recent ${ }^{207} \mathrm{~Pb}-{ }^{206} \mathrm{~Pb}$ age obtained by Lafon (2013) shows that the Pikien Rio pyroxene granites are just as old as the Gran Rio granites and more than 100 Ma older than the Kabalebo Charnockite (cf. Klaver et al., 2015, 2016; see also below). There is a striking concentration of younger gabbroic intrusions in the pyroxene granites.

\section{Bakhuis Granulite Belt}

The Bakhuis Granulite Belt (BGB; De Roever et al., 2003a; Klaver et al., 2015) is a NE-SW striking, $100 \mathrm{~km}$ long, $40 \mathrm{~km}$ wide geotectonic unit in the Bakhuis Mountains, northwest Suriname, situated in a prominent horst structure, the Bakhuis horst, 
Table 2. Geochronology of Older granites from central Suriname (for sample location see Fig. 4).

\begin{tabular}{lllll}
\hline Number on Fig. 4 & Sample number & Method & Age (Ma) & Rock type \\
\hline 1 & SU65/2192-ED-R-65 & $\mathrm{Pb}-\mathrm{Pb}$ & $2098 \pm 3$ & Biotite granite \\
2 & CP806/2192-ED-R-806 & $\mathrm{Pb}-\mathrm{Pb}$ & $2090 \pm 2$ & Biotite granite \\
3 & HK1665/2192-ED-R-665 & $\mathrm{Pb}-\mathrm{Pb}$ & $2102 \pm 2$ & Biotite granite \\
4 & HK1697/2192-ED-R-697 & $\mathrm{Pb}-\mathrm{Pb}$ & $2085 \pm 5$ & Biotite granite \\
5 & SU66/2192-ED-R-66 & Pb-Pb & $2097 \pm 1$ & Pafon (2013) \\
\hline
\end{tabular}

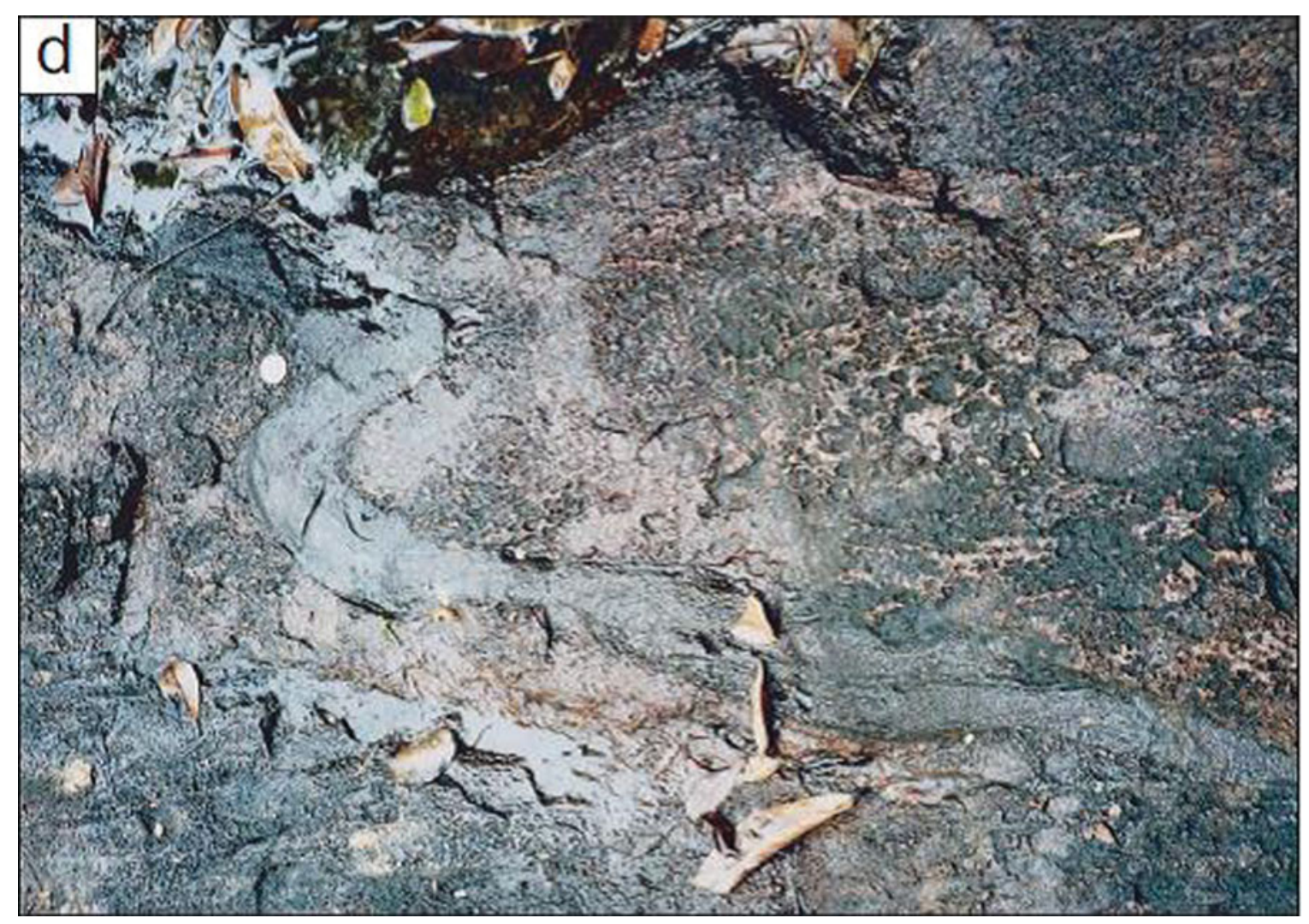

Fig. 10. Synkinematic metadolerite dyke in banded granulite, from De Roever et al., $2003 a$.

uplifted in the Mesozoic along pre-existing Mesoproterozoic mylonite zones and Paleoproterozoic lineaments (Fig. 3, Table 1). The horst structure continues below the sedimentary succession of the coastal area, as can be seen in seismic imagery both onshore and offshore. Faulting and uplift are still active and lead to offsets in the Mesozoic and Cenozoic sedimentary sequences (Bosma \& De Roever, 1975; Wong, 2014). The BGB shows a domal structure at its northeast end, as indicated by banding and foliation, which is cut off by the southeast horst fault (De Roever, 1975). The domal structure is also seen at the southwest end (Dahlberg, 1975), where the belt disappears below mylonitic granites. In the Tijgerval area, near the Corantijn River, more than $50 \mathrm{~km}$ to the WSW, granulite-facies gneisses are found with a considerable similarity to Bakhuis belt gneisses (Dahlberg, 1975; Kroonenberg, 1975). The Tijgerval gneisses may be connected to the Kanuku Granulite Belt of southern Guyana as part of the Central Guiana Granulite Belt (Kroonen- berg, 1976), or may represent an isolated occurrence. The wide zone in between has been poorly explored (see discussion below under Coeroeni Gneiss Belt).

The Bakhuis Granulite Belt consists mainly of banded intermediate and mafic granulites, the Bakhuis Granulite, with subordinate (mappable) metapelitic gneisses, the Stondansi Gneiss. The BGB is an ultrahigh temperature (UHT) metamorphic domain, with peak conditions at $950-1050^{\circ} \mathrm{C}$ and $81 / 2-9 \mathrm{~Kb}$ (De Roever et al., 2003a; Klaver et al., 2015).

The common presence of orthopyroxene in melanosomes and leucosomes indicates that both metamorphism and anatexis took place under granulite facies (UHT) conditions. The granulites and gneisses show mainly isoclinal or tight folding, with steeply dipping fold axes (De Roever et al., 2003a). Banding and foliation are generally subvertical. Narrow $(<1 \mathrm{~m})$ high-grade metamorphic metadolerite dykes transect the granulites (Fig. 10). Some dykes show folding or boudinage, 
which suggests synkinematic intrusion, others are straight and postkinematic.

In the past the Bakhuis rocks were suspected to be of Archean age because of their granulite-facies metadolerite dykes (De Roever, 1975), scattered Rb-Sr isochron ages suggesting a minimum age of $2.4 \mathrm{Ga}$ (Priem et al., 1978) and similarity with the Imataca granulites in Venezuela (Gaudette et al., 1978; see also Bosma et al., 1983, 1984). However, Lafon (2013) determined $\mathrm{Nd} \mathrm{T}_{\mathrm{DM}}$ model ages of 2.2-2.4 Ga, precluding an Archean age and indicating Paleoproterozoic protoliths (De Roever et al., 2003a). The UHT metamorphism occurred around 2.07-2.05 $\mathrm{Ga}$ (Table 3), as determined by zircon $\mathrm{Pb}-\mathrm{Pb}$ and $\mathrm{U}-\mathrm{Pb}$ dating (De Roever et al., 2003a; Klaver et al., 2015). The extreme heat required for UHT metamorphism was considered by Delor et al. (2003b) to have been generated by mantle upwelling in a zone of Late Trans-Amazonian crustal stretching due to prolonged sinistral shearing during oblique plate convergence. Evidence for substantial coeval mafic magmatism has, so far, not been found. The belt was intruded by younger charnockite, anorthosite, metagabbro and gabbro plutons around 1.99-1.98 Ga (De Roever et al., 2003a; Klaver et al., 2015, 2016).

\section{Bakhuis Granulite}

The granulites are mainly intermediate or mafic in composition and show marked banding on the centimetre to decimetre scale. The dominant compositional banding is inherited from the supracrustal protolith, whereas finer parallel banding is caused by incipient migmatisation. The protolith was in part sedimentary, as indicated by the presence of partly mappable intercalations of pelitic gneisses, sillimanite quartzites, spessartine quartzites and calc-silicate granulites. Part of the mafic granulites probably are of volcanic origin, as they plot in the island arc tholeiite field in trace element discrimination diagrams (Klaver et al., 2015). Intermediate granulites predominate. They are dark-grey, banded rocks, with granoblastic plagioclase and quartz besides orthopyroxene, with clinopyroxene and hornblende in darker bands, and with only orthopyroxene in coarse-grained leucosome bands. The plagioclase typically is antiperthitic. Perthitic alkali-feldspar and mesoperthite occur mainly in rather rare felsic granulites. Mafic granulites comprise both hornblende-rich pyroxene amphibolites and nearly hornblende-free (pyroxene-rich) granulites, commonly with some biotite and more rarely with garnet.

\section{Stondansi Gneiss}

The metapelitic gneisses, commonly rich in sillimanite and migmatitic, are called after the large occurrence near the Stondansi Falls in the Nickerie River. In a rather large metapelite area in the northeast of the BGB mineral assemblages orthopyroxene + sillimanite + quartz and sapphirine + quartz have been found, characteristic for UHT metamorphism (De Roever et al., 2003a; Klaver et al., 2015). Elsewhere the metapelitic gneisses mainly show an assemblage cordierite + sillimanite, also formed at UHT conditions. Orthopyroxene crystals show a marked zonation, with up to $10 \% \mathrm{Al}_{2} \mathrm{O}_{3}$ in the core, and considerably lower $\mathrm{Al}_{2} \mathrm{O}_{3}$ along the rim. This indicates an anticlockwise cooling path after peak UHT metamorphism (De Roever et al., 2003a). Cordierite in the gneisses is commonly partially or fully replaced by fine-grained sillimanite, Al-poor orthopyroxene and biotite, with additional kyanite or, more rarely, andalusite. This points to an anticlockwise cooling path. In these cordierite pseudomorphs a new beryllium-bearing $\mathrm{Mg}-\mathrm{Al}$ silicate, surinamite, was discovered by De Roever et al. (1976).

\section{Coeroeni Gneiss Belt}

In southwestern Suriname another southeast trending highgrade belt occurs, called the Coeroeni Gneiss Belt (Fig. 3, Table 1). It consists of amphibolite-facies quartzofeldspathic gneisses and amphibolite-facies and granulite-facies metapelitic gneisses with assemblages including sillimanite, cordierite and garnet, as well as minor amphibolites, quartzites, calcsilicate rocks, marbles and ultramafic rocks (Kroonenberg, 1976). In Landsat imagery and aerial photographs quartzofeldspathic and pelitic gneisses are morphologically clearly distinct from each other (Kroonenberg \& Melitz, 1983). The Coeroeni Gneiss Belt forms a domal structure with the granulite-facies rocks in the core and the amphibolite-facies rocks around it. Isoclinal folding with vertical fold axes is the rule, and NW-SE strikes predominate (Fig. 11). Discordant pegmatite veins are common.

There are different opinions as to the relation between the Coeroeni Gneiss Belt, the Bakhuis Granulite Belt and the Kanuku Belt in Guyana. Kroonenberg (1976) considered them as a single Central Guiana Granulite belt with three branches, as a kind of triple junction, that continues into Brazil. Gibbs and Barron (1993) show a connection on their map between Bakhuis and Kanuku but not with Coeroeni, whereas Delor et al. (2003b) connect Coeroeni and Kanuku but give Bakhuis a separate status. Recently, Fraga et al. (2008, 2009a,b) defined a CauaraneCoeroeni Belt running from the Roraima Province in Brazil through Kanuku into Coeroeni, but again without including Bakhuis.

Arguments for either solution are related to age, metamorphic history, structural features and magnetic character. A separate status for the Bakhuis Granulite Belt was advocated in the past on the base of the supposed Archean age and the presence of deformed metadolerite dykes, which have not been found in Coeroeni (Bosma et al., 1983, 1984; De Roever et al., 2003a). An Rb-Sr isochron by Priem et al. (1977) of $2042 \pm 97$ Ma with an initial isotope ratio of 0.7027 precluded any Archean history for the Coeroeni rocks. However, as discussed above, since then no ages older than 2.07-2.05 Ga have been obtained for the 
Table 3. Geochronological data Bakhuis Granulite Belt (for location samples see Fig. 4).

\begin{tabular}{|c|c|c|c|c|c|}
\hline Number on Fig. 4 & Sample number & Method & Age (Ma) & Rock & Reference \\
\hline 6 & Sur408 & $\mathrm{U}-\mathrm{Pb}$ (conv) & $2026 \pm 20$ & Intermediate granulite & Priem et al. (1978) \\
\hline 7 & SU11f & $\mathrm{Pb}-\mathrm{Pb}$ & $2072 \pm 4$ & Garnet-sillimanite gneiss & De Roever et al. (2003a) \\
\hline 8 & SU3f & $\mathrm{Pb}-\mathrm{Pb}$ & $2086-2153$ & Intermediate opx gneiss & De Roever et al. (2003a) \\
\hline 9 & LC57-2a & $\mathrm{Pb}-\mathrm{Pb}$ & $2055 \pm 3$ & Garnet-bearing gneiss & De Roever et al. (2003a) \\
\hline 10 & LC57-2b & $\mathrm{Pb}-\mathrm{Pb}$ & $2081 \pm 2$ & Pegmatite & De Roever et al. (2003a) \\
\hline 11 & SU12aDF & $\mathrm{Pb}-\mathrm{Pb}$ & $2056 \pm 4$ & Metadolerite dyke & De Roever et al. (2003a) \\
\hline 12 & SU12aDV & $\mathrm{Pb}-\mathrm{Pb}$ & $2060 \pm 4$ & Metadolerite dyke & De Roever et al. (2003a) \\
\hline 13 & SU15 & $\mathrm{Pb}-\mathrm{Pb}$ & $2065 \pm 3$ & Pegmatite & De Roever et al. (2003a) \\
\hline 14 & SU6b & $\mathrm{Pb}-\mathrm{Pb}$ & $2065 \pm 2$ & Mylonitic charnockite & De Roever et al. (2003a) \\
\hline 15 & SU11d & Monazite U-Th-Pb & $2127 \pm 15$ & Garnet-sillimanite gneiss & De Roever et al. (2003a) \\
\hline 16 & SU10e2 & Monazite U-Th-Pb & $2007 \pm 11$ & Leucogranite & De Roever et al. (2003a) \\
\hline 17 & MKS40a & U-Pb LA-ICP-MS & $2072.6 \pm 7.3$ & Sillimanite gneiss & Klaver et al. (2015) \\
\hline 18 & KG515 & SHRIMP & $2026 \pm 39$ & Sillimanite cordierite gneiss & Cordani \& Fraga (unpublished) \\
\hline
\end{tabular}

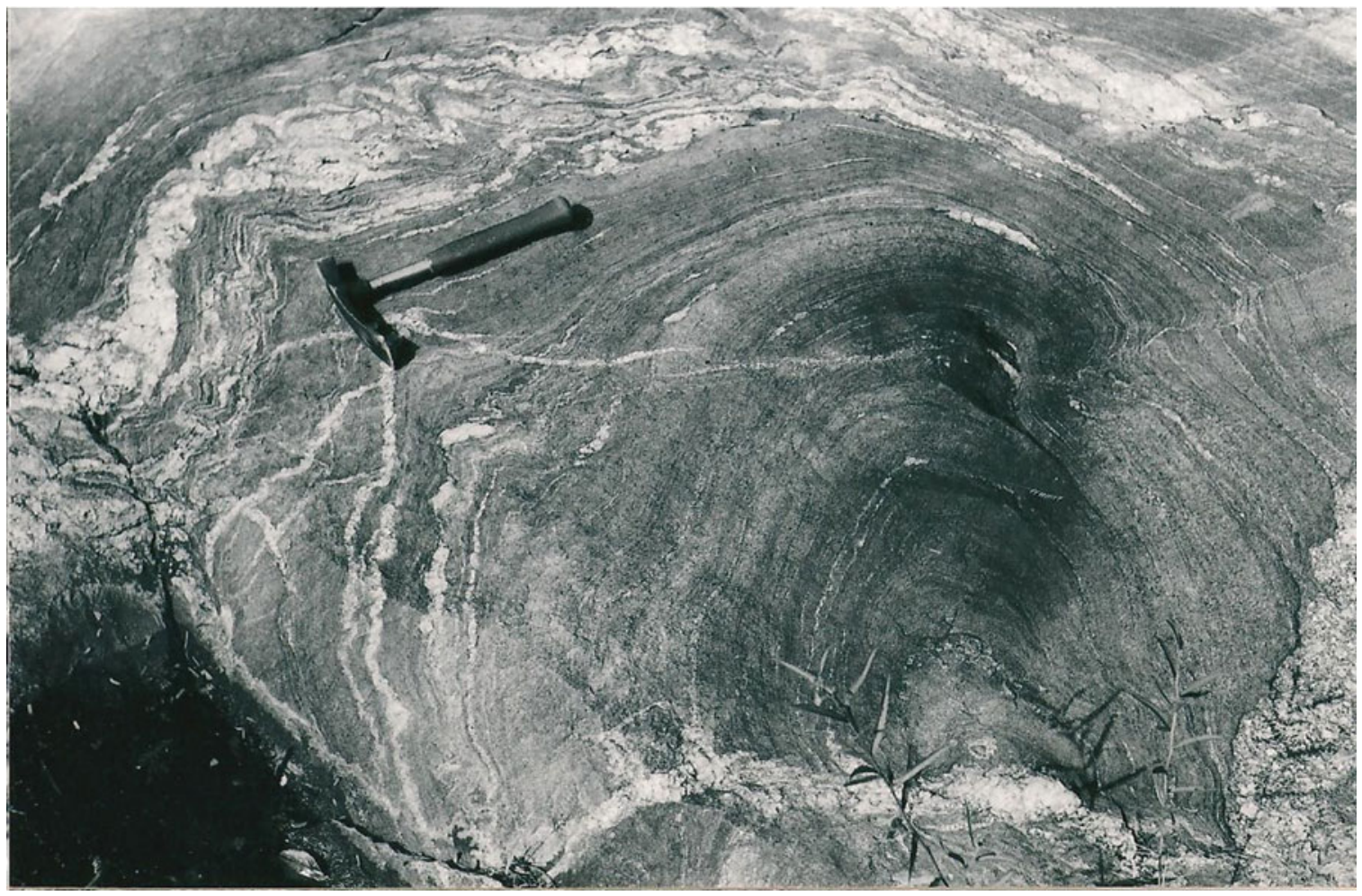

Fig. 11. Isoclinally folded migmatitic biotite-muscovite gneiss, Coeroeni River.

Bakhuis Granulite Belt either, and Nd model ages around 2.3 Ga suggest a juvenile character (De Roever et al., 2003a; Klaver et al., 2015). In the Coeroeni Gneiss Belt, new, so far largely unpublished $\mathrm{U}-\mathrm{Pb}$ zircon data show two groups of ages: one between 2.08 and $2.05 \mathrm{Ga}$ and another between 1.99 and 1.97 Ga (Table 4, Fig. 12; see below). In the Kanuku Belt one single $2.04 \mathrm{Ga} \mathrm{U}-\mathrm{Pb}$ zircon age has been found for a garnet-sillimanite gneiss, with all other ages between 1.99 and $1.96 \mathrm{Ga}$ (Nadeau et al., 2013). Also the two-phase anticlockwise metamorphic history of the three belts is similar (see below), although only in the Bakhuis Granulite Belt up to UHT conditions. These data add weight to a common origin of the three belts, as will be discussed at the end of this paper.

\section{Werekitto Gneiss}

Quartzofeldspathic gneisses cover a large area in the Coeroeni Gneiss belt, and are here designated as Werekitto Gneiss. Robert Schomburgk (1845) mentions that the Pianoghotto indians living at the headwaters of the Koetari River called the decomposed gneiss they used for grinding 'Were Kitto', and in the Werekitto Falls in the Corantijn River these rocks are 
Table 4. U-Pb geochronology of Coeroeni Gneiss Belt rocks (for location samples see Fig. 4).

\begin{tabular}{llllll}
\hline Number on Fig. 4 & Sample number & Method & Age (Ma) & Rock & Reference \\
\hline 19 & VLK1 zircon & $\mathrm{Pb}-\mathrm{Pb}$ & $1967 \pm 5$ & Tonalite gneiss & De Roever et al. (2010, 2015) \\
20 & VLK1 titanite & $\mathrm{U}-\mathrm{Pb}$ & $1961 \pm 17$ & Tonalite gneiss & De Roever et al. (2010, 2015) \\
21 & SU28B & $\mathrm{Pb}-\mathrm{Pb}$ & $1991 \pm 25$ & Biotite gneiss & De Roever et al. (2010, 2015) \\
22 & SU23a & Pb-Pb & $2060-2890$ & Cordierite tonalite & De Roever et al. (2010, 2015) \\
23 & KG811 & SHRIMP & $2079 \pm 19$ & Garnet-sillimanite-cordierite gneiss & Cordani \& Fraga (unpublished) \\
24 & KG826 & SHRIMP & $2050.8 \pm 5.0$ & Cordierite gneiss, first peak Fig. 12 & Cordani \& Fraga (unpublished) \\
25 & KG826 & SHRIMP & $1986 \pm 15$ & Same, second peak Fig. 12. & Cordani \& Fraga (unpublished) \\
26 & SB24 & SHRIMP & $1983.9 \pm 5.4$ & Quartzofeldspathic gneiss & Cordani \& Fraga (unpublished) \\
27 & SB31 & SHRIMP & $1993.9 \pm 3.7$ & Leucogneiss & Cordani \& Fraga (unpublished) \\
28 & SB13 & SHRIMP & $1973.6 \pm 3.8$ & Quartzofeldspathic gneiss & Cordani \& Fraga (unpublished) \\
\hline
\end{tabular}

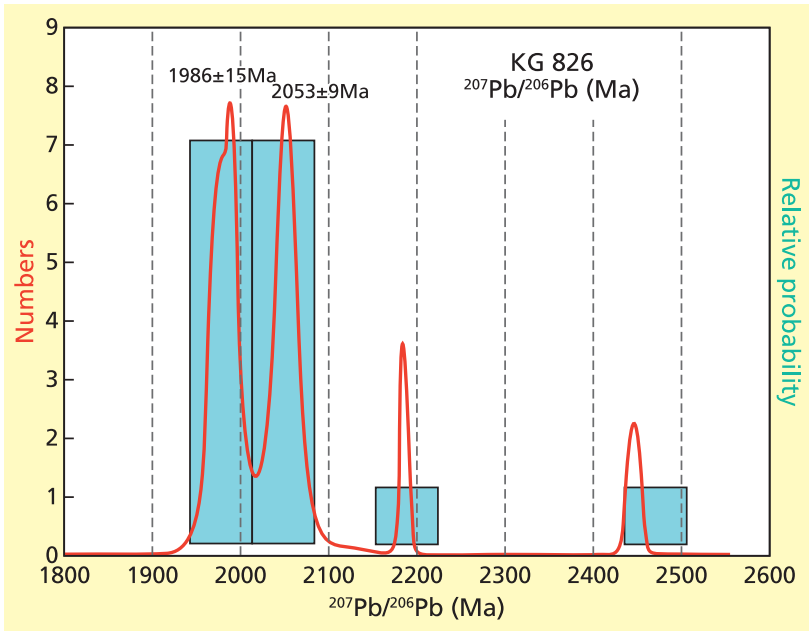

Fig. 12. U-Pb SHRIMP ages of zircon cores (2053 Ma) and rims (1986 Ma) of sample KG 826, cordierite-muscovite-biotite gneiss, in which cordierite is partly replaced by ferrogedrite, andalusite, sillimanite, staurolite and garnet. Lucie River, sample number 24, 25 in Fig. 4 and Table 4.

exposed. This unit encompasses a great variety of hornblendebiotite gneisses and biotite gneisses of tonalitic, trondhjemitic to granitic composition, which usually show some compositional banding, suggesting a largely supracrustal origin. They show commonly signs of incipient migmatisation and there are also some cross-cutting veins with alkalifeldspar megacrysts. Some biotite-plagioclase gneisses may represent semi-pelitic protoliths. Metamorphism is in the amphibolite facies (Kroonenberg, 1976).

\section{Amotopo Gneiss}

The second most common rock types in the Coeroeni Gneiss Belt, as seen in the Corantijn river near the newly established Trio village of Amotopo, are low-pressure amphibolite-facies pelitic gneisses, characterised by sillimanite, biotite and muscovite, often with either cordierite or garnet. Cordierite is often concentrated in centimetre-sized cordierite-quartz clots.
These gneisses are strongly migmatitic as a rule. A striking feature is that cordierite is often replaced by higher-pressure minerals, such as green biotite, muscovite, staurolite, andalusite, kyanite, garnet and ferrogedrite, testifying to a second, static, higher pressure phase of metamorphism (Kroonenberg, 1976). The pelitic gneisses are commonly associated with decimetre-sized bands or boudins of amphibolites, with hornblende and plagioclase as main minerals, and locally clinopyroxene, garnet or cummingtonite. They might correspond with metamorphosed basaltic sills or dykes, although trace element chemical data are lacking. Calcsilicate nodules with diopside, tremolite and andradite are common, and in one drill core dolomitic marble has been encountered. Furthermore intercalations of ferruginous, manganiferous and barium-rich quartzites and anthophyllitic ultramafic rocks have been found (Kroonenberg, 1976).

Possibly the two phases of metamorphism recorded in the cordierite-bearing pelitic gneisses correspond with the two age groups around 2.08-2.05 Ga and 1.99-1.98 Ga (Table 4), as in the two most thoroughly studied samples the cores of the zircons show the older age and the rims the younger metamorphic age. On the other hand it cannot be excluded that the older age represents detrital grains just like some still older zircon crystals in the same samples (see Fig. 12 and discussion below). Solving this dilemma requires detailed studies of individual zircon crystals, which is beyond the scope of the present paper.

\section{Dome Hill Gneiss}

In the area between the Coeroeni and Boven-Corantijn Rivers, culminating in the Dome Hill at $500 \mathrm{~m}$, as well as in the area around the confluence of those two rivers, migmatitic granulite-facies pelitic gneisses with coexisting sillimanite, garnet and cordierite are common, as well as intercalations of orthopyroxene-bearing amphibolites and pyribolites, locally with garnet. In contrast to the Bakhuis Granulite Belt, no orthopyroxene is found in the granulite-facies pelitic gneisses, so that the metamorphic conditions are definitely lower, maximum around $800^{\circ} \mathrm{C}$ and $6-8 \mathrm{kbar}$. Replacement of cordierite by 
Table 5. U-Pb and Pb-Pb geochronology of felsic metavolcanics and Younger Intrusives (for sample location see Fig. 4).

\begin{tabular}{|c|c|c|c|c|c|}
\hline Number on Fig. 4 & Sample number & Method & Age (Ma) & Rock & Reference \\
\hline 29 & Sur40 & $\mathrm{Pb}-\mathrm{Pb}$ & $1987 \pm 4$ & Felsic metavolcanic & De Roever et al. $(2010,2015)$ \\
\hline 30 & Sur48 & $\mathrm{Pb}-\mathrm{Pb}$ & $1980 \pm 4$ & Hypabyssal granite & De Roever et al. $(2010,2015)$ \\
\hline 31 & SU1 & $\mathrm{Pb}-\mathrm{Pb}$ & $1949 \pm 12$ & Biotite granite & De Roever et al. (2015) \\
\hline 32 & SB-21A & SHRIMP & $1980.2 \pm 5.8$ & Biotite granite & Cordani \& Fraga (unpublished) \\
\hline 33 & SB-21B & SHRIMP & $1961 \pm 20$ & Xenolith in 21A & Cordani \& Fraga (unpublished) \\
\hline 34 & GF1401/DDZ028 & $\mathrm{Pb}-\mathrm{Pb}$ & $1990 \pm 64$ & Microgranite & Lafon (2013) \\
\hline 35 & MW1225/DDZ031 & $\mathrm{Pb}-\mathrm{Pb}$ & $1974 \pm 2$ & Muscovite granite & Lafon (2013) \\
\hline 36 & ED 820/0B3820 & SHRIMP & $1982.9 \pm 9.0$ & Biotite Granite & De Roever et al. (2015) \\
\hline 37 & ED 631/0B3631 & SHRIMP & $1956.2 \pm 6.4$ & Biotite Granite & De Roever et al. (2015) \\
\hline 38 & KG789/DDZ025 & $\mathrm{Pb}-\mathrm{Pb}$ & $1985 \pm 2$ & Gabbro & Lafon (2013) \\
\hline 39 & ER117 & $\mathrm{Pb}-\mathrm{Pb}$ & $1980 \pm 5$ & Anorthosite & De Roever et al. (2003a) \\
\hline 40 & ER1109 & SHRIMP & $1984 \pm 4$ & Moi-Moi gabbro & Klaver et al. (2016) \\
\hline 41 & ER1115B & SHRIMP & $1971 \pm 15$ & Charlie gabbro & Klaver et al. (2016) \\
\hline 42 & MKS19 & U-Pb LA-ICP-MS & $1984.4 \pm 3.9$ & Charnockite & Klaver et al. (2015) \\
\hline 43 & MKS22 & U-Pb LA-ICP-MS & $1991.2 \pm 3.5$ & Charnockite & Klaver et al. (2015) \\
\hline 44 & MKS26 & U-Pb LA-ICP-MS & $1992.5 \pm 4.5$ & Charnockite & Klaver et al. (2015) \\
\hline 45 & MKS36 & U-Pb LA-ICP-MS & $1987.0 \pm 6.3$ & Charnockite & Klaver et al. (2015) \\
\hline 46 & MKS38 & U-Pb LA-ICP-MS & $1988.0 \pm 4.3$ & Charnockite & Klaver et al. (2015) \\
\hline
\end{tabular}

higher-pressure assemblages is rarely encountered (Kroonenberg, 1976).

\section{Felsic metavolcanics and younger intrusives}

The western half of Suriname outside the Bakhuis and Coeroeni metamorphic belts is occupied by a large granitoid-volcanic complex that is over 100 million years younger than the Older Granite in the east (Fig. 3, Table 1). The boundary between the two areas is therefore an important geotectonic marker, which will be discussed later in this paper. The complex consists of felsic metavolcanic rocks, principally meta-ignimbrites (Dalbana Formation), intruded by comagmatic subvolcanic leucogranites, granophyric granites and fine-grained granites (Sipaliwini Granite), muscovite granites (Coppename Muscovite Granite), and furthermore vast expanses of homogeneous varicoloured biotite granites, often with alkalifeldspar megacrysts (Wonotobo Granite). The intrusive relationships are evident from the contactmetamorphic recrystallisation of the metavolcanics in the vicinity of the intruding plutons, and metavolcanic xenoliths in the granites.

The metavolcanics and different types of granites mostly range in age between 1.99 and $1.98 \mathrm{Ga}$, and so are geochronologically indistinguishable. A few younger granites show ages of 1974, 1956 and 1949 Ma (Table 5). At the same time numerous small gabbroic-ultramafic plutons are dispersed throughout western Suriname, intruding not only the granitoid-volcanic complex, but also the Coeroeni and Bakhuis metamorphic belts.
Such a body at the mouth of the Lucie River gave $1985 \pm 4$ $\mathrm{Ma}$, suggesting that these Lucie Gabbro intrusions also form an integrated part of this huge magmatic pulse. The concentration of these intrusions in the southern Bakhuis Granulite Belt is particularly striking; the Moi-Moi gabbro in this area gave $1984 \mathrm{Ma}$, another very coarse-grained, almost pegmatitic one, the Charlie gabbro gave $1971 \mathrm{Ma}$ (Klaver et al., 2016). Finally, there are deep-seated charnockite and anorthosite intrusions within the Bakhuis Granulite Belt, which also give ages in the same range (Klaver et al., 2015, 2016).

This enormous magmatic province continues westwards into Guyana (Iwokrama metavolcanics and granites; Berrangé, 1977; Nadeau et al., 2013; Nadeau, 2014), Brazil (Surumu volcanics, Pedra Pintada granites; Reis et al., 2003, 2004; Fraga \& Dreher, 2010) and Venezuela (Caicará metavolcanics, Cuchivero granites; Cox et al., 1993; Wynn, 1993; Hackley et al., 2005), all with ages around 1.99-1.98 Ga (see Fig. 2). The widespread occurrence of similar metavolcanic and granitic rocks in the Guiana Shield has led to the concept of a huge magmatic province, the Uatumã province (Ramgrab \& Santos, 1974; Montalvão, 1975; Gibbs \& Barron, 1993 and references cited there). However, modern geochronological data show that there are at least two different age groups, one north of the CoeroeniCauarane belt (see Fig. 2) with ages around 1.99-1.96 Ga, and a younger one south of the Cauarane-Coeroeni belt (Jatapú and Iricoumé metavolcanics, Água Branca and Mapuera granites in Brazil, Kuyuwini in Guyana) with ages around 1.89$1.88 \mathrm{Ga}$ (Reis et al., 2000, 2014; Barreto et al., 2013, 2014; Marques et al., 2014). The latter group is not represented in Suriname. 


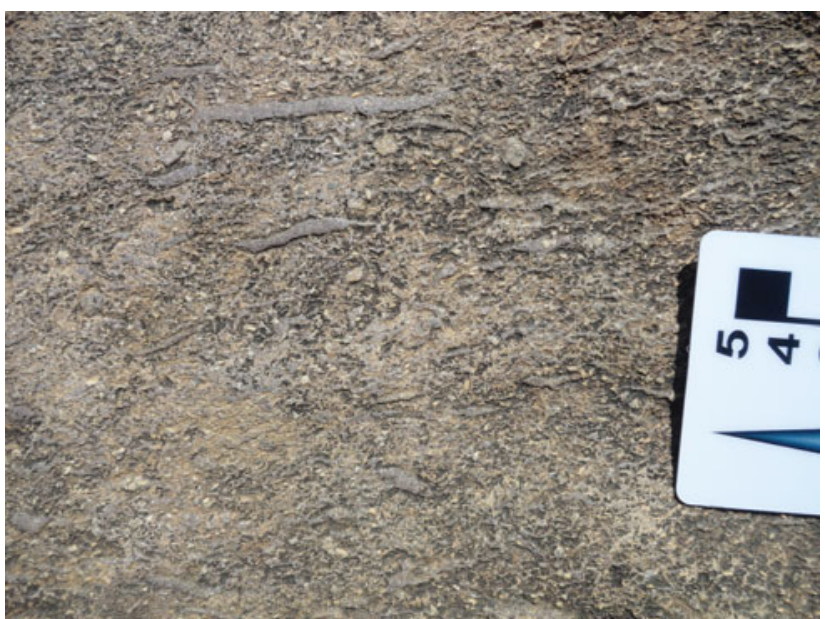

Fig. 13. Fiamme (collapsed pumice fragments) in felsic metavolcanics, Sipaliwini River. Scale in centimetres.

\section{Dalbana Formation}

Felsic metavolcanic rocks were designated Dalbana Formation by Bosma (1971). They have been described extensively by Verhofstad (1971) in the Wilhelmina Mountains in central Suriname. The most common rocks are grey, reddish or black metamorphosed rhyolitic ash-flow tuffs (ignimbrites), macroscopically characterised by fine lamination and fiamme, collapsed pumice fragments up to a few centimetres long (Fig. 13).

Microscopically flattened Y-shaped glass shards can sometimes be distinguished, but usually devitrification and lowgrade metamorphic recrystallisation to an extremely finegrained quartz-feldspar groundmass erased much of the fine microstructure of these rocks. Small alkali feldspar phenocrysts are often broken. Slightly more mafic metarhyodacites have mainly plagioclase and embayed HT quartz phenocrysts. The most mafic metavolcanics are metadacitic to meta-andesitic lavas with amphibole pseudomorphs after pyroxene. Geochemically the metavolcanics show $\mathrm{SiO}_{2}$ contents between $76 \%$ and $52 \%$, with $\mathrm{K}_{2} \mathrm{O} / \mathrm{Na}_{2} \mathrm{O}$ ratios varying between 0.70 and 2.10 (data from Verhofstad, 1971), and present a calcalkaline differentation trend (unpublished data by Bosma \& De Roever, 1975; De Vletter \& Kroonenberg, 1987; De Vletter et al., 1998; Delor et al., 2003b). Only the most acid metavolcanics with $\mathrm{SiO}_{2}>75 \%$ are slightly peraluminous, the others are metaluminous (data from Verhofstad, 1971). Close to granite the metavolcanics show a more advanced recrystallisation with a hornfelsic groundmass, testifying to the intrusive character of the granite plutons. The rocks show gentle, open folding, in contrast to the tight to isoclinal folding in the Marowijne Greenstone Belt metavolcanics. Reis et al. (2009) identified a possible caldera structure in the Serra Tepequem in the northern part of Roraima State, Brazil, which might have been a source of the Surumu-Dalbana felsic volcanics.

\section{Sipaliwini Leucogranite}

In close association with the metavolcanics three subvolcanic granite types are found, which were mapped separately on the 1977 map, but are here taken together: leucogranites, granophyric granites and fine-grained granites. By virtue of the contact metamorphism in the metavolcanics around these bodies they are considered to be slightly younger, but still comagmatic; they might correspond to the deeper substructures of the volcanoes that erupted the ignimbrites. In the Sipaliwini savanna they form conspicuous hills protruding above the plains underlain by the metavolcanics, such as the Vier Gebroeders Mountains (Maas \& Van der Lingen, 1975). They range in composition between alaskite-leucogranite and granite, and locally to granodiorite. Bluish quartz bipyramids are common phenocrysts, and granophyric intergrowths may form the bulk of the rock. Chemically they are slighty peraluminous, plot in the Syntectonic Collision Granite field in the discriminant $\mathrm{Rb} /(\mathrm{Yb}+\mathrm{Ta})$ diagram by Pearce et al. (1984) and have higher REE and more pronounced $\mathrm{Eu}$ anomalies than the Wonotobo biotite granites described below (De Vletter \& Kroonenberg, 1987).

\section{Wonotobo Granite}

The Wonotobo Granite is named after the impressive cataract in the Corantijn river where this granite crops out extensively (Bosma, 1969), which is also the site where the first biotite granite from West Suriname was dated by $\mathrm{Rb}-\mathrm{Sr}$ (Priem et al., 1968). In Guyana this granite was named WanatobaPakani Granite (Barron, 1965). This is the most common and widespread granite in western Suriname, characterised by medium to coarse grain size, variegated colour due to bluish quartz, greenish saussuritised plagioclase and pinkish alkali feldspar, the latter often as megacrysts up to $5 \mathrm{~cm}$ in size. Biotite is the common mafic mineral, hornblende occurs less frequently. In contrast to the older granites of eastern Suriname, these rocks are homogeneous, apart from the common occurrence of centimetre- to decimetre-sized rounded xenoliths of a variety of rocks, usually deformed and resorbed beyond recognition. These are I-type granitoids of monzogranitic composition.

\section{Coppename Muscovite Granite}

Muscovite granites are widespread in the upper Coppename and upper Saramacca areas, the contact zone between the Marowijne Greenstone Belt and the Older Granites in the east and the Younger Intrusives in the west. They are light-coloured, often pinkish S-type intrusive rocks of alkaligranitic to granitic composition with muscovite, usually also biotite, and commonly with aluminous minerals such as fibrolite, andalusite, cordierite or garnet (Verhofstad, 1971; Bosma \& Lokhorst, 1975; Bosma 
et al., 1984). Particularly in the Coppename area they are closely associated with Armina Formation metagreywackes, but also with Dalbana Formation felsic metavolcanics and subvolcanic leucogranites. Along the contacts between metagreywackes and granites hornfelses with andalusite, cordierite and fibrolite as well as staurolite-andalusite schists occur. Furthermore metapelitic, partly migmatitic gneisses occur in the same area, which may represent the higher-grade equivalents of the Armina Formation metagreywackes and metapelites (Arjomandi et al., 1973; Bosma \& Lokhorst, 1975). From a muscovite granite in southernmost Suriname, as well as on the border of the older and younger granites, a $\mathrm{Pb}-\mathrm{Pb}$ zircon age of $1974 \pm 2$ Ma was obtained (Table 5). This suggests that these muscovite granites are unrelated to the $>100$ Ma older Patamacca muscovite granites within the greenstone belt. Moreover, they do not show evidence of syntectonic intrusion, and have intruded at a higher crustal level than the Patamacca granites in view of the low-pressure mineral associations in the surrounding hornfelses and schists. They are related to the younger intrusives, and may have formed through the assimilation of Armina metasediments by leucogranites and biotite granites.

\section{Lucie Gabbro}

Throughout the country small gabbroic to ultramafic plutons have been found, which formerly were all considered to represent a single magmatic unit, called De Goeje Gabbro, after the De Goeje Mountains in the southeast of the country (GMD, 1977; Bosma et al., 1983, 1984). However, new geochronological data indicate that there are at least two different groups: the gabbroic-ultramafic intrusions within the greenstone belt, closely associated with the Paramaka metabasalts (Bemau Ultramafitite, see above), and the gabbroic intrusions outside the greenstone belt. The former were dated in French Guyana at 2147-2144 Ma on the Tampok gabbro, the physical continuation of the De Goeje gabbro body across the Marowijne River into that country (Delor et al., 2003a). From the gabbro body at the mouth of the Lucie River into the Corantijn River (Kroonenberg, 1976), far outside the greenstone belt, recently a $\mathrm{Pb}-\mathrm{Pb}$ age of $1985 \pm 2$ Ma was obtained (Table 5), ranging this suite of mafic plutons within the series of younger intrusives. We therefore abandoned the name De Goeje Gabbro altogether and designated the younger suite as Lucie Gabbro. In the older literature these bodies, although emplaced within granitoid areas, were thought to be older than the granites because of border effects, but geochronologically they are indistinguishable from the granites.

In the Bakhuis Granulite Belt many gabbroic bodies occur, especially in the area underlain by the Kabalebo Charnockites. Two of these bodies, the granoblastic Moi-Moi gabbro and the Charlie leucogabbro with cumulate texture, have recently been dated at $1984 \pm 4 \mathrm{Ma}$ and $1971 \pm 15 \mathrm{Ma}$ (Klaver et al., 2015, 2016), and so are geochronologically indistinguishable from the surrounding charnockites. Comagmatic metagabbro and metadolerite enclaves suggest contemporaneous emplacement of mafic and charnockitic melts. The mafic magmatism might have provided the heat source for charnockite emplacement (Klaver et al., 2015, 2016). Also in the area occupied by the Older Granites, especially near Pikien Rio pyroxene granites, there is a great amount of gabbroic intrusions, suggesting an affinity of these magmas to deep-seated environments, but whether the latter belong to Lucie Gabbro or Bemau Ultramafitite is unknown.

Many detailed descriptions of the Lucie Gabbro bodies exist, as they often form pronounced butterfly-shaped aeromagnetic anomalies, and were therefore targeted and drilled for base metal exploration, especially $\mathrm{Cu}, \mathrm{Ni}$ and $\mathrm{Cr}$ (Bosma, 1973b; Bosma \& Lokhorst, 1975; 0osterbaan, 1975). Their composition ranges from peridotite to pyroxenite to often hornblende- and biotite-bearing gabbronorite as a result of crystal fractionation (Bosma et al., 1984), and more felsic varieties occur as well. They are often referred to as metagabbronorite etc., although the metamorphic overprint is rather variable and often barely discernable; igneous cumulate textures usually predominate. A geochemical study of 117 samples from many different bodies (Bosma et al., 1980) showed that gabbronorites from deepseated environments in the Bakhuis belt and in the Pikien Rio pyroxene granite area are more tholeiitic in character, those from shallow-depth environments more calcalcaline. $\mathrm{Rb} /(\mathrm{Yb}+$ Ta) discriminant diagrams for a large number of gabbro bodies show a considerable scatter of values, and do not give reliable clues as to their tectonic environment. REE profiles show variable degrees of LREE enrichment and often positive Eu anomalies (Bosma et al., 1980).

\section{Kabalebo Charnockite}

In the southwestern part of the Bakhuis Granulite Belt a large intrusive body of charnockites occurs, ranging in composition from tonalite to granodiorite and granite (Klaver et al., 2015). In the field they are homogeneous magmatic rocks, without compositional banding. The mafic minerals are ortho- and clinopyroxene and biotite. In several places the charnockites show many xenoliths of mafic granulite and metadolerite. In the same area there are a large number of Lucie-type (meta)gabbro intrusions (Moi-Moi metagabbro), and contacts of charnockite with metagabbro have been observed in the field (Klaver et al., $2015,2016)$. Chemically the charnockites are magnesian, calcalkaline, metaluminous rocks with 56-74 wt\% $\mathrm{SiO}_{2}$, depleted in the mobile elements $\mathrm{Cs}, \mathrm{Rb}, \mathrm{U}$ and $\mathrm{Th}$, probably as a result of dehydration, and with high $\mathrm{TiO}_{2}, \mathrm{P}_{2} \mathrm{O}_{5}, \mathrm{~K}_{2} \mathrm{O}, \mathrm{Ba}$, REE and $\mathrm{Zr}$ contents compared to average granite (Klaver et al., 2015). Their chemistry suggests that they are the product of melting of the intermediate Bakhuis granulites (Klaver et al., 2015). Melting did not occur during or slightly after UHT metamorphism at 2.07-2.05 Ga, as the charnockites show ages of 1993-1984 
Ma, leaving a time gap of 60 Ma between UHT metamorphism and melting. There are no indications that UHT conditions continued during that interval. Intrusion of (meta)gabbro around 1.99-1.98 Ga produced a second pulse of extra heat-flow, leading to granulite melting (Klaver et al., 2016). The charnockites are coeval with the widespread felsic magmatism surrounding the Bakhuis Granulite Belt. However, the charnockites have a juvenile composition whereas the felsic metavolcanics may contain inherited Archean zircons (Nadeau et al., 2013) and show rather high Nd $\mathrm{T}_{\mathrm{DM}}$ model ages of 2.43-2.44 Ga (De Roever et al., 2015), which may indicate that they were derived from a different source (Klaver et al., 2015).

The Lucie type Moi-Moi metagabbro was dated at $1984 \pm$ $4 \mathrm{Ma}$, but another type of gabbro, the Charlie Gabbro, and dated at $1970 \pm 17 \mathrm{Ma}$, also occurs in the southwestpart of the BGB (Klaver et al., 2016). A rather large anorthosite body (Mozeskreek anorthosite) occurs in the centre of the BGB. It was dated at $1980 \pm 5 \mathrm{Ma}$ (De Roever et al., 2003a).

\section{Post-Trans-Amazonian rock units}

\section{Tafelberg Formation}

The Tafelberg Formation is the Surinam part of the Roraima Supergroup of Reis et al. (1990), Gibbs \& Barron (1993) and Santos et al. (2003). The Tafelberg is a horizontal sandstone plateau up to $1026 \mathrm{~m}$ in central Suriname and the easternmost outlier of the huge Roraima province that covers over $73,000 \mathrm{~km}^{2}$ in Venezuela, Guyana and Brazil (Gibbs \& Barron, 1993). In Suriname it consists of about $700 \mathrm{~m}$ of quartzarenites and quartz-rich well-sorted conglomerates, with at various levels thin red jasper-like indurated ash-fall tuffs (Bisschops, 1969). Sedimentary structures suggest deposition in an arid fluviodeltaic environment (Bisschops, 1969; Bosma et al., 1983, 1984; De Vletter et al., 1998), but no detailed sedimentological study has been made. A smaller occurrence is in the Emma Range west of the Tafelberg. The sandstones unconformably overlie Wonotobo-type biotite granite and Sipaliwini Leucogranites and is intruded by Avanavero Dolerite dykes. The basal contact is marked by a reddish paleosol (Fig. 14; Kroonenberg, 1978). Priem et al. (1973) obtained a Rb-Sr isochron age of $1655 \pm 18 \mathrm{Ma}$ for the volcanic ashes. Modern zircon U-Pb data from volcanic ashes from the Pakaraima Plateau in Brazil give a Paleoproterozoic age of $1873 \pm 3 \mathrm{Ma}$, while baddeleyite and zircon from two intruding Avanavero sills gave $1782 \pm 3$ $\mathrm{Ma}$ (Santos et al., 2003). However, the presence of multiple ash falls with a range of ages cannot be excluded, and therefore new geochronological data from Tafelberg are needed.

Reis et al. (1990) give a synthesis of the stratigraphy and depositional environments of the Roraima Supergroup in Brazil, and Beyer et al. (2015) in Guyana. Paleocurrent analyses of Roraima rocks in Brazil show provenance from the north, and most

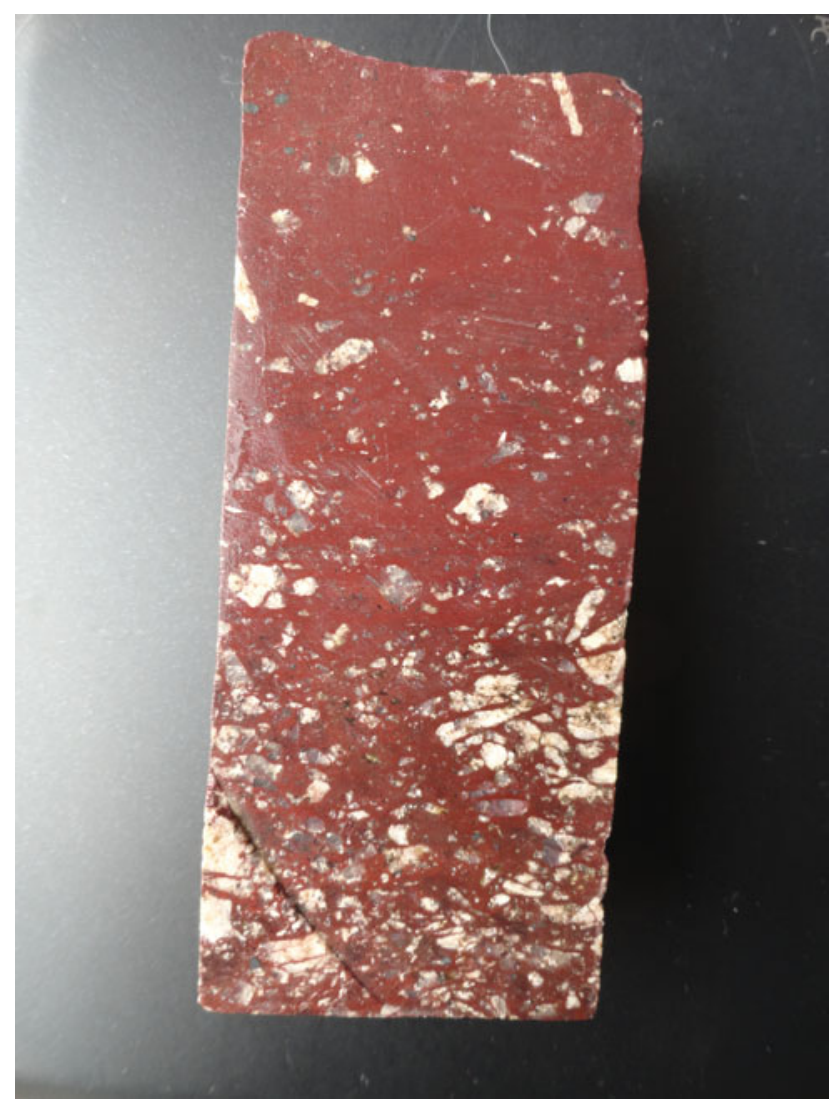

Fig. 14. Paleosol near base of Tafelberg Formation, Elfriedeval, Tafelberg. Core diameter $4 \mathrm{~cm}$.

detrital zircons show ages between 2171 and 1958 Ma, suggesting that Trans-Amazonian rocks formed the main source of the sediments (Santos et al., 2003). The Roraima Supergroup therefore can be considered as the molasse of the Trans-Amazonian Orogeny. The source of the ash-fall tuffs is unknown, but in view of the very large area in which they are dispersed they must represent tremendous eruptions. Along the southern border of the Guiana Shield in Brazil the Iricoumé volcanics and associated granitic intrusions of 1.89-1.81 Ga (Valério et al., 2012; Marques et al., 2014; Barreto et al., 2013; Fig. 2) have the right age and composition to produce the Roraima ash layers, and caldera-like structures have been documented from the Pitinga mining district (Pierosan et al., 2011). From Tafelberg no new geochronological data are available.

\section{Avanavero Dolerite}

Conspicuous mafic dykes of $50 \mathrm{~m}$ to $1 \mathrm{~km}$ in thickness cut all previously described geological units, and often stand out topographically as laterite-capped elongated ridges over $100 \mathrm{~km}$ long, such as the Van Asch van Wijck Mountains (GMD, 1977; Bosma et al., 1983, 1984). Many dykes have a NE-SW orientation, but other bodies form irregular masses or sills. They also intrude the Roraima Supergroup at Tafelberg and elsewhere in 
Guyana, Venezuela and Brazil. They were named Avanavero Dolerite, after the Avanavero Falls in the Kabalebo River (Loemban Tobing, 1969), and this name has been adopted in all the neighbouring countries (Reis et al., 2013). They are characterised by the presence of two pyroxenes, Ca-rich augite and Ca-poor inverted pigeonite, the latter expressed as orthopyroxene with exsolution lamellae of clinopyroxene.

Chemically they are mainly tholeiitic basalts with high Cs, $\mathrm{Rb}, \mathrm{Ba}$ and $\mathrm{K}$ and low $\mathrm{Nb}$ contents, suggesting a lithospheric mantle source, modified by crustal contamination and/or by variable enrichment with slab fluids or melt from oceanic lithosphere (De Roever et al., 2003b; Reis et al., 2013). The REE patterns are generally LREE-enriched $(\sim 20-70 \times$ relative to chondrites), compared to the HREE (7-17 $\times)$, with no or only slight negative Eu anomaly (Reis et al., 2013). The most precise age obtained so far is $1794.5 \pm 1.6 \mathrm{Ma}$ (MSWD $=0.2$ ) on baddeleyite from the Pedra Preta Sill in Roraima State, Brazil (Reis et al., 2013), which closely matches earlier values from the 0mai mine in Guyana (Norcross et al., 2000) and the Cipó sill in Brazil (Santos et al., 2003; Reis et al., 2013). The Avanavero Dolerite is suggested to form part of a mafic Large Igneous Province (LIP) of continental scale, stretching over $300,000 \mathrm{~km}^{2}$ and representing a magma volume of at least $30,000 \mathrm{~km}^{3}$ (Gibbs \& Barron, 1993; Reis et al., 2013). The preferential NE-SW orientation suggests an episode of continental rifting, although its precise geotectonic significance is not clear.

\section{Käyser Dolerite}

A separate suite of NW-SE oriented narrow dolerite dykes was discovered in southwest Suriname, stretching over a distance of $300 \mathrm{~km}$ from the Sipaliwini area through the Käyser Mountains to the Kabalebo and Corantijn areas (Bosma et al., 1983, 1984; De Roever et al., 2003b). It differs strongly from the Avanavero and Apatoe dolerites in mineralogy, chemistry and age. It is characterised by abundant fresh olivine, titaniferous augite, biotite and minor kaersutite as mafic minerals. Chemically it is alkalibasaltic in composition instead of tholeiitic as the other suites, with $\mathrm{Na}_{2} \mathrm{O}+\mathrm{K}_{2} \mathrm{O}$ up to $4.5-6.5 \%$ at $\mathrm{SiO}_{2}$ contents of $43-50 \%$, and also in various geochemical discriminant diagrams it plots in the alkalibasalt field (De Roever et al., 2003b). REE patterns show a marked fractionation, with $\mathrm{La}_{\mathrm{N}} / \mathrm{Yb}_{\mathrm{N}}$ values of 6.9-8.2. Ar-Ar dating of biotites of a sample from the Westrivier (point 47 in Fig. 4) show plateau ages of $1501 \pm 5 \mathrm{Ma}$, which is taken as the age of their crystallisation (De Roever et al., 2003b). This might reflect an event of continental extension in the Guiana Shield, although the nearest coeval rocks are the anorogenic Mucajaí and Surucucus rapakivi granites in Roraima State in Brazil, the Parguaza rapakivi granites in Venezuela and the Mitú granites in the Colombian Amazones (De Roever et al., 2003b; Kroonenberg \& Reeves, 2012; Reis et al., 2003; Bonilla-Pérez et al., 2013 and references cited there).

\section{Nickerie Mylonite}

Shearing and mylonitisation along major NE-SW fault zones affected large areas of the western Surinam basement, as well along the Imataca Granulite Belt in Venezuela. Mylonites and pseudotachylites are particularly prominent along the border faults of the Bakhuis horst in western Suriname. Low-grade metamorphic recrystallisation up to the pumpellyite-prehnite or greenschist facies is common. At the same time, many TransAmazonian rocks of different units in the western part of the country show thermal resetting of their $\mathrm{Rb}-\mathrm{Sr}$ and $\mathrm{K}-\mathrm{Ar}$ mineral ages in the range of 1100-1300 Ma; the combined effects were termed Nickerie Metamorphic Episode by Priem et al. (1968, 1971). In Guyana it has been defined by Barron (1969) as K'Mudku Episode, a term adopted also by Brazilian geologists (Cordani et al., 2010), although Gibbs \& Barron (1993) prefer Nickerie. Mineral age resetting is restricted to western Suriname in the (former) Nickerie District, in the eastern part of the country mineral ages are Trans-Amazonian. These effects have been attributed to the Grenvillian Laurentia-Amazonia collision around 1100-1000 Ma along the western border of the Guiana Shield (Kroonenberg, 1982, 1994; Cordani et al., 2010).

\section{Muri Alkaline Complex}

The Muri Alkaline Complex occupies a small isolated mountain range in the extreme southwest of the area, straddling the boundary between Suriname and Brazil between the headwaters of the Coeroeni and Boven Corantijn Rivers. It was discovered during the Radambrasil campaign and then called Sienito $\mathrm{Mu}-$ tum (Issler et al., 1975), and it was explored in the 1980s by the UN Revolving Fund for Natural Resources Exploration (Fozzard, 1986). It consists of two adjacent nepheline syenite and tinguaite bodies intruding into biotite granodiorite. A conical hill next to the northeastern body, Twareitau, is believed to be underlain by carbonatite. The laterite cap on top is high in $\mathrm{Nb}$ and $\mathrm{Sr}$, the soil below it shows a high radioactive anomaly and is rich in REE-phosphates, and the rivers draining it have a $\mathrm{pH}$ of 8.5. Fenitisation (Na metasomatism) affected rocks in the surroundings (Barron, 1981; Premoli \& Kroonenberg, 1984; Fozzard, 1986; Gibbs \& Barron, 1993). Issler et al. (1975) provided a K-Ar age on perthite of $1026 \pm 28 \mathrm{Ma}$, while Nadeau (2014) gives an age of $1090 \mathrm{Ma}$. Cordani et al. (2010) suggest that the alkaline magmatism took advantage of the $\mathrm{K}^{\prime} \mathrm{Mudku} /$ Nickerie shear zones caused by the Grenvillian orogeny. Bosma et al. (1984) report a $1.5 \mathrm{~m}$ wide, undeformed analcime-nephelinebearing monchiquite dyke in western Suriname, without further details.

\section{Apatoe Dolerite}

A third generation of dyke swarms of Early Jurassic age with a general N-S orientation transects the basement in large parts 
of the country, called Apatoe after the Apatou village on the French Guiana bank of the Marowijne River, where a dyke swarm crosses the river. They are usually not more than $50 \mathrm{~m}$ wide, but nevertheless are often expressed in the topography as parallel narrow laterite-capped ridges and can be followed for over 300 $\mathrm{km}$. They consist of pigeonite dolerite with only rarely olivine and no orthopyroxene, and are completely fresh. Nomade et al. (2000) report a bulk plagioclase $\mathrm{K}-\mathrm{Ar}$ age of $196.0 \pm 1.7 \mathrm{Ma}$ for the Apatoe dolerite at the type locality, and Nomade et al. (2007) show a major peak of mafic dyke emplacement in the eastern Guiana Shield around 198 Ma.

Chemically they are Fe-enriched tholeiites and have higher $\mathrm{Zr}$ than either Avanavero or Käyser dolerites, whereas their Sr and Ti contents are intermediate between those (Bosma et al., 1984; De Roever et al., 2003b; Deckart et al., 2005). REE diagrams show slight enrichment of LREE $\left(\mathrm{La}_{\mathrm{N}} / \mathrm{Yb}_{\mathrm{N}}\right.$ 1.49-5.09) and virtually no $\mathrm{Eu}$ anomalies, spider diagrams show positive to negative $\mathrm{Sr}$ anomalies and a slight positive $\mathrm{Ti}$ anomaly. The $\mathrm{Nd}-\mathrm{Sr}$ isotope signatures point to depleted mantle sources with little crustal contamination (Deckart et al., 2005). The Apatoe Dolerite forms part of the Jurassic Central Atlantic Magmatic Province, which heralds the separation of the American continents from Africa and Eurasia and the origin of the Atlantic Ocean as parts of the breakup of Gondwana (Deckart et al., 2005; Nomade et al., 2007).

\section{Discussion}

Two alternative scenarios are considered for the geological evolution of the Proterozoic basement of Suriname. The first scenario supposes that the greenstone belt, the high-grade belts as well as the extensive granitoid-volcanic magmatism are all a consequence of the Trans-Amazonian Orogeny triggered by subduction from the north and final collision of the Guiana Shield with the West African Craton (cf. Table 1).

In the second scenario favoured by Fraga et al. (2008, $2009 a, b)$, the formation of the Cauarane-Coeroeni Belt belt is the result of subduction from the south and finally collision with a continent that should be located largely in the Brazilian part of the Guiana Shield. The ensuing magmatism is considered to be post-orogenic. We will discuss the three phases of the first scenario below, and then revert to the alternative scenario.

\section{Trans-Amazonian Phase I (2.18-2.09 Ga)}

The development of the Marowijne Greenstone Belt is generally seen as the first stage in the convergence and ultimately collision between the Amazonian Craton and the West African Craton (Ledru et al., 1994). This phase corresponds with the Main Trans-Amazonian Event of Delor et al. (2003a) in French Guiana. The nature and the paleogeographic position of the colliding cratons is still very uncertain, as only a few remnants of a pre-Trans-Amazonian crust are known in the Guiana Shield. Sr and Nd isotope data from the greenstone belt in French Guiana indicate that they all are juvenile rocks without any contribution of Archean crust, with the possible exception of Armina Formation metapelites (Delor et al., 2003a,b). No Archean detrital zircons have been found so far in the greenstone belt.

Only at the western and eastern extremities of the Guiana Shield do domains of Archean rocks occur. In the Imataca belt in western Venezuela, SHRIMP data on zircon cores from the granulites show Archean protolith ages up to 3.2 Ga, but the 2.2-2.0 Ga metamorphic overgrowths of the zircons suggest that highgrade metamorphism was Trans-Amazonian and hence more or less coeval with that of the Bakhuis and Coeroeni belts (Tassinari et al., 2004a,b). In a pre-drift reconstruction the Imataca belt lines up with the Man craton in West-Africa, and the Guri fault can be followed as well (Fig. 15; Nomade et al., 2003; Cordani \& Teixeira, 2007; Bispo-Santos et al., 2014). The westernmost part of the northern Guiana greenstone belt in Venezuela abuts onto the Archean Imataca Granulite Belt along the Guri fault. However, recent research suggests that the greenstone belt in Venezuela is allochthonous with respect to the Imataca belt and has been emplaced on top of it by thrust faulting (Hildebrand et al., 2014).

The other Archean terrain in the Guiana Shield, the Amapá Block in the southeastern extremity of the Guiana Shield in Brazil, also shows Archean protolith ages and Trans-Amazonian granulite-facies metamorphism around 2.10-2.08 Ma (RosaCosta et al., 2003, 2006, 2009). Archean detrital zircons have been found in the Coeroeni Gneiss Belt (De Roever et al., 2010, 2015), and in Guyana even a Hadean zircon xenocryst with a U$\mathrm{Pb}$ zircon age of $4219 \pm 19$ Ma was found in the Toka granite of the Iwokrama Formation, equivalent to the Dalbana Formation metavolcanics and their intrusive counterparts (Nadeau et al., 2013; Nadeau, 2014).

Whatever the position and fate of the Archean continents, the main phase of the Trans-Amazonian Orogeny starts at its earliest around $2.26 \mathrm{Ga}$ with the formation of tholeiitic gabbros of mid-oceanic ridge or back-arc-basin origin in the Île de Cayenne in French Guiana, on the basis of recent zircon U-Pb dates and Sm-Nd data (Vanderhaeghe et al., 1998; Delor et al., 2003a,b) and in the Ipitinga greenstone in Amapá (McReath $\&$ Faraco, 2006). This early event has not yet been recognised with certainty in Suriname, but the tholeiitic metabasalts of the Paramaka Formation might belong to the same stage of oceanic crust formation. Convergence of the two continents leads to southward subduction of oceanic crust and diapiric intrusion of TTG bodies around $2.18 \mathrm{Ga}$ in French Guiana, and by analogy also in Suriname, continuing to about $2.13 \mathrm{Ga}$ (Delor et al., 2003a,b). In the same time interval, between 2156 and $2137 \mathrm{Ma}$, calcalkaline island-arc volcanism starts to develop, leading to the andesitic to rhyolitic suites of the Paramaka Formation, as well as to submarine deposition of chemical sediments. Part of the volcanic arc emerges soon, as is shown by the Paramaka 


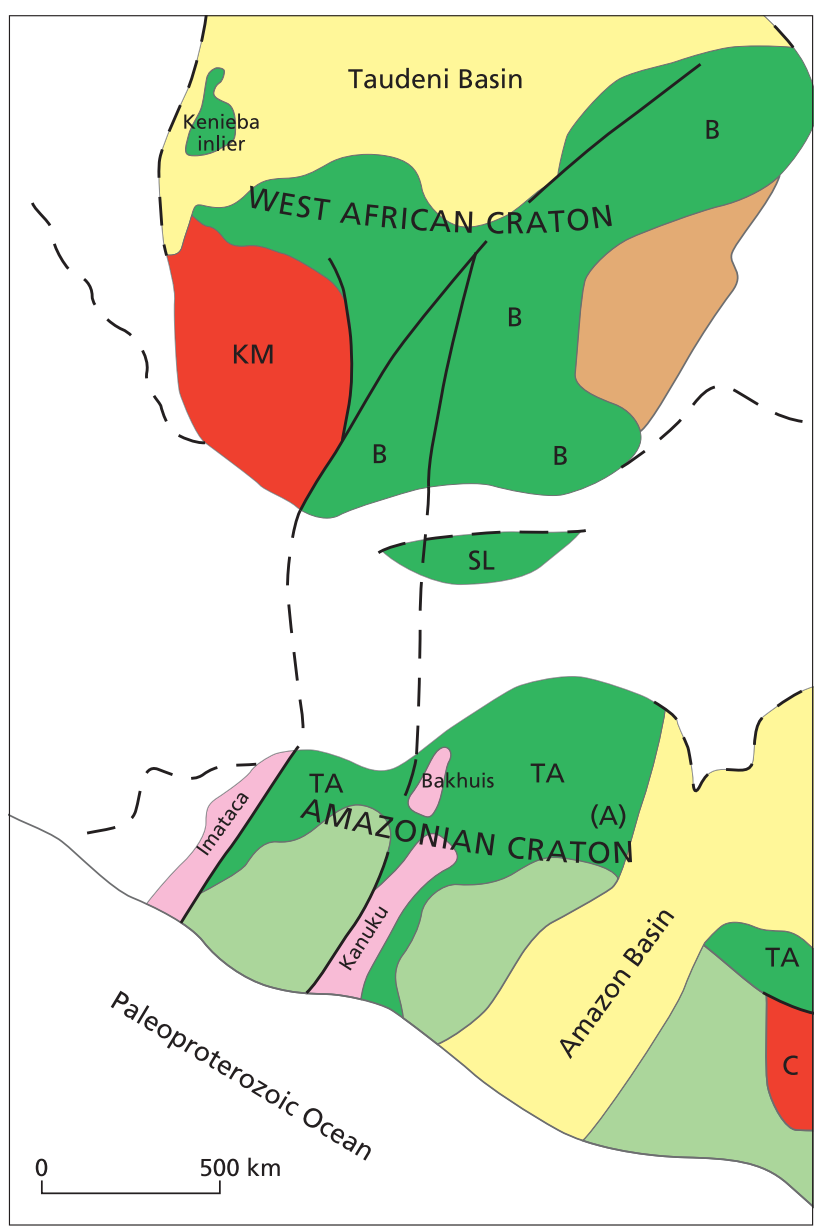

\footnotetext{
Archean

C Carajas granite greenstone terrain

Kenema -Man Block

Paleoproterozoic

$\square$ Younger Paleoproterozoic Rocks

B Birrimian greenstone belt

TA Trans-Amazonian greenstone belt

Sao Luis cratonic fragment

High grade basement complexes

Neoproterozoic

Volta Basin

Phanerozoic

$\square$ Sedimentary covers
}

Fig. 15. Sketch map of the correlation of the eastern half of the Guiana Shield with the West African Craton. Modified after Cordani \& Teixeira (2007), adapted from Nomade et al. (2003).

volcanic and TTG lithic clasts in the Armina Formation greywackes deposited by turbidity currents after $2127 \mathrm{Ma}$ (Daoust et al., 2011; Naipal \& Kroonenberg, 2016). On the other hand, the metapelites of the Armina Formation are the only rocks in the greenstone belt that show some Archean inheritance on the basis of Sm-Nd isotopic data. The Bemau Ultramafitite intrudes into the Paramaka volcanics in the same time interval, and on both outer sides of the greenstone belt coeval Sara's Lust gneiss complexes testify of incipient anatexis in the deeper part of the greenstone belt. Tight to isoclinal folding and low-grade metamorphism in this stage are referred to as deformation phase D1 by Delor et al. (2003a,b) and Daoust et al. (2011).

A second tectonic pulse within the first phase of the TransAmazonian Orogeny is evidenced by the Rosebel Formation meta-arenites. Within the greenstone belt new basins are being formed, both in Suriname and French Guiana, in which the fluvial Rosebel Formation is deposited unconformably on pre-existing rocks. Delor et al. $(2003 a, b)$ in French Guiana and Daoust et al. (2011) in Suriname attribute this to a change in tectonic style, in which sinistral shearing related to oblique plate convergence leads to the formation of pull-apart basins between 2.11 and $2.08 \mathrm{Ga}$. This deformation phase is referred to as D2a (Vanderhaeghe et al., 1998; Delor et al., 2003a,b; Daoust et al., 2011). This pulse also leads to extensive anatexis and intrusion of metaluminous deep-seated granites, in Suriname evidenced by the Gran Rio Biotite Granite and the Pikien Rio Pyroxene Granite around 2.10-2.09 Ga, as well as to the intrusion of the Patamacca Two-Mica Granite into the Armina Formation metagreywackes with their Taffra Schist aureoles. Delor et al. (2003a,b) in French Guiana and Daoust et al. (2011) in Suriname distinguish a third deformation phase in the greenstone belt around 2.07-2.06 Ga, allegedly caused by a local change to dextral shearing (deformation phase D2b), which caused metamorphism of the Rosebel arenites and is responsible for most of the quartz veins with gold mineralisation in the Rosebel Gold Mines. We discuss events in that time interval in the next section.

\section{Trans-Amazonian Orogeny Phase II (2.07-2.05 Ga)}

The Bakhuis Granulite Belt, the Coeroeni Gneiss Belt, the coeval rocks of the Kanuku Complex in Guyana and the Cauarane Group in the Roraima State of Brazil constitute a high-grade belt of over $1000 \mathrm{~km}$ in length, earlier defined as Central Guiana Granulite Belt by Kroonenberg (1976). It matches the Guiana Shield greenstone belt in size. Its rough parallellism with the greenstone belt to the north and the age of its main phase of metamorphism between 2.07 and 2.05 Ga suggest that it forms an integral, although younger, stage of the Trans-Amazonian Orogeny, even though the Bakhuis horst diverges from the main E-W trend of the belt and intersects the greenstone belt in western Suriname. However, the tectonic significance of the Central Guiana Granulite Belt is still very much debated.

The first question that has to be solved is the tectonic setting of the basin in which the sedimentary-volcanic protoliths of the high-grade rocks were deposited. This requires consideration of its metamorphic history. The Coeroeni and Bakhuis belts have been affected by a first stage of high-grade metamorphism between 2.07 and $2.05 \mathrm{Ga}$, in which cordierite is a stable phase in the metapelites. In a later stage, dated in Coeroeni around $1.98 \mathrm{Ga}$, cordierite in both belts was replaced by higher-pressure assemblages or at least following an isobaric cooling path (Kroonenberg, 1975, 1976; De Roever, 1975; De Roever et al., 2003a; 
Klaver et al., 2015), defining an anticlockwise metamorphic history (cf. Harley, 1989). This phenomenon was also noted from the Kanuku Complex in Guyana (e.g. Singh, 1966; Plate $27 \mathrm{~B}$, and own unpublished observations of cordierite replaced by sillimanite, andalusite and green biotite in gneiss from the Upper Kuyuwini River), and is reported from the Cauarane belt in Brazil as well by Dreher et al. (2009).

Such an anticlockwise history is uncommon in collisional orogenic belts and therefore basin formation is unlikely to have taken place in a normal active plate margin configuration. Continental collision produces clockwise metamorphic histories: first high pressure and low temperature metamorphism as a result of crustal thickening, and then heating as a result of rising isotherms. Anticlockwise metamorphism, and especially the UHT metamorphism in the Bakhuis Granulite Belt, on the other hand, requires initial presence of an extra heat source, followed by a higher pressure event or isobaric cooling path (Harley, 1989; Touret \& Huizenga, 2012).

Delor et al. (2003a,b), De Roever et al. (2003a) and Klaver et al. (2015) suggest that crustal thinning and mantle upwelling can produce the necessary extra heat. This seems a plausible hypothesis in itself. Delor et al. $(2003 a, b)$ suggest that the three genuine granulite belts Imataca, Bakhuis and Amapá constitute a kind of continental-scale 'pinch and swell' structure, with two E-W greenstone-TTG 'boudins' limited by the three granulite domains, triggered by oblique continent collision and opening of pull-apart basins in which the granulite protoliths would have been deposited and heat provided by upwelling mantle material produced the UHT metamorphism. This is supposed to be the first step in their Late Trans-Amazonian Orogenic Event. However, the Cauarane-Coeroeni Belt with a similar metamorphic history as the Bakhuis Belt runs parallel to the greenstone belt and therefore does not fit into the oblique collision scenario.

There are several other possible scenarios involving mantle upwelling as a heat source for the anticlockwise metamorphic history of UHT metamorphic belts, such as post-orogenic slab break-off and ridge subduction, as discussed by Santosh et al. (2012) for a similar case in the Paleoproterozoic of the North China Craton. We therefore prefer to envisage an ascending mantle plume at the site where the Bakhuis, Coeroeni and Kanuku belts meet, for instance triggered by a synorogenic Trans-Amazonian slab break-off (cf. Klaver et al., 2015), causing triple-junction rifting and aulacogene-type basin formation, followed by volcanism, marine sedimentation and highheatflow metamorphism in its deepest parts. The mafic granulites and metadolerite dykes in the Bakhuis belt, and possibly part of the amphibolites in the Coeroeni belt, might testify to magma ascent during the rifting event. Subsequent advance of the Trans-Amazonian tectonic front could have closed the rifts and caused the second phase of higher-pressure metamorphism around $1.98 \mathrm{Ga}$. A comparable history has been reconstructed for the anticlockwise UHT metamorphism in the Paleozoic Chinese Altai of the Central Asian Orogenic Belt (Tong et al., 2014).
Trans-Amazonian Orogeny Phase III (1.99-1.95 Ga)

In the interval of 1.99-1.98 Ma the whole western part of Suriname becomes affected by intense magmatism of greatly varying composition and emplacement depth. In the Bakhuis Granulite Belt, the Kabalebo charnockites intrude at great depth into the granulites, possibly contemporaneously with the second, static phase of metamorphism replacing cordierite, although the age of the latter event has not yet been confirmed geochronologically. Klaver et al. (2015) argue that in order to be able to generate charnockitic magma this second phase should also have UHT characteristics, although this has not yet been confirmed geochronologically. In that same area there is a striking concentration of mafic intrusives, which might have generated the extra heat required to produce the charnockite magmas (Klaver et al., 2015, 2016). The second phase of metamorphism in the Coeroeni Gneiss Belt has been dated convincingly around $1.98 \mathrm{Ga}$, roughly contemporaneous with local intrusion of mafic Lucie Gabbro magmas. A few slightly younger granite intrusives show ages down to $1.95 \mathrm{Ga}$ (see above).

At the same time, enormous volumes of felsic magma erupt as Dalbana Formation ash-flow tuffs across large areas in western Suriname, or intrude at shallow crustal depth as Sipaliwini Leucogranite, or slightly deeper as Wonotobo Granite, and become pierced by small Lucie Gabbro intrusives. This magmatic province is part of the shield-wide belt described before, stretching W-E from the Caicara volcanics in Venezuela through the Surumu volcanics of Brazil, the Iwokrama volcanics of Guyana into Suriname, between the Cauarane-Coeroeni Belt and the greenstone belt, and interrupted by the Bakhuis Granulite Belt (Fig. 2).

On the basis of the position of this felsic granitoid-volcanic belt parallel to the greenstone belt, its calc-alkaline nature and syntectonic collision trace-element geochemistry as well as its age between 1.99 and $1.96 \mathrm{Ga}$ suggest that these rocks intruded in a late stage of the Trans-Amazonian 0rogeny, in harmony with Berrangé (1977), Bosma et al. (1983, 1984) and Delor et al. (2003b). The extensive magmatism at the end of the Trans-Amazonian Orogeny may be attributed to underplating of large quantities of mafic magma, producing the heat source for the generation of charnockitic magma and the emplacement of the numerous Lucie Gabbro plutons, as well as extensive crustal melting to generate the felsic volcanism.

Recent paleomagnetic work shows that the Apparent Polar Wandering Paths of the Amazonian Craton and West African Craton still differ in the period 2080-2040 Ma (Trans-Amazonian second phase), but coincide between 2000 and 1980 Ma (TransAmazonian third phase), putting the Guri Fault in Venezuela in line with its West African counterpart the Sassandra fault (Nomade et al., 2003; Bispo-Santos et al., 2014). This major event apparently formed the culmination of the West AfricaAmazonia collision, and might be held responsible for the 
massive magmatic pulse in the last phase of the TransAmazonian Orogeny.

\section{An alternative scenario}

An alternative scenario is presented by Fraga et al. (2008, 2009a,b, 2011). The Cauarane-Coeroeni high-grade belt (Fig. 2) divides the Guiana Shield in two entirely different domains (Fraga et al., 2008, 2009a,b). The domain north of it is characterised by the 2.26-2.09 Ga TTG-greenstone belt and the Archean Imataca and Amapá blocks. In this scenario the Bakhuis Granulite Belt is not a part of the Cauarane-Coeroeni Belt, but belongs to this northern domain and is considered as older Rhyacian terrain partially recycled around $2.06 \mathrm{Ga}$. The area south of the Cauarane-Coeroeni Belt is an entirely different domain, consisting of Iricoumé-Jatapu ('Uatumã') volcanic and intrusive rock units younger than $1.88 \mathrm{Ga}$ (Fig. 2) or older crust that has been obliterated by extensive felsic plutonism and volcanism in the 1.89-1.81 Ga event, according to Fraga et al. (2009a).

In Roraima State in Brazil, south of the Cauarane-Coeroeni Belt, fragments of 2.04-2.03 Ga (meta-)igneous older crust have been found in the Trairão and Anauá complexes (too small to be represented on Fig. 2, but incorporated in the UraricoeraUrubu unit), which were interpreted as remnants of magmatic arcs (Fraga et al., 2009a, 2011). The Trairão rocks are compositionally banded diorites, granodiorites and tonalites, the banding being expressed by aligned magmatically zoned plagioclase crystals. They show a U-Pb SHRIMP zircon age of 2026 $\pm 5 \mathrm{Ma}$ and a U-Pb LA-MC-ICPMS zircon age of $2044 \pm 17 \mathrm{Ma}$. $\mathrm{T}_{\mathrm{DM}}$ model ages vary between $2091 \mathrm{Ma}$ and $2024 \mathrm{Ma}$, with $\mathrm{C}_{\mathrm{Nd}(\mathrm{t})}$ values between +2.2 and +3.0 , indicating juvenile sources or at least with a limited crustal residence. Similar rocks from the Anauá complex show a U-Pb SHRIMP age of $2028 \pm 9$ Ma (Fraga et al., 2011).

The Cauarane-Coeroeni Belt, in this view, started as an active continental margin at the southern border of the Rhyacian continent, and records the northwards collision around $2.00 \mathrm{Ga}$ of the Anauá-Trairão magmatic arcs with the older Rhyacian crust. The age of this collision is bracketed by the $2.038 \mathrm{Ga}$ U$\mathrm{Pb}$ SHRIMP age for a detrital zircon from a Cauarane paragneiss, and the presence of a large Cauarane xenolith in a $1.98 \mathrm{Ga}$ I-type Pedra Pintada granitoid pluton in Roraima State. The extensive Surumu-Dalbana volcanism and plutonism north of the Cauarane-Coeroeni Belt around 1.98-1.96 Ga records postorogenic I- and A-type magmatism (Fraga et al., 2008, 2009a,b), and is therefore unrelated to the Trans-Amazonian Orogeny.

\section{Post-Trans-Amazonian events}

The Tafelberg Formation of the 1.87 Ga Roraima Supergroup represents the demise of the Trans-Amazonian mountain chain and deposition of its molasse in a fluvial sedimentary basin, now a striking example of relief inversion. Later crustal extension is exemplified by widespread intrusion of the mafic Avanavero (1.79-178 Ga) and Käyser (1.50 Ga) dykes.

Beyond the borders of Suriname the post-Trans-Amazonian development of the Guiana Shield continued in the south by a younger phase of extensive felsic magmatism in the IricouméJatapú belt (1.89-1.81 Ga) (Fig. 2). Sm-Nd systematics in this belt do not show any trace of an Archean inheritance (Barreto et al., 2014), which contradicts the earlier concept of Tassinari \& Macambira (1999) and Santos et al. $(2000,2006)$ that this 'Central Amazonian Province' would be the core around which continental accretion of the Amazonian craton could have started, and also contradicts the idea by Fraga et al. $(2009 a, b)$ that this magmatism obliterated older crust. However, the undifferentiated Tumucumaque basement in this area (Fig. 2) is still very poorly studied.

Along the western margin of the Guiana Shield the Rio Negro Belt, consisting mainly of amphibolite-facies migmatitic gneisses dated between 1.86 and $1.72 \mathrm{Ga}$, was accreted (Tassinari, 1981; Tassinari et al., 1996; Tassinari \& Macambira, 1999; Cordani \& Teixeira, 2007; Ibáñez-Mejía et al., 2011; Kroonenberg \& Reeves, 2012), although an obvious suture has not been found. However, this area has been very poorly studied, especially the undifferentiated basement in southern Venezuela (Fig. 2). In the Mesoproterozoic extensive anorogenic magmatism affected the whole western part of the Guiana Shield (Dall'Agnol et al., 1999; Kroonenberg \& De Roever, 2010).

The last accretion to the western margin of the Guiana Shield is the Grenvillian Garzón-Santa Marta belt in the Colombian Andes, caused by the collision of Laurentia and Amazonia between 1200 and $1000 \mathrm{Ma}$ (Kroonenberg, 1982; Hoffmann, 1991;Tohver et al., 2006; Cordani et al., 2010; Ibáñez-Mejía et al., 2011). This event left its traces in Suriname as the Nickerie Mylonite, evidenced by extensive shearing, mylonitisation and thermal age resetting of micas and amphiboles (Priem et al., 1971), as well as punctuated alkaline magmatism such as the Muri alkaline complex (Fozzard, 1986; Cordani et al., 2010).

\section{Conclusions}

The Paleoproterozoic Basement of Suriname was essentially formed during three successive stages of the Trans-Amazonian Orogeny between 2.26 and $1.98 \mathrm{Ga}$, each acting in parallel, approximately E-W running belts across the whole northern Guiana Shield.

In the first stage between 2.26 and $2.09 \mathrm{Ga}$ convergence and ultimately collision between as yet elusive Archean Amazonian and West African cratons led to the formation of juvenile oceanic crust, probably in a back-arc setting, followed by southward subduction, island arc magmatism and simultaneous diapiric ascent of TTG bodies in the Marowijne Greenstone Belt. Subsequently turbidites were deposited offshore and, finally, 
after a period of uplift and erosion, fluvial sediments were deposited in an intracratonic pull-apart basin formed by oblique continental collision. All supracrustal units underwent low- to medium-grade metamorphism and intensive folding. Younger plutons of two-mica-granite intruded diapirically into the turbiditic sediments.

The second phase is marked by an important rifting event in the Guiana Shield triggered by asthenospheric upwelling, which might have led to the opening of a triple-junction of rift valleys at the Bakhuis-Coeroeni-Kanuku junction, which became filled with volcanic and sedimentary deposits and underwent LP-HT high-grade metamorphism between 2.07 and 2.05 Ga. In the deepest part in the Bakhuis Granulite Belt even UHT conditions were reached.

In the third phase between 1.99 and $1.95 \mathrm{Ga}$ continuing crustal shortening by the Trans-Amazonian Orogeny led to closure of the rifts and renewed high-grade metamorphism along an anticlockwise cooling path, further anatexis and intrusion of charnockites in the Bakhuis Granulite Belt. Outside the highgrade metamorphic belts huge amounts of felsic magma were generated, probably by basaltic underplating causing melting of the granitoid lower crust, giving rise to extensive ash-flow tuffs and shallow to slightly deeper granitoid intrusions and smaller gabbro plutons.

In an alternative scenario the Cauarane-Coeroeni Belt records northwards subduction along an active continental margin and final collision with a magmatic arc around 2.03-2.00 $\mathrm{Ga}$. The ensuing magmatic pulse around $1.98 \mathrm{Ga}$ is considered post-orogenic in this view.

After the Trans-Amazonian Orogeny the molasse-type platform cover of the Roraima Supergroup was deposited around $1.88 \mathrm{Ga}$, and two distinct Proterozoic dolerite suites intruded the basement around 1.79 and 1.5 Ga. Around 1.1-1.3 Ga the whole basement was affected by shearing and mylonitisation along NNE fault zones, accompanied by thermal rejuvenation of mineral ages in the western part of the country. This was attributed to the Grenvillian collision of Amazonia and Laurentia. Jurassic dolerite dykes marked the break-up of Gondwana and the opening of the mid-Atlantic 0cean.

\section{Acknowledgements}

The Geological and Mining Service of Suriname and the Ministry of Natural Resources of Suriname are thanked for their support in arranging fieldwork, access to the archives and supplying samples for radiometric dating. The Anton de Kom University of Suriname and its staff are thanked for their logistic support. We are grateful to the Suriname Environmental and Mining Foundation for financial and logistic support. CPRM, the Geological Survey of Brazil and the Agência Brasileira de Cooperação are thanked for financial support. EdR is grateful for the financial support of the Stichting Dr. Schürmann Foundation for his many fieldwork campaigns in the Bakhuis Granulite Belt. We gratefully acknowledge the professional drawing of the maps by Ton Markus of Kartomedia. Thanks are due to Leo Kriegsman, Phil Westerhof and an anonymous reviewer for their meticulous and helpful comments on this paper.

\section{References}

Almeida, M.E., Macambira, M.J.B., Santos, J.O.S., Do Nascimento, R.S.C. \& Paquette, J.-L., 2013. Evolução crustal do noroeste do Cráton Amazônico (Amazonas, Brasil) baseada em dados de campo, geoquímicos e geocronológicos. Anais do $13^{\circ}$ Simpósio de Geologia da Amazônia, 201-204.

Arjomandi, J., Krook, L., Bosma, W. \& de Roever, E.W.F, 1973. Geological reconnaissance of the Tibiti-Coppename area, northern Suriname. Mededelingen Geologisch Mijnbouwkundige Dienst Suriname 22: 43-57.

Avelar, V.G., Lafon, J.M. \& Delor, C., 2002. Revisão geocronológica da porção centro-norte do Estado do Amapá: Implicações geodinâmicas. In: Congresso Brasileiro de Geologia, 41. João Pessoa - PB. SBG. Anais de resumos: 291.

Avelar, V.G., Lafon, J.-M., Delor, C., Guerrot, C. \& Lahondère, D., 2003. Archean crustal remnants in the easternmost part of the Guiana Shield: $\mathrm{Pb}-\mathrm{Pb}$ and $\mathrm{Sm}-$ Nd geochronological evidence for Mesoarchean versus Neoarchean signatures. Géologie de la France 2-3-4: 83-99.

Barink, H.W., 1975. Geology of the Gonini River area, SE Suriname. Mededelingen Geologisch Mijnbouwkundige Dienst 23: 155-164.

Barreto, C.J.S., Lafon, J.-M., Da Rosa-Costa, L. \& De Lima, E.F., 2013. Vulcanismo félsico paleoproterozoico do Grupo Iricoumé, Domínio ErepecuruTrombetas, Província Amazônia Central: dados de campo, caracterização petrográfica e geocronologia $\mathrm{Pb}-\mathrm{Pb}$ em zircão. Revista do Instituto de Geociências - USP 13: 47-72.

Barreto, C.J.S., Lafon, J.-M., Da Rosa-Costa, L. \& De Lima, E.F., 2014. Palaeoproterozoic ( $\sim 1.89 \mathrm{Ga})$ felsic volcanism of the Iricoumé Group, Guyana Shield, South America: geochemical and Sm-Nd isotopic constraints on sources and tectonic environment. International Geology Review 56: 1332-1356.

Barron, C.N., 1965. Geology of parts of the Corentyne and Berbice Rivers. Records Geological Survey of British Guiana 3: 3-9.

Barron, C.N., 1969. Notes on the stratigraphy of Guyana. Proceedings Seventh Guiana Geological Conference, Paramaribo, 1966. Records Geological Survey Guyana 6 II: 1-28.

Barron, C.N. 1980. Exploration characteristics of the Muri Mountains Alkaline Complex, Guyana-Brasil border. Unpublished report, 3 pp.

Barron, C.N., 1981. A short account of the Muri alkaline complex, Southeast Guyana. Unpublished report, $7 \mathrm{pp}$.

Berrangé, J.P., 1977. The geology of southern Guyana, South America. Institute of Geological Sciences, Overseas Division (London). Memoir 4: 112 pp.

Beyer, S.R, Hiatt, E.E., Kyser, K., Drever, G.L. \& Marlatt, J., 2015. Stratigraphy, diagenesis and geological evolution of the Paleoproterozoic Roraima Basin, Guyana: Links to tectonic events on the Amazon Craton and assessment for uranium mineralization potential. Precambrian Research 267: 227-249.

Bispo-Santos, F., D'Agrella-Filho, M.S., Janikian, L., Reis, N.J., Trindade, R.I.F. \& Reis, M.A.A.A., 2014. Towards Columbia: Paleomagnetism of 1980-1960 Ma Surumu volcanic rocks, Northern Amazonian Craton. Precambrian Research 244: $123-138$. 
Bisschops, J.H., 1969. The Roraima Formation in Surinam. 7th Guinana Geological Conference, Verhandelingen Koninklijk. Nederlands Geologisch Mijnbouwkundig Genootschap 27: 109-118.

Bleys, C., 1951. Kaartblad D7. Jaarverslag van de Geologisch Mijnbouwkundige Dienst over het jaar 1950: 34-49.

Bonilla-Pérez, A., Frantz, J.C., Charão-Marques, J., Cramer, T., FrancoVictoria, J.A., Mulocher, E. \& Amaya-Perea, Z., 2013. Petrografía, geoquímica y geocronología del Granito de Parguaza en Colombia. Boletín de Geología 35: 83-104.

Bosma, W., 1969. The Lada Soela Manganese deposits. Mededelingen Geologisch Mijnbouwkundige Dienst Suriname 20: 181-191.

Bosma, W., 1971. Geological reconnaissance in the Dalbana Creek area (Corantijn, western Suriname). Mededelingen Geologisch Mijnbouwkundige Dienst Suriname 21: 101-120.

Bosma, W., 1973a. The Tapajé Creek itabiritic and lateritic iron deposits. Mededelingen Geologisch Mijnbouwkundige Dienst Suriname 212: 125-132.

Bosma, W., 1973b. Nickel and copper contents of the Awalapé Gabbro. Mededelingen Geologisch Mijnbouwkundige Dienst Suriname 22: 133-136.

Bosma, W. \& De Roever, E.W.F., 1975. Results of recent geological studies in Suriname. Mededelingen Geologisch Mijnbouwkundige Dienst 23: 9-25.

Bosma, W. \& Groeneweg, W., 1973. Review of the stratigraphy of Suriname. Mededelingen Geologisch Mijnbouwkundige Dienst Suriname 22: 17-41.

Bosma, W. \& Lokhorst, A., 1975. Geophysical, geological and geochemical characteristics of some De Goeje-type gabbroic bodies. Mededelingen Geologisch Mijnbouwkundige Dienst Suriname 23: 176-193.

Bosma, W., Maas, K. \& De Roever, E.W.F., 1980. Petrogenesis of the gabbroicultramafic bodies in the northern Guiana Shield (Suriname). Unpublished ZW0/WOTR0 report W75-197, 65 pp.

Bosma, W., Kroonenberg, S.B., Maas, K. \& De Roever, E.W.F., 1983. Igneous and metamorphic complexes of the Guiana shield in Suriname. Geologie en Mijnbouw 62: 241-254.

Bosma, W., Kroonenberg, S.B., van Lissa, R., Maas, K. \& de Roever, E.W.F., 1984. Explanation to the Geological map of Suriname 1:500,000. Mededelingen Geologisch Mijnbouwkundige Dienst van Suriname 27: 31-82.

Brinck, J.W., 1955. Goudafzettingen in Suriname (Gold deposits in Suriname). Thesis Leiden. Leidse Geologische Mededelingen 21: 1-246.

Choubert, B., 1960. Les granites précambriens des Guyanes et leur origine probable. Mémoire Service de la Carte Géologique de France, Département Guyane (Paris): $176 \mathrm{pp}$.

Choubert, B., 1974. Le Précambrien des Guyanes. Mémoires BRGM 81: 213.

Cohen, A. \& Van der Eijk, J., 1953. Klassificatie en ontstaan van savannen in Suriname. Geologie en Mijnbouw 15: 202-214.

Cordani, U.G. \& Sato, K., 1999. Crustal evolution of the South American Platform, based on Nd isotopic systematics on granitoid rocks. Episodes 22(3): 167-173.

Cordani, U.G. \& Teixeira, W., 2007. Proterozoic accretionary belts in the Amazonian Craton. In: Hatcher R.D. et al. (eds): 4-D framework of continental crust. Geological Society of America Memoir 200: 297-320.

Cordani, U.G., Sato, K., Teixeira, W., Tassinari, C.C.G. \& Basei, M.A.S., 2000. Crustal evolution of the South American Platform. In: Cordani U.G., Milani E.J., Thomas Filho A. \& Campos D.A. (eds): Tectonic evolution of South America, 31st International Geological Congress, Rio de Janeiro, Brazil: 19-40.

Cordani, U.G., Fraga, L.M., Reis, N., Tassinari, C.C.G. \& Brito-Neves, B.B., 2010. On the origin and tectonic significance of the intra-plate events of
Grenvillian-type age in South America: A discussion. Journal of South American Earth Sciences 29: 143-159.

Cox, D.P., Wynn, J.C., Sidder, G.B. \& Page, N.J., 1993. Geology of the Venezuelan Guayana Shield. In: U.S. Geological Survey and Corporación Venezolana de Guayana, Técnica Minera, C.A. (eds): Geology and mineral resource assessment of the Venezuelan Guayana Shield. U.S. Geological Survey Bulletin 2062: 9-15.

Dahlberg, E.H., 1975. Lithostratigraphical correlation of granulite-facies rocks of the Guiana Shield. Mededelingen Geologisch Mijnbouwkundige Dienst Suriname 23: 26-33. Also published (1976) in Memorias 2do Congreso Latinoamericano de Geología, Caracas, Boletín de Geología, Publicación Especial No. 7: 665-673.

Dall'Agnol, R., Costi, H.T., Leite, A.A.S., Magalhães, M.S. \& Teixeira, N.P., 1999. Rapakivi granites from Brazil and adjacent areas. Precambrian Research 95: 9-39.

Daoust, C., Voicu, G., Brisson, H. \& Gauthier, M., 2011. Geological setting of the Paleoproterozoic Rosebel gold district, Guiana Shield, Suriname. Journal of South American Earth Sciences 32: 222-245.

D'Audretsch, F.C., 1957. D7 Blad Kabel. geologische kaart 1:100.000. Geologisch Mijnbouwkundige Dienst (Paramaribo): $58 \mathrm{pp.}$

Deckart, K., Bertrand, H. \& Liégeois, J.-P., 2005. Geochemistry and Sr, Nd, Pb isotopic composition of the Central Atlantic Magmatic Province (CAMP) in Guyana and Guinea. Lithos 82: 289-314.

Delor, C., Lahondère, D., Egal, E., Lafon, J.M., Cocherie, A., Guerrot, C. \& de Avelar, V., 2003a. Transamazonian crustal growth and reworking as revealed by the 1:500,000-scale geological map of French Guiana. Géologie de la France 2003 2-3-4: 5-57.

Delor, C., de Roever, E.W.F, Lafon, J.-M., Lahondère, D., Rossi, P., Cocherie, A. \& Potrel, A., 2003b. The Bakhuis ultra-high-temperature granulite belt (Suriname): II. Implications for the late Transamazonian crustal stretching in a revised Guiana Shield framework. Géologie de la France 2-3-4: 207-230.

Den Hengst, P., 1975. The Upper Saramacca chromite. Mededelingen Geologisch Mijnbouwkundige Dienst Suriname 23: 244-249.

De Roever, E.W.F., 1975. Provisional lithologic framework of the Falawatra Group, W. Suriname. Geologisch Mijnbouwkundige Dienst Suriname Mededeling 23: 34-44. Also in: Memoria 2do Congreso Latinoamericano de Geología, Boletín Geológico (Caracas), Publicación Especial no. 7, 1976: 637-648.

De Roever, E.W.F., 1975. Geology of the Central part of the Bakhuis Mountains (W Suriname). Mededelingen Geologisch Mijnbouwkundige Dienst Suriname 23: 65-101.

De Roever, E.W.F., 2014. Geology of Suriname: Main characteristics and some new aspects. Memorias Geological Map of South America Workshop, Villa de Leyva, Colombia: 26, 289-310.

De Roever, E.W.F. \& Bosma, W., 1975. Precambrian magmatism and regional metamorphism in Suriname. Anais Décima Conferência Geologica Interguianas, Belém: 123-163.

De Roever, E.W.F., Kieft, C., Murray, E.E., Klein, E. \& Drucker, W.H., 1976. Surinamite, a new Mg-Al silicate from the Bakhuis Mountains, Suriname. American Mineralogist 61: 332-333.

De Roever, E.W.F., Lafon, J.-M., Delor, C., Rossi, P., Cocherie, A., Guerrot, C. \& Potrel, A., 2003a. The Bakhuis ultra-high temperature granulite belt: I Petrological and geochronological evidence for a counterclockwise P-T path at 2.07-2.05 Ga. Géologie de la France 2003 2-3-4: 175-205. 
De Roever, E.W.F., Kroonenberg, S.B., Delor, C. \& Phillips, D., 2003b. The Käyser dolerite, a Mesoproterozoic alkaline dyke suite from Suriname. Géologie de la France 2003, 2-3-4: 161-174.

De Roever, E.W.F., Lafon, J.-M., Delor, C., Cocherie, A. \& Guerrot, C., 2015. Orosirian magmatism and metamorphism in Suriname: new geochronological constraints. Contribuições a Geologia da Amazônia 9: 359-372.

De Roever, E.W.F., Lafon, J.-M., Delor, C. \& Guerrot, C., 2010. Orosirian magmatism and metamorphism in Suriname: new geochronological constraints. Abstract 45th Congresso Brasileiro de Geologia, Belem: 1 p.

De Vletter, D.R., 1984. Synthesis of the Precambrian of Suriname and review of some outstanding problems. In: De Vletter, D.R. (ed.): Mededelingen Geologisch Mijnbouwkundige Dienst Suriname 27: 11-30.

De Vletter, D.R. \& Kroonenberg, S.B., 1987. The granitoid-volcanic complex of Suriname. IGCP-204 Precambrian Evolution of the Amazon Region. Final meeting of the working group, extended abstracts (Carajás, Brazil): 5564.

De Vletter, D.R., Aleva, G.J.J. \& Kroonenberg, S.B., 1998. Research into the Precambrian of Suriname. In: Wong Th.E. et al. (eds): The history of earth sciences in Suriname. Royal Netherlands Academy of Science, Netherlands Institute of Applied Geosciences: 15-63.

Doeve, G., 1957. Voorstel tot enkele wijzigingen in de stratigrafie van Suriname. Geologisch Mijnbouwkundige Dienst Suriname, Jaarboek 1955: 110-113.

Dreher, A.M., Fraga, L.M., Ragatky, D., Grazziotin, H. \& Reis, N.J., 2009. 0 Grupo Cauarane na Folha Vila De Tepequém, Roraima. Simpósio de Geologia da Amazônia, XI, Manaus, Amazonas: 3 pp.

Fozzard, P., 1986. Mineral exploration for phosphate, rare earths, base metals and gold. Final Report. DP/GUY/NR78/001, United Nations Revolving Fund of Natural Resources Exploration: $230 \mathrm{pp}$.

Fraga, L.M.B. \& Dreher, A.M., 2010. Suíte Pedra Pintada. In: CPRM (ed.): Programa Geologia do Brasil. Programa Cartografia da Amazônia. Geologia e Recursos Minerais da Folha Vila de Tepequém, NA.20-X-A-III. Escala 1:100.000.CPRM, Superintendência Regional de Manaus, Estado de Roraima: p. 96-106, CD-Rom.

Fraga, L.M., Reis, N.J., Dall'Agnol, R. \& Armstrong, R., 2008. CauaraneCoeroene belt - the tectonic southern limit of the preserved rhyacian crustal domain in the Guyana shield, northern Amazonian craton. 33th International Geological Congress 0slo, Abstract AMS-07.

Fraga, L.M., Reis, N.J. \& Dall'Agnol, R., 2009a. The Cauarane-Coeroene belt, the main tectonic feature of the central Guyana Shield, northern Amazonian Craton. SBG Núcleo Norte, Simpósio de Geologia da Amazônia 11, Manaus, Expanded Abstract: 3 pp.

Fraga, L.M., Macambira, M.J.B., Dall'Agnol, R. \& Costa, J.B.S., 2009b. 1.94$1.93 \mathrm{Ga}$ charnockitic magmatism from the central part of the Guiana Shield, Roraima, Brazil: single zircon evaporation data and tectonic implications. Journal of South American Earth Sciences 27: 247-257.

Fraga, L.M., Dreher, A.M., Grazziottin, H. \& Reis, N.J., 2011. Suíte Trairão Arco Magmático de 2,03-2,04 Ga, na parte norte do Craton Amazônico. $12^{\circ}$ Simpósio de Geologia da Amazônia, Boa Vista, Roraima: 1-4.

Gaudette, H.E., Hurley, P.M., Espejo, A. \& Dahlberg, E.H., 1978. Older Guiana basement south of the Imataca Complex in Venezuela and in Suriname. Geological Society of America Bulletin 89: 1290-1294.

Gibbs, A.K., 1980. Geology of the Barama-Mazaruni Supergroup of Guyana. Ph.D. thesis, Harvard University (Cambridge, MA): 385 pp.
Gibbs, A.K. \& Barron, C.N., 1983. The Guiana Shield reviewed. Episodes June: 7-14.

Gibbs, A.K. \& Barron, C.N., 1993. Geology of the Guiana shield. Oxford University Press (0xford): $246 \mathrm{pp}$.

GMD, 1977. Geological Map of Suriname 1:500,000. Geologisch Mijnbouwkundige Dienst Suriname (Paramaribo).

Gómez Tapias, J., 2014. Memorias Geological Map of South America Workshop, Villa de Leyva - Colombia 21-26 July, 2014: 488 pp.

Groeneweg, W., 1969. Geology of the Boven-Tapanahony area. Mededelingen Geologisch Mijnbouwkundige Dienst 20: 25-32.

Groeneweg, W., 1971. The Weko Soela Copper deposits. Mededelingen Geologisch Mijnbouwkundige Dienst Suriname 21: 159-162.

Hackley, P.C., Urbani, F., Karlsen, A.W. \& Garrity, C.P., 2005. Geologic shaded relief map of Venezuela. USGS 0pen File Report (Hackley): 2005-1038.

Harley, S.L., 1989. The origins of granulites: a metamorphic perspective. Geological Magazine 126: 215-247.

Haug, G.M.W., 1966. Verslag van het veldwerk in het stroomgebied van de Paloemeu. Geologisch Mijnbouwkundige Dienst Suriname, intern rapport.

Hildebrand, R.S., Buchwaldt, R. \& Bowring, S.A., 2014. On the allochthonous nature of auriferous greenstones, Guayana shield, Venezuela. Gondwana Research 26: 1129-1140.

Hoffman, P.F., 1991 Did the breakout of Laurentia turn Gondwanaland insideout? Science 252: 1409-1412.

Ho Len Fat, A.G., 1975. Geology of the Pikien Rio-Beneden Tapanahony area (E. Suriname). Mededelingen Geologisch Mijnbouwkundige Dienst Suriname 23: 165-175.

Holtrop, J.F., 1962. De mangaanafzettingen van het Guiana Schild. Mededelingen Geologisch Mijnbouwkundige Dienst Suriname 13: 514 pp.

Holtrop, J.F., 1969. Information on the granitoid rocks of Surinam, South America. Geological Society of America Bulletin 80: 2237-2252.

Hurley, P.M., de Almeida, F.F.M., Melcher, G.C., Cordani, U.G., Rand, J.R., Kawashita, K., Vandoros, P., Pinson, W.H. \& Fairbairn, H.W., 1967. Test of continental drift by comparison of radiometric ages. Science 157: 495-500.

Ibáñez-Mejia, M., Ruiz, J., Valencia, V.A., Cardona, A., Gehrels, G.E. \& Mora, A.R., 2011. The Putumayo Orogen of Amazonia and its implications for Rodinia reconstructions: New U-Pb geochronological insights into the Proterozoic tectonic evolution of northwestern South America. Precambrian Research 191: 58-77.

Issler, R.S., De Lima, R.M.G. \& Montalvão, G.G., 1975. Magnetismo alcalino no craton Guianes, in Anais Décima Conferência Geológica Interguianas, Belém do Para, Brazil (1975): 103-122.

Klaver, M., De Roever, E.W.F., Nanne, J.A.M., Mason, P.R.D. \& Davies, G.R., 2015. Charnockites and UHT metamorphism in the Bakhuis Granulite Belt, western Suriname: Evidence for two separate UHT events. Precambrian Research 262: 1-19.

Klaver, M., de Roever, E.W.F., Thijssen, A.C.D., Bleeker, W., Söderlund, U., Chamberlain, K., Ernst, R., Berndt, J. \& Zeh, A., 2016. Mafic magmatism in the Bakhuis Granulite Belt (western Suriname): relationship with charnockite magmatism and UHT metamorphism. http://dx.doi.org/ 10.1080/11035897.2015.1061591. in press.

Klein, E.L., Almeida, M.E. \& Rosa-Costa, M.L., 2012. The 1.89-1.87 Ga Uatumã Silicic Large Igneous Province, northern South America. http://www. largeigneousprovinces.org, November 2012. 
Kroonenberg, S.B., 1975. Geology of the Sisa Creek area, SW Suriname. Mededelingen Geologisch Dienst Suriname 23: 102-125.

Kroonenberg, S.B., 1976. Amphibolite facies and granulite facies metamorphism in the Coeroeni Lucie area, southwestern Surinam. PhD Thesis, University of Amsterdam. Mededelingen Geologisch. Mijnbouwkundige Dienst Suriname 25: 101-289.

Kroonenberg, S.B., 1977. Petrography of the copper-bearing rocks from Weko Soela, boven-Tapanahony, Suriname. Geologisch Mijnbouwkundige Dienst Suriname, internal report: $7 \mathrm{pp}$.

Kroonenberg, S.B., 1978. Precambrian paleosols at the base of the Roraima Formation in Surinam. Geologie en Mijnbouw 57: 445-450.

Kroonenberg, S.B., 1982. A Grenvillian granulite belt in the Colombian Andes and its relation to the Guiana Shield. Geologie en Mijnbouw 61: 325-333.

Kroonenberg, S.B., 1994. De Nickerie orogenese in het Precambrium van Suriname. In: van der Steen L. (ed.): Recente geologische en mijnbouwkundige ontwikkelingen in Suriname. Natuurwetenschappelijke Studiekring Caraïbisch gebied (Amsterdam): 41-53.

Kroonenberg, S.B., 2014: Geological evolution of the Amazonian Craton: Forget about geochronological provinces. Memorias Geological Map of South America Workshop, Villa de Leyva, Colombia: 22, 109-131.

Kroonenberg, S.B. \& De Roever, E.W.F., 2010. Geological evolution of the Amazonian Craton. In: Hoorn C. \& Wesselingh F.P. (eds): Amazonia, Landscape and Species Evolution. Blackwell Publishing (Chichester): 7-28.

Kroonenberg, S.B. \& Melitz, P.J., 1983. Summit levels, bedrock control and the etchplain concept in the basement of Suriname. Geologie en Mijnbouw 62: 389-399.

Kroonenberg, S.B. \&. Reeves, C.V., 2012. Geology and petroleum potential, Vaupés-Amazonas Basin, Colombia. Petroleum Geology of Colombia, 15. Universidad EAFIT (Medellín): $92 \mathrm{pp}$.

Lafon, J.-M., 2013. Geocronologia $\mathrm{Pb}-\mathrm{Pb}$ em zircão de rochas magmáticas da Folha Tumucumaque SIG América do Sul. Relatório Técnico Instituto de Geociências, Universidade Federal do Pará (Belém): 17 pp.

Ledru, P., Johan, V., Milési, J.P. \& Tegyey, M., 1994 Markers of the last stages of the Paleoproterozoic collision: evidence for a 2 Ga continent involving Circum-South Atlantic provinces. Precambrian Research 69: 169-191.

Loemban Tobing, D.P., 1969. Geology of the Avanavero area in Western Surinam. Proceedings of the 7th Guiana Geological Conference, Paramaribo, 1966. Verhandelingen van het Koninklijk Nederlands Geologisch Mijnbouwkundig Genootschap 27: 33-48.

Maas, K., 1979. Nota betreffende een overzicht, alsmede een tentatieve interpretatie van het Precambrium van Suriname. Geologisch Mijnbouwkundige Dienst Suriname, internal report: $23 \mathrm{pp}$.

Maas, K. \& Van der Lingen, G.J., 1975. Geology of the Sipaliwini Savannah area, South Suriname. Mededelingen Geologisch Mijnbouwkundige Dienst Suriname 23: $126-115$.

Marques, S.N.S., Souza, V.S., Dantas, E.L., Valério, C.S., \& Do Nascimento, R.S.C., 2014. Contributions to the petrography, geochemistry and geochronology (U-Pb and Sm-Nd) of the Paleoproterozoic effusive rocks from Iricoumé Group, Amazonian Craton, Brazil. Brazilian Journal of Geology 44: 121138.

McReath, I. \& Faraco, M.T., 2006. Paleoproterozoic greenstone-granite belts in northern Brazil and the Former Guyana shield - West-African province. Geologia USP, Série Científica São Paulo 5(2): 49-63.
Milési, J.P., Egal, E., Ledru, P., Vernhet, Y., Thiéblemont, D., Cocherie, A., Tegyey, M., Martel-Jantin, B. \& Lagny, P., 1995. Les minéralisations du Nord de la Guyane française dans leur cadre géologique. Chronique de la recherche minière 518: 5-58.

Montagne, D.G., 1964. An interesting pegmatite deposit in northeastern Surinam. Geologie en Mijnbouw 43: 360-374.

Montalvão, R.M.G., 1975. Grupo Uatumã no Craton Guianês. Anais Décima Conferência Geólogica Interguianas (Belém): 286-339.

Nadeau, S., 2014. Guyana Geological timescale. Guyana Geological and Mining Commission: $1 \mathrm{p}$.

Nadeau, S., Chen, W., Reece, J., Lachhman, D., Ault, R., Faraco, M.T.L., Fraga, L.M., Reis, N.J. \& Betiollo, L.M., 2013. Guyana: the Lost Hadean crust of South America? Brazilian Journal of Geology 43: 601-606.

Naipal, R. \& Kroonenberg, S.B., 2016. Provenance signals in metaturbidites of the Paleoproterozoic greenstone belt of the Guiana Shield in Suriname. Netherlands Journal of Geosciences. doi:10.1017/njg.2016.9.

Nomade, S., Théveniaut, H., Chen, Y., Pouclet, A. \& Rigollet, C., 2000. Paleomagnetic study of French Guyana Early Jurassic dolerites: hypothesis of a multistage magmatic event. Earth and Planetary Science Letters 184: 155168.

Nomade, S., Chen, Y., Pouclet, A., Féraud, G., Théveniaut, H., Daoud., B.Y., Vidal, M. \& Rigollet, C., 2003. The Guiana and West-African Shield Paleoproterozoic grouping: new paleomagnetic data for French Guiana and Ivory Coast. Geophysical Journal International 154: 677-694.

Nomade, S., Knight, K.B., Beutel, E., Renne, P.R., Verati, C., Féraud, G., Marzoli, A., Youbi, N. \& Bertrand, H., 2007. Chronology of the Central Atlantic Magmatic Province: Implications for the Central Atlantic rifting processes and the Triassic-Jurassic biotic crisis. Palaeogeography, Palaeoclimatology, Palaeoecology 244: 326-344.

Norcross, C., Davis, D.W., Spooner, E.T.C. \& Rust, A., 2000. U-Pb and $\mathrm{Pb}-$ $\mathrm{Pb}$ age constraints on Paleoproterozoic magmatism, deformation and gold mineralization in the Omai area, Guyana Shield. Precambrian Research 102: 69-86.

O'Herne, L., 1969a. A new interpretation of the stratigraphy of Surinam. Mededelingen Geologisch Mijnbouwkundige Dienst Suriname 20: 9-12.

O'Herne, L., 1969b. A photogeological study of the basal complex of Suriname. Mededelingen Geologisch Mijnbouwkundige Dienst Suriname 20: 53149.

Oosterbaan, W.E., 1975. The Adampada lateritic nickel deposit. Mededelingen Geologisch Mijnbouwkundige Dienst Suriname 23: 206-213.

Pearce, J.A., Harris, N.B.W. \& Tindle, A.G., 1984. Trace element discrimination diagrams for the tectonic interpretation of granitic rocks. Journal of Petrology 25: 956-983.

Pierosan, R., Lima, E.F., Nardi, L.V.S., DeCampo, C.P., Neto, A.C.B., Ferron, J.M.T.M. \& Prado, M., 2011. Paleoproterozoic (<1.88 Ga) felsic volcanism of the Iricoumé Group in the Pitinga Mining District area, Amazonian Craton, Brazil: insights in ancient volcanic processes from field and petrologic data. Anais da Academia Brasileira de Ciências 83: 921-937.

Premoli, C. \& Kroonenberg, S.B., 1984. Radioactive mineral potential of carbonatites in western parts of the South American shields. In: Geology and Metallogenesis of uranium deposits in South America. Proceedings of Working Group Meeting, San Luis, Argentina, 1981. International Atomic Energy Agency STI/PUB/641: 245-268. 
Priem, H.N.A., Hebeda, E.H., Boelrijk, N.A.I.M., Verschure, R.H. \& Verdurmen, E.A.Th., 1968. Isotopic age determination on Surinam rocks, 4. Ages of basement rocks in north-western Surinam and of the Roraima Tuff at Tafelberg. Geologie en Mijnbouw 47: 191-196.

Priem, H.N.A., Boelrijk, N.A.I.M., Hebeda, E.H., Verdurmen, E.A.Th. \& Verschure, R.H., 1971. Isotopic ages of the Trans-Amazonian felsicic magmatism and the Nickerie Episode in the Precambrian basement of Surinam, South America. Geological Society of America Bulletin 82: 1667-1680.

Priem, H.N.A., Boelrijk, N.A.I.M., Hebeda, E.H., Verdurmen, E.A.Th. \& Verschure, R.H., 1973. Age of the Precambrian Roraima Formation in northeastern South America: Evidence from isotopic dating of Roraima pyroclastic volcanic rocks in Suriname. Geological Society of America Bulletin 84: 16771684.

Priem, H.N.A., Boelrijk, N.A.I.M., Hebeda, E.H, Kroonenberg, S.B., Verdurmen, E.A.Th. \& Verschure, R.H., 1977. Isotopic ages of the high-grade metamorphic Coeroeni Group, SW Suriname. Geologie en Mijnbouw 56: 155-160.

Priem, H.N.A., Boelrijk, N.A.I.M., Hebeda, E.H., Kuyper, R.P., De Roever, E.W.F., Verdurmen, E.A.Th., Verschure, R.H. \& Wielens, J.B., 1978. How old are the supposedly Archean charnockitic granulites in the Guyana Shield basement of western Suriname (South America)? USGS 0pen File report 78701: 341-343.

Ramgrab, G.E. \& Santos, J.O.S., 1974. 0 grupo Uatumã. Anais do $28^{\circ}$ Congresso Brasileiro de Geologia: 87-94.

Reis, N.J., Pinheiro, S. da S., Costi, H.T. \& Costa, J.B.S., 1990. A Cobertura sedimentar Proterozóica Média do Supergrupo Roraima no Norte do Estado de Roraima, Brasil: Atribuições aos seus Sistemas Deposicionais e Esquema Evolutivo da sua Borda Meridional. Anais Congresso Brasileiro de Geologia 36: 66-81.

Reis, N.J., De Faria, M.S.G, Fraga, L.M. \& Haddad, R.C., 2000. Orosirian calcalkaline volcanism and the Orocaima event in the Northern Amazônian Craton, Eastern Roraima State, Brazil. Revista Brasileira de Geociências 30: 380383.

Reis, N.J., Fraga, L.M., de Faria, M.S.G. \& Almeida, M.E., 2003. Geologia do Estado de Roraima, Brasil. Géologie de la France 2003 2-3-4: 121-134.

Reis, N.J., Faria, M.S.G., Almeida, M.E. \& Oliveira, M.A., 2004. Folhas NA.20-Boa Vista e NB.20-Roraima. In: Schobbenhaus, C., Gonçalves, J.H., Santos, J.0.S., Abram, M.B., Leão Neto, R., Matos, G.M.M., Vidotti, R.M., Ramos, M.A.B. \& Jesus, J.D.A. de (eds): Carta Geológica do Brasil ao Milionésimo, Sistema de Informações Geográficas - SIG. Programa Geologia do Brasil. CPRM, Brasília. Edição 2004. CD-Rom.

Reis, N.J., Dreher, A., Fraga, L.M., Scandolara, J.E. \& Betiollo, L., 2009. Serra Tepequém, um possível remanescente de uma caldeira vulcânica paleoproterozóica - Estudos preliminares. In: Sociedade Brasileira de Geologia, Núcleo Norte, Anais Simposio Geolôgico Amazônico, Manaus, 11: 175-195.

Reis, N.J., Teixeira, W., Hamilton, M.A., Bispo-Santos, F., Almeida, M.E. \& D'Agrella-Filho, M.S., 2013. Avanavero mafic magmatism, a late Paleoproterozoic LIP in the Guiana Shield, Amazonian Craton: U-Pb ID-TIMS baddeleyite, geochemical and paleomagnetic evidence. Lithos 174: 175-195.

Reis, N.J., Fraga, L.M.B. \& Almeida, M.E., 2014. Arcabouço Geológico. In: Holanda, J.L.R., Marmos, J.L. \& Maia, M.A.M. (org.): Geodiversidade do estado de Roraima, CPRM: 17-32.

Rodríguez, G., Sepúlveda, J., Ramírez, C., Ortiz, F.H., Ramos, K., Bermúdez, J.G. \& Sierra, M.I., 2011. Unidades, petrografía y composición química del
Complejo Migmatítico de Mitú en los alrededores de Mitú. Boletín de Geología 33: $27-42$.

Rosa-Costa, L.T., Ricci, P.S.F., Lafon, J.-M., Vasquez, M.L., Carvalho, J.M.A., Klein, E.L. \& Macambira, E.M.B., 2003. Geology and geochronology of Archean and Paleoproterozoic domains of southwestern Amapá and northwestern Pará, Brazil, southeastern Guiana shield. Géologie de la France 2-3-4: 101-120.

Rosa-Costa, L., Lafon, J.M. \& Delor, C., 2006. Zircon geochronology and Sm-Nd isotopic study: further constraints for the Archean and Paleoproterozoic geodynamical evolution of the southeastern Guiana Shield, north of Amazonian Craton, Brazil. Gondwana Research 10: 277-300.

Rosa-Costa, L.T., Monié, P., Lafon, J.M. \& Arnaud, N.O., 2009. ${ }^{40} \mathrm{Ar}-{ }^{39} \mathrm{Ar}$ geochronology across Archean and Paleoproterozoic terranes from southeastern Guiana Shield (north of Amazonian Craton, Brazil): Evidence for contrasting cooling histories. Journal of South American Earth Sciences 27: 113-128.

Santos, J.O.S., Hartmann, L.A., Gaudette, H.E., Groves, D.I., McNaughton, N.J. \& Fletcher, I.R., 2000. A new understanding of the provinces of the Amazon Craton based on integration of field mapping and U-Pb and Sm-Nd geochronology. Gondwana Research 3: 453-488.

Santos, J.O.S., Potter, P.E., Reis, N.J., Hartmann, L.A., Fletcher, I.R. \& McNaughton, N.J., 2003. Age, source and regional stratigraphy of the Roraima Supergroup and Roraima-like outliers in northern South America based on U-Pb geochronology. Geological Society of America Bulletin 115: 331-348.

Santos, J.O.S., Hartmann, L.A., Faria, M.S., Riker, S.R., Souza, M.M., Almeida, M.E. \& McNaughton, N.J., 2006. Compartimentação do Cráton Amazonas em províncias: avanços ocorridos no período 2000-2006. Simpósio de Geologia da Amazônia, vol. 9, Sociedade Brasileira de Geologia (Belém, Brazil): Resumos Expandidos, CD-Rom.

Santosh, M., Liu, S.J., Tsunogae, T. \& Li, J.H., 2012. Paleoproterozoic ultrahightemperature granulites in the North China Craton: Implications for tectonic models on extreme crustal metamorphism. Precambrian Research 222-223: 77-106.

Schols, H. \& Cohen, A., 1951. Geologische overzichtskaart. Geologisch Mijnbouwkundige Dienst Suriname, Jaarboek 1950: 11-17.

Schols, H. \& Cohen, A., 1953. De ontwikkeling van de geologische kaart van Suriname. Geologie en Mijnbouw 15: 142-151.

Schomburgk, $\boldsymbol{R}_{.}, 1845$, Journal of an expedition from Pirara to the Upper Corentyne and from thence to Demerara. Journal of the Royal Geographical Society 15: 1-104.

Singh, S., 1966. Geology and petrology of part of the Guiana Shield in the SouthSavanna-Rewa area of Guyana. Geological Survey of Guyana, Bulletin 37: 127 pp.

Tassinari, C.C.G, 1981. Evolução geotectônica da Província rio Negro-Juruena na região amazônica. Dissertaçao de mestrado, Instituto de Geociências, Universidade de São Paulo: 99 pp.

Tassinari, C.C.G. \& Macambira, M.J.B., 1999. Geochronological provinces of the Amazonian Craton. Episodes: 174-182.

Tassinari, C.C.G., Cordani, U.G., Nutman, A.P., van Schmus, W.R., Bettencourt, J.S. \& Taylor, P.N., 1996. Geochronological systematics on basement rocks from the Rio Negro-Juruena Province Amazonian Craton, and tectonic implications. International Geological Review 38: 161-175.

Tassinari, C.C.G., Bettencourt, J.S., Geraldes, M.C., Macambira, M.J.B. \& Lafon, J.-M., 2000. The Amazonian Craton. In: Cordani, U.G., Milani, E.J., Thomas 
Filho, A. \& Campos, D.A. (eds): Tectonic evolution of South America. 31st International Geological Congress, Rio de Janeiro, Brazil: 41-95.

Tassinari, C.C.G., Munhá, J.M.U., Teixeira, W., Nutman, A., Palacios, T., Sosa, S.C. \& Calado, B.O., 2004a. Thermochronological history of the Imataca complex, NW Amazonian Craton. Short papers IV South American Symposium on Isotope Geology: 121-123.

Tassinari, C.C.G., Munhá, J.M.U., Teixeira, W., Palacios, T., Nutman, A., Sosa, S.C., Santos, A.P. \& Calado, B.O., 2004b. The Imataca Complex, NW Amazonian Craton, Venezuela: crustal evolution and integration of geochronological and petrological cooling histories. Episodes 27: 3-12.

Tohver, E., Teixeira, W., van der Pluijm, B., Geraldes, M.C., Bettencourt, J.C. \& Rizzotto, G., 2006. Restored transect across the exhumed Grenville orogen of Laurentia and Amazonia, with implications for crustal architecture. Geology 34: 669-672.

Tong, L., Xu, Y., Cawood, P.A., Zhou, X., Chen, Y. \& Liu, Z., 2014. Anticlockwise $\mathrm{P}-\mathrm{T}$ evolution at $280 \mathrm{Ma}$ recorded from ultrahigh-temperature metapelitic granulite in the Chinese Altai orogenic belt, a possible link with the Tarim mantle plume? Journal of Asian Earth Sciences 94: 1-11.

Touret, J.L.R. \& Huizenga, J.M., 2012. Fluid-assisted granulite metamorphism: A continental journey. Gondwana Research 21: 224-235.

Valério, C.S., Macambira, M.J.B. \& Souza, V.S., 2012. Field and petrographic data of 1.90 to $1.88 \mathrm{Ga}$ I- and A-type granitoids from the central region of the Amazonian Craton, NE Amazonas State, Brazil. Revista Brasileira de Geociências 42: 690-712.

Vanderhaeghe, 0., Ledru, P., Thiéblemont, D., Egal, E., Cocherie, A., Tegyey, M. \& Milési, J.P., 1998. Contrasting mechanism of crustal growth Geodynamic evolution of the Paleoproterozoic granite-greenstone belts of French Guiana. Precambrian Research 92: 165-193.
Van Eijk, H.T.L., 1961. Preliminary geological sketch-map, sheet De Goejegebergte-H9 (69), scale 1:200,000. Geologisch Mijnbouwkundige Dienst Suriname, Jaarboek 1956-1958: 26-29.

Veenstra, E., 1983. Petrology and geochemistry of sheet Stonbroekoe, sheet 30, Suriname. Thesis, University of Amsterdam. Also in: Mededelingen Geologisch Mijnbouwkundige Dienst Suriname 26: 1-138.

Verhofstad, J., 1971. The geology of the Wilhelmina Mountains in Suriname, with special reference to the occurrence of Precambrian ash-flow tuffs. Thesis, University of Amsterdam. Mededelingen Geologisch Mijnbouwkundige Dienst Suriname 21: 9-97.

Voicu, G., Bardoux, M. \& Stevenson, R., 2001. Lithostratigraphy, geochronology and gold metallogeny in the northern Guiana Shield, South America: a review. Ore Geology Reviews 18: 211-236.

Watson, T. 2008. Volcanism and sedimentation: New insight into arc-related volcanism and sediment deposition in a synkinematic paleoproterozoic basin: Rosebel Gold Mine, northeastern Suriname. Thesis, University of North Carolina at Chapel Hill: 96 pp.

Wong, Th.E., 2014. Geological development of the coastal plain of Suriname. Memorias Geological Map of South America Workshop, Villa de Leyva, Colombia: 22-23, 164-177.

Wynn, J.C., 1993. Geophysics of the Venezuelan Guayana Shield. In: U.S. Geological Survey and Corporación Venezolana de Guayana, Técnica Minera, C.A. (eds): Geology and mineral resource assessment of the Venezuelan Guayana Shield. U.S. Geological Survey Bulletin 2062: 17-98.

Yang, N.F., 2014. The Patamacca Granite in relation to other granitoids in Suriname and the Guiana Shield. MSc thesis, University of Utrecht: 90 pp.

IJzerman, $\boldsymbol{R}$., 1931. Outline of the geology and petrology of Surinam (Dutch Guiana). Kemink \& Zoon N.V. (Utrecht): 519 pp. 